\title{
AS PROTEÍNAS DO VITELO DO NEMATOIDE ENTOMOPATOGÊNICO Heterorhabditis baujardi LPP7
}

Dissertação apresentada ao Programa de PósGraduação em Biologia da Relação PatógenoHospedeiro do Instituto de Ciências Biomédicas da Universidade de São Paulo, para a obtenção do título de Mestre em Ciências. 


\section{AS PROTEÍNAS DO VITELO DO NEMATOIDE ENTOMOPATOGÊNICO Heterorhabditis baujardi LPP7}

Dissertação apresentada ao Programa de PósGraduação em Biologia da Relação PatógenoHospedeiro do Instituto de Ciências Biomédicas da Universidade de São Paulo, para a obtenção do título de Mestre em Ciências.

Área de concentração: Biologia da Relação Patógeno-Hospedeiro

Orientador: Prof. Dr. Carlos Eduardo Winter

Versão original 
DADOS DE CATALOGAÇÃO NA PUBLICAÇÃO (CIP)

Serviço de Biblioteca e Informação Biomédica do Instituto de Ciências Biomédicas da Universidade de São Paulo

reprodução não autorizada pelo autor

Rossi, Carolina.

As proteínas do vitelo do nematoide entomopatogênio Heterorhabditis baujardi LPP7 / Carolina Rossi. -- São Paulo, 2014.

Orientador: Prof. Dr. Carlos Eduardo Winter.

Dissertação (Mestrado) - Universidade de São Paulo. Instituto de Ciências Biomédicas. Departamento de Parasitologia. Área de concentração: Biologia da Relação Patógeno-Hospedeiro. Linha de pesquisa: Biologia molecular de nematoides.

Versão do título para o inglês: The yolk proteins of the entomopathogenic nematode Heterorhabditis baujardi LPP7.

1. Nematoides entomopatogênicos 2. Heterorhabditis baujardi LPP7 3. Desenvolvimento 4. Vitelogenina 5. Gene vit-6 I. Winter, Prof. Dr. Carlos Eduardo II. Universidade de São Paulo. Instituto de Ciências Biomédicas. Programa de Pós-Graduação em Biologia da Relação Patógeno-Hospedeiro III. Título. 
Candidato(a):

Título da Dissertação:

Orientador(a):

Prof. Dr. Carlos Eduardo Winter.

A Comissão Julgadora dos trabalhos de Defesa da Dissertação de Mestrado, em sessão pública realizada a ..$/ \ldots$. considerou
( ) Aprovado(a)
( ) Reprovado(a)

Examinador(a): Assinatura:

Nome:

Instituição:

Examinador(a): Assinatura:

Nome:

Instituição:

Presidente: Assinatura:

Nome:

Instituição: 


\section{CERTIFICADO}

Certificamos que o protocolo registrado sob $n^{\circ} 039$ nas fls. 127 do livro 02 para uso de animais em experimentação, sob a responsabilidade do Prof(a) Dr(a)) Carlos Eduardo Winter, Coordenador (a) da Linha de pesquisa "Inoculação de camundongos com antígenos proteicos para geração de antissoros monoespecíficos" do qual participam o(s) Maira Rodrigues de Camargo Neves, Carolina Rossi, está de acordo com os Princípios Éticos de Experimentação Animal adotado pela Sociedade Brasileira de Ciência de Animais de Laboratório (SBCAL) e foi aprovado pela COMISSÃO DE ÉTICA NO USO DE ANIMAIS (CEUA) em 18.04.2012, com validade de 4 anos.

São Paulo, 18 de abril de 2012.
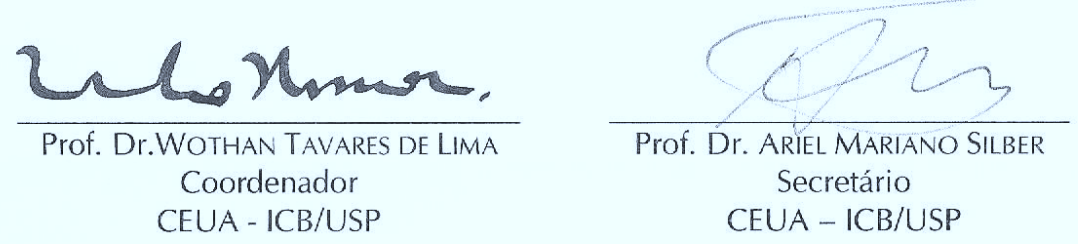
Ao meu querido e amado pai (in memorian) 


\section{AGRADECIMENTOS}

Agradeço a todos que contribuíram para a realização deste trabalho.

Ao meu orientador, Prof. Dr. Carlos Eduardo Winter, por ter me recebido e ter sido presente e atencioso todos os dias. Por todos os ensinamentos e por ser um amigo.

Aos amigos do Laboratório de Biologia Molecular de Nematoides: Maira de Camargo Neves, Camila Cristina Coelho, Marco Arantes, Manoel Aparecido Neves e Camila Pereira Soares, pelas discussões sempre proveitosas, pelas inúmeras ajudas e pela amizade tão querida. Em especial ao Manoel, pelo apoio técnico, por ser tão paciente e por sempre ter uma solução para tudo.

Aos doutores Fernando Luis Kamitani e Daniela Peres Almenara, pela minha iniciação científica e por me ensinarem com paciência e quantas vezes forem necessárias, até hoje.

Aos meus pais, Osvaldenir Rossi (in memorian) e Bernadete Kobal Quitolino Rossi, por acreditarem em mim e terem me dado o espaço necessário para seguir minha carreira e meus sonhos.

Aos meus irmãos, Rafael Rossi e Maria Isabel Rossi, por tornarem tudo mais fácil e mais bonito. E à minha cunhada e irmã, Rachel Ifanger Albrecht, pelos conselhos acadêmicos e não acadêmicos.

À minha madrinha Maria de Lourdes Quitolino, por ter tornado meus sonhos possíveis. E por ter me ensinado tanto.

Ao Oscar José Fernandes Tanner, por estar ao meu lado todos os dias, garantindo que tudo vai ficar bem. Pela ajuda direta nesta dissertação, e pela ajuda indireta, pelas conversas, conselhos, amor e segurança.

Aos meus avós, por terem me ensinado que ser honesto é mais importante que ganhar. E que para ganhar, é necessário trabalhar.

Às amigas de moradia em São Paulo: Andrea Bueno Andrade, Fabiana Maximiano da Silva e Larissa Costa Vilasboas Silva, por serem minha família durante anos e tornarem tudo mais leve e divertido.

Aos amigos do colégio e da graduação, felizmente são tantos que não consigo listar. Em especial à Michelle Konig, por ter compartilhado das minhas alegrias e agonias desde que nos conhecemos.

Aos professores do Departamento de Parasitologia do ICB-USP, pelas ótimas aulas, dis- 
cussões, ensinamentos e empréstimos de material e equipamentos. Em especial ao Prof. Dr. Arthur Gruber pelas análises de bioinformática e pela amizade. E também à Prof. Dra. Andrea Cristina Fogaça, por ter me ensinado, mesmo que por alguns meses apenas, sobre como ser uma boa professora.

Aos funcionários do Departamento de Parasitologia do ICB-USP, por estarem sempre prontos para me ajudar.

Aos colegas pós-graduandos e de I.C. do Departamento de Parasitologia do ICB-USP, pelas ajudas constantes, conversas, festas e amizade.

À Profa. Dra. Cláudia Dolinski (Universidade do Norte Fluminense), por enviar as linhagens de entomopatogênicos. E à Dra. Inês Ribeiro Machado, pelo envio do protocolo de cultivo in vitro de entomopatogênicos.

Ao Conselho Nacional de Desenvolvimento Científico e Tecnológico (CNPq) e a Fundação de Amparo à Pesquisa de São Paulo (FAPESP; auxílio proc. 10/51973-0) pelo suporte financeiro. 
Tenho a impressão de ter sido uma criança brincando à beira-mar, divertindo-me em descobrir uma pedrinha mais lisa ou uma concha mais bonita que as outras, enquanto o imenso oceano da verdade continua misterioso diante de meus olhos.

Isaac Newton

Todo poema é uma aproximação. A sua incompletude é o que o aproxima da inquietação do leitor. Este não quer que Ihe provem coisa alguma. Está farto de soluções. Eu, por mim, Ihe aumentaria as interrogações. Vocês já repararam no olhar de uma criança quando interroga? A vida, a irrequieta inquietude que ele tem? Pois bem, você Ihe dá uma resposta instantânea, definitiva, única - e verá pelos olhos dela que baixou vários risquinhos na sua consideração. 


\section{RESUMO}

ROSSI, C. As proteínas do vitelo do nematoide entomopatogênico Heterorhabditis baujardi LPP7. 2014. 75f. Dissertação (Mestrado em Biologia da Relação Patógeno-Hospedeiro) - Instituto de Ciências Biomédicas, Universidade de São Paulo, São Paulo, 2014.

Heterorhabditis é um gênero de nematoides da família Rhabditidae. São entomopatogênicos e simbiontes de bactérias do gênero Photorhabdus. Estes dois organismos associados são capazes de infectar e matar artrópodes de diferentes grupos, como insetos e carrapatos. A linhagem LPP7 de Heterorhabditis baujardi, modelo deste trabalho, foi isolada na cidade de Monte Negro (RO), Brasil. Uma das principais linhas de pesquisa em nosso laboratório é descrever e compreender como são produzidas as proteínas de vitelo em nematoides. A vitelogênese compreende o acúmulo de reservas como proteínas, lipídeos e carboidratos dentro do ovócito em crescimento. Estas reservas são produzidas no intestino e transportadas através do pseudoceloma por uma lipoproteína chamada vitelogenina que, quando internalizada nos ovócitos, recebe o nome de vitelina. Resultados obtidos para esta proteína em Caernohabditis elegans e Oscheius tipulae são utilizados neste trabalho como ponto inicial para caracterizar as vitelinas de H. baujardi LPP7. Clonamos e sequenciamos um fragmento de $800 \mathrm{pb}$ do gene vit-6 de LPP7. Sua caracterização mostrou que se trata do gene codificante do fim do polipeptídeo homólogo a VT3 de 0 . tipulae ou a YP88 de C. elegans. A análise do fragmento mostrou que o produto do seu transcrito possui $61 \%$ de identidade com a proteína VIT-6 de O. tipulae CEW1 e 46\% de identidade com VIT-6 de C. elegans. Este dado confirma que Heterorhabditis é mais próximo filogeneticamente de Oscheius do que de Caenorhabditis. Pudemos ainda purificar as proteínas de vitelo de LPP7 através de cromatografia de afinidade e de troca iônica aniônica. Quando analisadas por SDS-PAGE, as vitelogeninas de LPP7 mostram três bandas com migração e pesos moleculares próximos às vitelogeninas de O. tipulae (VT1, VT2 e VT3). No entanto, ao contrário do que foi mostrado em $O$. tipulae, onde a banda VT1 é composta por um único polipeptídeo, VT1 de LPP7 aparentemente contém um par de bandas com massas moleculares quase idênticas, como ocorre com a proteína homóloga YP170 de C. elegans. Dessa forma, sugerimos preliminarmente que a banda VT1 de H. baujardi LPP7 seja composta por dois polipeptídeos, que chamamos VT1A e VT1B.

Palavras-chave: Nematoides entomopatogênicos. Heterorhabiditis baujardi LPP7. Desenvolvimento. Vitelogenina. Gene vit-6. 


\begin{abstract}
ROSSI, C. Purification and characterization of yolk proteins of the entomopathogenic nematode Heterorhabditis baujardi LPP7. 2014. 75p. Dissertation (Masters in Biology of Host-Pathogen Interaction) - Instituto de Ciências Biomédicas, Universidade de São Paulo, São Paulo, 2014.

Heterorhabditis is a genus of nematodes belonging to the family Rhabditidae. They are entomopathogenic and associated, in a special kind of mutualism, with bacteria of the genus Photorhabdus. Together these two organisms are able to infect and kill different groups of arthropods such as insects and ticks. Heterorhabditis baujardi strain LPP7 object of this study, was isolated in Monte Negro (RO), Brazil. One of the main lines of research in our lab is to describe and understand how are produced the yolk proteins originated from the vitellogenin. The yolk reserves accumulated within the oocyte is composed of proteins, lipids and carbohydrates produced in the intestine and transported through the pseudocoelom to the growing oocyte. The transport of these substances is performed by a lipoprotein called vitellogenin that is called yolk when internalized in oocytes. Results obtained on this lipoprotein from Caernohabditis elegans and Oscheius tipulae were used in this work as a starting point to characterize the vitellins of $H$. baujardi LPP7. We have cloned and partially sequenced a fragment of $800 \mathrm{pb}$ of the vit- 6 gene from LPP7. This fragment contains a portion of a homologous to those coding for the vitellins VT3 of O. tipulae and the YP88 C. elegans polypeptides. Analysis of the putative polypeptide coded by the sequenced portion of the fragment showed that it has $61 \%$ identity to VIT-6 protein of O. tipulae CEW1 and $46 \%$ of identity to VIT-6 of C. elegans. This finding confirms that Heterorhabditis is more closely related to Oscheius than Caenorhabditis. We were able to purify, through affinity and ion exchange chromatography, the yolk polypeptides of LPP7. When analyzed by SDS-PAGE the purified proteins of LPP7 show three bands with migrations close to the vitellins of $O$. tipulae (VT1, VT2 and VT3). However, unlike what was shown in $O$. tipulae where the VT1 band is comprised of a single polypeptide, LPP7 VT1 apparently contains a pair of bands with almost identical molecular masses as occurs with the homologous vitellin of C. elegans YP170. Thus, we suggest preliminarily that the VT1 band of H. baujardi LPP7 is composed of two polypeptides that we call VT1A and VT1B
\end{abstract}

Keywords: Entomophatogenic nematodes. Heterorhabiditis baujardi LPP7. Development. Vitellogenin. vit-6 gene. 


\section{LISTA DE FIGURAS}

Figura 1.1 Estrutura filogenética do Filo Nematoda . . . . . . . . . . . . . 20

Figura 1.2 Ciclo de vida de Heterorhabditis spp . . . . . . . . . . . . . . . 23

Figura 1.3 Esquema da Endotoquia Matricida . . . . . . . . . . . . . . 24

Figura 1.4 Genes e polipeptídeos de vitelogenina de C. elegans . . . . . . . . 28

Figura 1.5 Esquema da vitelogênese em C. elegans . . . . . . . . . . . . . 28

Figura 1.6 SDS-PAGE mostrando os polipeptídeos de vitelo de O. tipulae CEW1 . 29

Figura 4.1 Ciclo de vida de H. baujardi LPP7 in vitro . . . . . . . . . . . . . . . 47

Figura 4.2 Taxa de Infectividade de H. baujardi LPP7 mantido in vitro por quatro gerações. . . . . . . . . . . . . . . . . . . 48

Figura 4.3 SDS-PAGE de verme inteiro . . . . . . . . . . . . . . 49

Figura 4.4 Purificação das vitelogeninas de H. baujardi LPP7 por cromatografia de afinidade em Con A-Sepharose. . . . . . . . . . . . . . . . 50

Figura 4.5 SDS-PAGE da purificação das bandas de VTG por cromatografia de troca iônica. ............................ 51

Figura 4.6 SDS-PAGE dos polipeptídeos de VTG separados por eletroeluição. . . . 51

Figura 4.7 Produção de antissoros monoespecíficos. . . . . . . . . . . . . . 52

Figura 4.8 Mapeamento dos contigs de RNAseq ao longo da proteína VIT-6 de

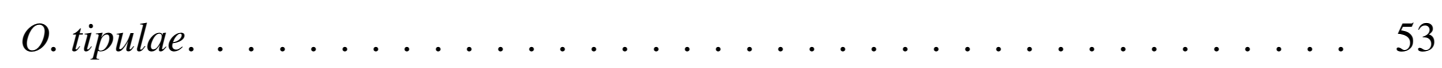

Figura 4.9 RT-PCR para amplificar fragmentos do gene vit-6 de H. baijardi LPP7. . 55

Figura 4.10 Gel de agarose $1 \%$ mostrando os fragmentos codificantes de VTG clonados e TOPO e pGEM e o fragmento codificante da proteína ribossômica L8, clonado em TOPO. . . . . . . . . . . . . . . . . . . 56

Figura 4.11 Alinhamento entre a sequência traduzida de vit-6 de LPP7 e sequências de VIT-6 de espécies filogeneticamente relacionadas. . . . . . . . . . . . . 57

Figura 5.1 Sítios de clivagem do precursor VIT-6 em diferentes espécies de rhabditídeos. ................................ 61

Figura 5.2 Relação filogenética dos nematoides Rhabditídeos . . . . . . . . . . . 62 
Figura A.1 Perfil da cromatografia de troca iônica para purificação de VTG . . . . . 73

Figura B.1 Índice de qualidade dos reads provenientes de RNAseq. . . . . . . . . . 75 


\section{LISTA DE TABELAS}

Tabela 1.1 Aplicação de NEPs no controle biológico de insetos praga. Extraída e adaptada de Almenara et al. (2012) . . . . . . . . . . . . . . . . . . . . 25

Tabela 3.1 Oligonucleotídeos iniciadores utilizados. . . . . . . . . . . . . . . 37

Tabela 3.2 Pares de oligonucleotídeos utilizados nos ensaios de RT-PCR. . . . . . . 38

Tabela 4.1 Porcentagem de identidade entre as sequências alinhadas na Figura 4.11 56 


\section{LISTA DE ABREVIATURAS E SIGLAS}

cDNA - DNA complementar ao mRNA

DNA - Ácido desoxirribunucléico

dNTPs - Desoxirribunucleosídeos trifosfatados

DTT - Ditiotreitol

EDTA - Etilenodiaminotetracetato de sódio

ESTs - Expressed Sequence Tags

$\mathbf{g}$ - Aceleração da gravidade $\left(980,665 \mathrm{~cm} / \mathrm{s}^{2}\right)$

IPTG - Isopropil-tio- $\beta$-D-galactopiranosídeo

$\mathbf{J i}$ - Juvenil Infectante

$\mathbf{k B}$ - Mil pares de bases nitrogenadas

$\mathbf{k D a}-$ Massa molecular de proteínas $=1000$ daltons

L (1-4) - Larva (1-4)

LB - Luria-Bertani

LLTPs - "Large Lipid Transfer Proteins'

$\mathbf{m} / \mathbf{v}$ - Massa por volume

MAB/mab - "male abnormal"

mRNA - RNA mensageiro

NEP - Nematoide entomopatogênico

$\mathbf{p b}$ - Pares de bases nitrogenadas

PCR - "Polymerase Chain Reaction” ; Reação em Cadeia da Polimerase

pH - - log aH+ (em soluções diluídas de ácido $\mathrm{pH}=-\log [H+])$

RNA - Ácido ribonucleico

RNAse A - Ribonuclease A pancreática

RT-PCR - PCR a partir de cDNA

SDS-PAGE - Eletroforese em gel de poliacrilamida na presença de dodecil sulfato de sódio 
SDS - Dodecil Sulfato de Sódio

SSU rRNA - RNA da subunidade menor do ribossomo

$\mathbf{T}$ - Concentração total de monômeros de acrilamida e bisacrilamida em \% $(\mathrm{m} / \mathrm{v})$

TCA - Ácido tricloroacético

TE - Tris-EDTA

TEMED - $N, N, N^{\prime}, N^{\prime}$-tetrametilenodiamina

Tm - Temperatura em que metade das moléculas de DNA encontra-se desnaturada.

Tris - Tris (hidroximetil) aminometano

$\mathbf{v} / \mathbf{v}$ - Volume por volume

VIT/vit - Vitelogenina de Nematoides

VT - Vitelina

VTG - Vitelogenina

X-gal - 5-bromo-4-cloro-3-indolil- $\beta$-D-galactopiranosídeo

YP - "Yolk Protein" 


\section{SUMÁRIO}

1. INTRODUÇÃO

$1.1 \quad$ Filo Nematoda . . . . . . . . . . . . . . . . . . . . . . . . . 19

1.2 Nematoides Entomopatogênicos do gênero Heterorhabditis . . . . . . . . . . . . 21

1.2.1 Ciclo de vida . . . . . . . . . . . . . . . . . . 21

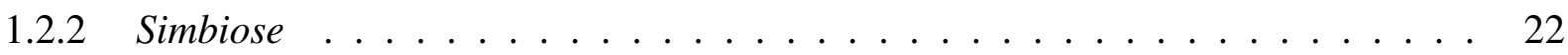

1.2.3 Controle Biológico de Insetos Praga . . . . . . . . . . . . . . . . . . . 24

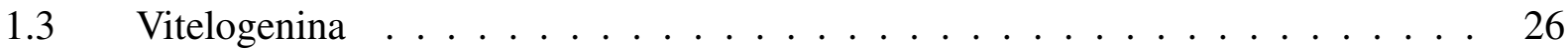

2. OBJETIVOS

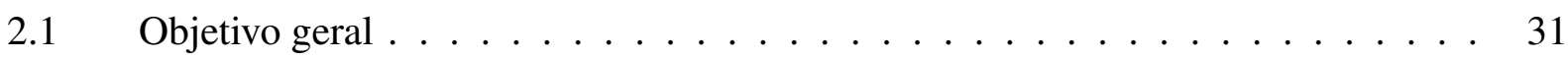

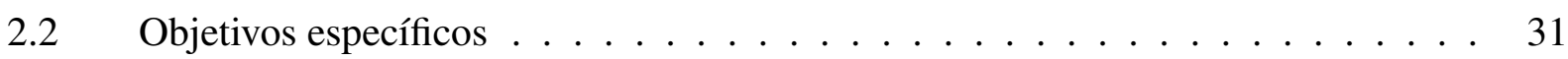

3. MATERIAL E MÉTODOS 33

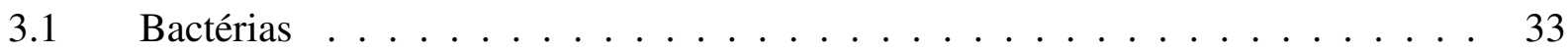

3.1.1 Linhagens de Escherichia coli utilizadas . . . . . . . . . . . . . . . 33

3.1.2 Preparação de bactérias DH5- $\alpha$ quimio-competentes . . . . . . . . . . . 33

3.1.3 Transformação de bactérias DH5- $\alpha$ quimio-competentes . . . . . . . . . . 33

3.1.4 Linhagens de Photorhabdus luminescens utilizadas . . . . . . . . . . . . . . 34

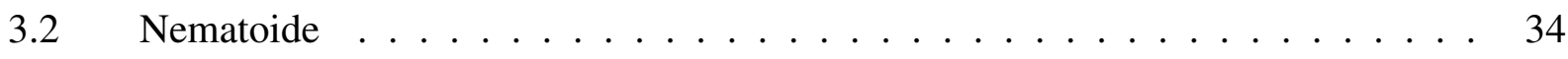

3.2.1 Linhagem de Nematoide Entomopatogênico utilizada . . . . . . . . . . . . . . . 34

3.2.2 Cultivo de Heterorhabditis baujardi LPP7 em Galleria mellonella . . . . . . . . . 34

3.2.3 Cultivo in vitro de Heterorhabditis baujardi LPP7 . . . . . . . . . . . . . . 34

3.2.4 Contagem e cálculo da Infectividade de H. baujardi LPP7 mantido in vitro . . . 35

3.3 Manipulação e Análise de Ácidos Nucleicos . . . . . . . . . . . . . . . . 35

3.3.1 Extração de RNA total de Heterorhabditis baujardi LPP7 pelo método do Tiocianato de Guanidina . . . . . . . . . . . . . . . . . . . . . 35 
3.3.2 Purificação de RNA mensageiro de Heterorhabditis baujardi LPP7 . . . . . . . . 36

3.3.3 RNAseq de Heterorhabditis baujardi LPP7 . . . . . . . . . . . . . . . . . . 36

3.3.4 Alinhamentos de sequências e produção de oligonucleotídeos . . . . . . . . . . 37

3.3.5 Produção de cDNAs de H. baujardi LPP7 e RT-PCR _ . . . . . . . . . . . . 38

3.3.6 Eletroforese de DNA em gel de agarose . . . . . . . . . . . . . . . . . 39

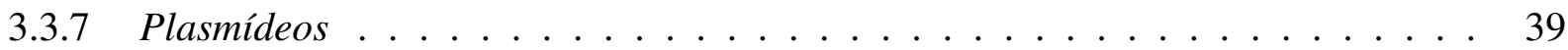

3.3.8 Clonagem de Produto de PCR . . . . . . . . . . . . . . . . . . . . . . 39

3.3.9 Purificação de Plasmídeos - Wizard $囚$ Plus SV Minipreps (Promega, Madison, Wisconsin, Estados Unidos da América) . . . . . . . . . . . . . . . . . . . . 40

3.3.10 Purificação de Plasmídeos com Cloreto de Lítio . . . . . . . . . . . . . . . . . . 40

3.3.11 Sequenciamento de DNA . . . . . . . . . . . . . . . . . . 40

3.4 Purificação e Análise de Proteínas . . . . . . . . . . . . . . . . . . 41

3.4.1 Purificação de vitelogenina . . . . . . . . . . . . . . . 41

3.4.2 Eletroforese de proteína em gel de poliacrilamida na presença de SDS (SDS-PAGE) 42

3.4.3 Eluição de peptídeos de gel de poliacrilamida . . . . . . . . . . . . . 42

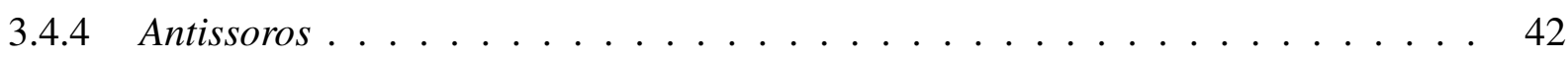

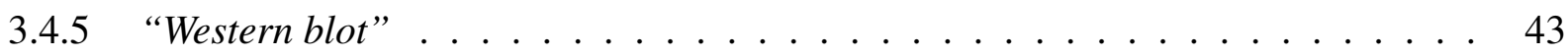

$3.5 \quad$ Lista de Soluções . . . . . . . . . . . . . . . . . . . . . . . . 43

$\begin{array}{ll}\text { 4. RESULTADOS } & 47\end{array}$

$4.1 \quad$ Cultura de nematoides em massa . . . . . . . . . . . . . . . 47

4.1.1 Manutenção da cultura de H. baujardi LPP7 in vitro . . . . . . . . . . . . . . . 47

4.1.2 Taxa de infectividade de nematoides mantidos in vitro . . . . . . . . . . . 48

4.1.3 Manutenção da especificidade da simbiose in vitro . . . . . . . . . . . . . . 48

4.2 Purificação da Vitelogenina . . . . . . . . . . . . . . . . . . . . . . 49

$4.2 .1 \quad S D S-P A G E$ de verme inteiro $\ldots \ldots \ldots \ldots$. . . . . . . . . . . . . . . . 49

$4.2 .2 \quad$ Purificação das proteínas de vitelo . . . . . . . . . . . . . . . . . . . . . . . 49 
4.2.3 Separação dos polipeptídeos de vitelogenina por eletroeluição de gel de poliacrilamida ........................ 50

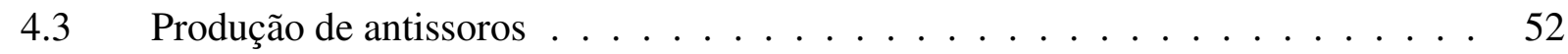

4.4 Caracterização dos genes de VTG . . . . . . . . . . . . . . . . . 53

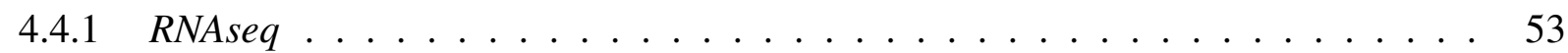

4.4.2 Produção de oligonucleotídeos a partir do RNAseq . . . . . . . . . . . . . 53

4.4.3 Alinhamento entre H. bacteriophora $e$ O. tipulae e produção de oligonucleotideos

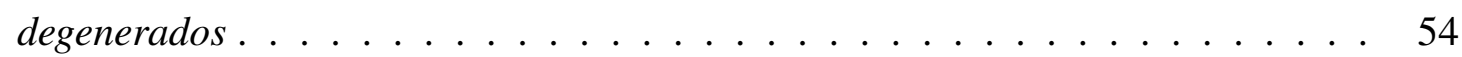

4.4.4 RT-PCR para amplificar o gene Hba-vit-6 . . . . . . . . . . . . . . . . 54

4.4.5 Clonagem e sequenciamento de fragmentos amplificados . . . . . . . . . . . 5 54

4.4.6 Caracterização do fragmento do gene vit-6 de H. baujardi LPP7 . . . . . . . . 55

5. DISCUSSÃO

$5.1 \quad$ Cultura de Nematoides Entomopatogênicos . . . . . . . . . . . . . . 59

$5.2 \quad$ Genes de Vitelogenina de Nematoides . . . . . . . . . . . . . . . . 60

$5.3 \quad$ Vitelinas de Nematoides $\ldots \ldots \ldots \ldots \ldots$

REFERÊNCIAS

APÊNDICE A - PERFIL DA CROMATOGRAFIA DE TROCA IÔNICA

APÊNDICE B - ÍNDICE DE QUALIDADE DOS READS PROVENIENTES DE

RNASEQ 


\section{INTRODUÇÃO}

\subsection{Filo Nematoda}

Os nematoides pertencem a um grande filo de metazoários com um total de espécies estimado entre 100.000 e 1.000.000 (LAMBSHEAD, 1993). Estes vermes possuem diversas estruturas em comum, como corpo alongado e cilíndrico e a presença de pseudoceloma (WOOD, 1988). No entanto, há uma diversidade enorme de estruturas associadas com biologia e hábito de vida destes animais, como ornamentação da cutícula e aparelhos bucais (LEY, 2006). Muitos dos animais conhecidos deste grupo são parasitas, e foram amplamente estudados justamente pela sua importância médica, no caso dos parasitas de seres humanos e econômica, no caso de parasitas de animais e plantas. No entanto, há uma diversidade muito grande de nematoides de vida livre, sendo o mais conhecido deles o da espécie Caernohabditis elegans. Esta espécie tem sido amplamente utilizada nos últimos anos em estudos de biologia molecular, nas áreas de neurobiologia, biologia do desenvolvimento, diferenciação sexual, entre outras.

Morfologicamente, nematoides são descritos como vermes de corpo alongado, cilíndrico e geralmente pequenos (cerca de $2 \mathrm{~mm}$ ). Porém, há espécies maiores como a Placentonema gigantissima, que mede em média 9 metros e é encontrada na placenta de cachalotes (GUBANOV, 1951). Os nematoides são animais pseudocelomados (ou seja, possuem uma cavidade entre a mesoderme e a endoderme, na qual se formam os sistemas) e possuem simetria bilateral. Possuem corpo recoberto por cutícula composta essencialmente de colágeno de origem epidérmica, muito resistente e impermeável, que permite a dispersão dos vermes e colonização de diversos ambientes. Nematoides de vida livre estão amplamente espalhados em ambientes terrestres e aquáticos, e são resistentes às condições ambientais mais extremas. Assim como os de vida livre, os nematoides parasitas são muito bem sucedidos. Há estimativas de que quase todos os vertebrados terrestres possuem pelo menos uma espécie de nematoide parasita associada (BUNDY, 1997). Nematoides parasitas de seres humanos infectam mais de um terço da população mundial (HOTEZ et al., 2006), sendo as crianças as mais afetadas.

As classificações mais antigas dos nematoides se baseavam apenas em características morfológicas (LEY, 2006). Blaxter et al. (1998) fizeram a primeira filogenia usando dados moleculares, na qual foram utilizadas as sequências do RNA (SSU rRNA) da subunidade menor do ribossomo de 53 espécies. Atualmente, mais de 8000 nematoides possuem estas sequências disponíveis, sendo mais de 4000 destas de espécies já descritas (BLAXTER; 
KOUTSOVOULOS, 2014). A Filogenia mais aceita hoje em dia classifica os nematoides em três classes: Enoplia, Dorylaimia e Chromadoria (Figura 1.1).

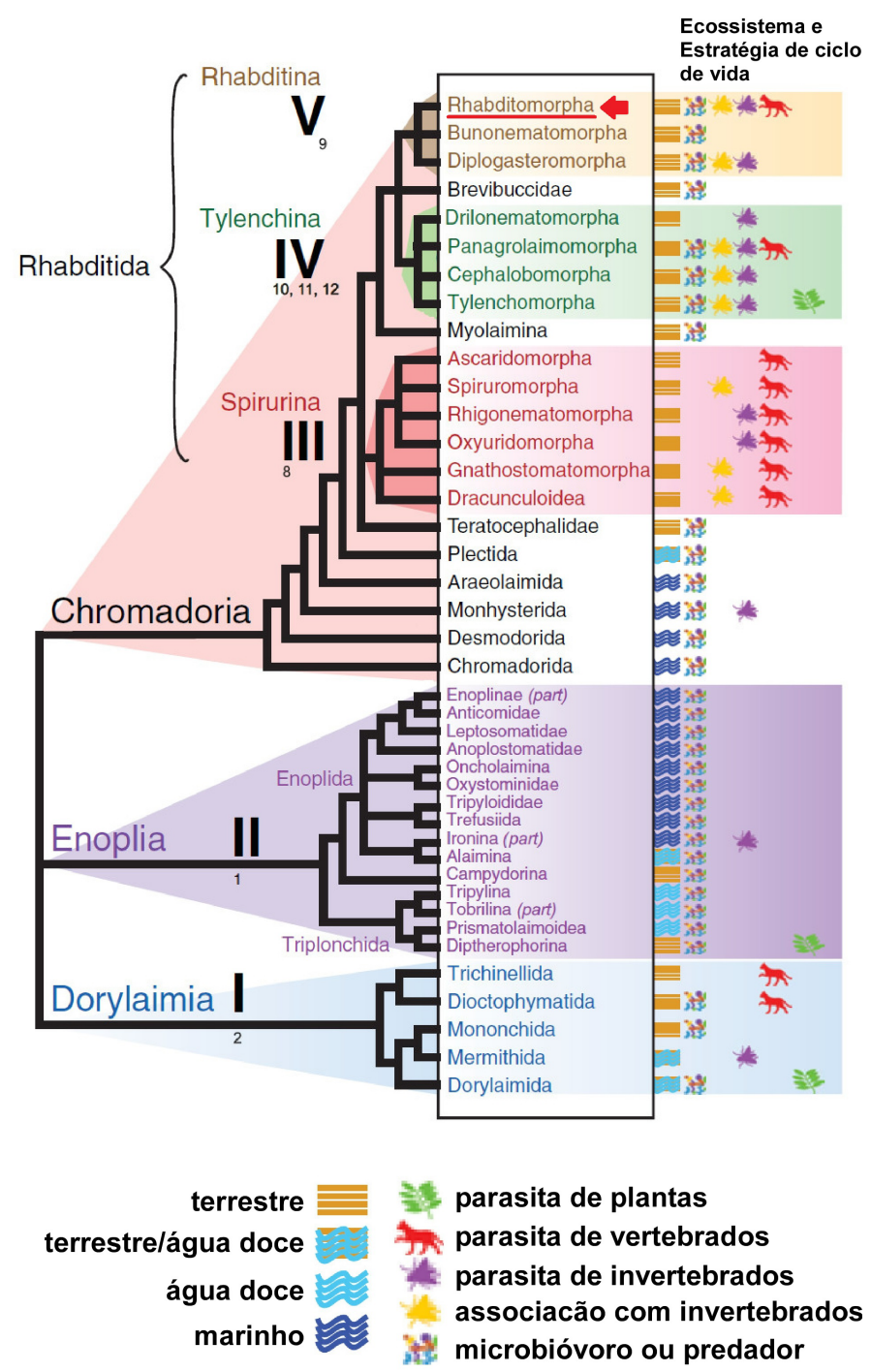

Figura 1.1: Estrutura filogenética do Filo Nematoda, baseada na análise da estrutura menor do RNA ribossômico e em dados morfológicos (LEY, 2006) (BLAXTER; DENVER, 2012). Inclui exemplos de gêneros e nicho ecológico. Figura extraída e modificada de Blaxter e Koutsovoulos (2014).

Os dados do SSU rRNA não resolvem inteiramente esta filogenia, mas sugerem que Enoplia seja a ramificação mais antiga da árvore (BLAXTER; KOUTSOVOULOS, 2014; MEGEN et al., 2009). Os Enoplia são em sua maioria marinhos e de vida livre, sendo comumente encontrados em sedimentos e em alto mar, onde se alimentam de diatomáceas e algas. Mas há também espécies de água doce e algumas parasitas de plantas. Portanto, é aceito atualmente que o Filo Nematoda tenha origem marinha (BLAXTER; KOUTSOVOULOS, 2014). Os Dorylaimia são encontrados em ambiente terrestre e de água doce e é o maior grupo de nematoides parasitas de plantas e animais. Por fim, os Chromadoria são em sua maioria 
marinhos e de ambiente terrestre, incluindo parasitas de plantas e animais e também nematoides de vida livre. Os nematoides do gênero Heterorhabditis, como o utilizado neste trabalho, pertencem à classe Chromadoria, ordem Rhabditida, infraordem Rhabditomorpha (Figura 1.1). Neste grupo também se encontra a espécie Caernohabditis elegans, organismo modelo mencionado anteriormente.

\subsection{Nematoides Entomopatogênicos do gênero Heterorhabditis}

Os nematoides do gênero Heterorhabditis são entomopatogênicos, visto que causam doença e são letais para insetos que possuem alguma fase de vida terrestre (POINAR, 1976). Atualmente, sabe-se que nematoides entomopatogênicos são capazes de matar uma gama de artrópodes, incluindo até carrapatos (VASCONCELOS et al., 2004). A infecção do hospedeiro é feita por uma forma larval de resistência do nematoide, chamada de Juvenil Infectante (Ji), a única fase do desenvolvimento do verme encontrada no solo, ou seja, fora do corpo do inseto hospedeiro. Os Ji's possuem tamanho reduzido e duas cutículas, o que o ajuda a sobreviver em condições extremas. Por isso, essa forma infectante pode ser comparada à larva dauer de Caernohabditis elegans e outros nematoides de vida livre (WOOD, 1988). Por possuírem as duas cutículas e um dente córneo, os Ji's conseguem penetrar ativamente o corpo do hospedeiro ou podem entrar pela boca ou ânus.

Uma das características mais interessantes dos nematoides entomopatogênicos (NEPs) é que eles possuem uma simbiose com bactérias do tipo mutualismo multipartido (HUSSA; GOODRICH-BLAIR, 2013). Os nematoides do gênero Heterorhabditis são simbiontes das bactérias do gênero Photorhabdus, que ficam alojadas na luz intestinal dos Ji's (BOEMARE et al., 1993). Essa especificidade de espécies da simbiose se mantem através de um evento chamado Endotoquia Matricida, que será retomado adiante.

\subsubsection{Ciclo de vida}

Os Ji's são capazes de invadir e matar larvas e adultos de insetos de diferentes ordens. Outra característica que destaca os entomopatogênicos é a sua capacidade de dispersão e busca do hospedeiro e outros artrópodes. Eles são atraídos pelas atividades fisiológicas do hospedeiro, como a respiração (GAUGLER, 1988; MONTEIRO et al., 2012; ZUCKERMAN; JANSSON, 1984). Ao entrar no corpo do hospedeiro, os Ji's regurgitam as bactérias simbiontes na hemolinfa. As bactérias, por sua vez, matam o hospedeiro por septicemia e atuam na bioconversão deste cadáver, processo biológico que torna acessíveis ao nematoide 
moléculas que ele sozinho não poderia utilizar. Esta bioconversão é realizada através de enzimas hidrolíticas que convertem os tecidos do hospedeiro em biomassa bacteriana (ELEFTHERIANOS et al., 2010).

Os Ji's, ao se alimentar da biomassa convertida pelas bactérias, passam para os estádios J3, J4 e então se desenvolvem em adultos hermafroditas de primeira geração (Figura 1.2). Esse adulto é chamado de fêmea protrândrica, pois suas gônadas primeiro produzem espermatozoides que ficam acumulados nas espermatecas e, em seguida produzem os ovócitos que serão auto-fertilizados. As larvas eclodidas passam pelos quatro estádios larvais (J1, J2, J3 e J4) e se desenvolvem na segunda geração de adultos, dessa vez dioica (com presença de machos e fêmeas). Esse ciclo com adultos machos e fêmeas se repete até que a fonte de alimento do cadáver do hospedeiro se esgote, ou a densidade populacional do verme seja muito alta. Nestas condições, os nematoides que deveriam se desenvolver em J3s passam a Ji's, saem do cadáver do hospedeiro (emergem no meio externo, onde podem sobreviver por meses) e o ciclo recomeça quando uma nova vítima é infectada (Figura 1.2). O processo de transformação em Ji é estimulado e controlado por feromônios denominados ascarosídeos (NOGUEZ et al., 2012). Estes ascarosídeos são relacionados em estrutura com os feromônios de dauer em C. elegans. No entanto, os ascarosídeos de C. elegans não induzem Ji em $H$. bacteriophora, propondo que há uma evolução de caráter espécie específico atuando na formação destas moléculas (NOGUEZ et al., 2012). Em laboratório, o ciclo de vida descrito dura aproximadamente 15 dias quando mantido em larvas do lepidóptero Galleria mellonella, sendo que a morte do inseto acontece em aproximadamente 24 horas. Além disso, em laboratório, os Ji's podem sobreviver e continuar infectantes por mais de um ano.

\subsubsection{Simbiose}

A interação entre verme e bactéria é fundamental para o sucesso da infecção do hospedeiro (inseto), pois quando o nematoide o penetra, libera as bactérias na hemolinfa, como descrito anteriormente. Estas, uma vez na hemolinfa, liberam uma série de toxinas e metabólitos secundários que impedem o funcionamento correto da resposta imune inata do inseto (WATERFIELD et al., 2009), causando septicemia e consequente morte do hospedeiro, processo que pode durar entre 24 e 72 horas. E, como também foi descrito anteriormente, as bactérias simbiontes tornam disponíveis alimentos do cadáver do inseto que o nematoide sozinho não conseguiria digerir. Por outro lado, o nematoide funciona como meio de transporte da bactéria de um hospedeiro à outro.

O evento mais interessante envolvendo essa interação é chamado Endotoquia Matricida, 


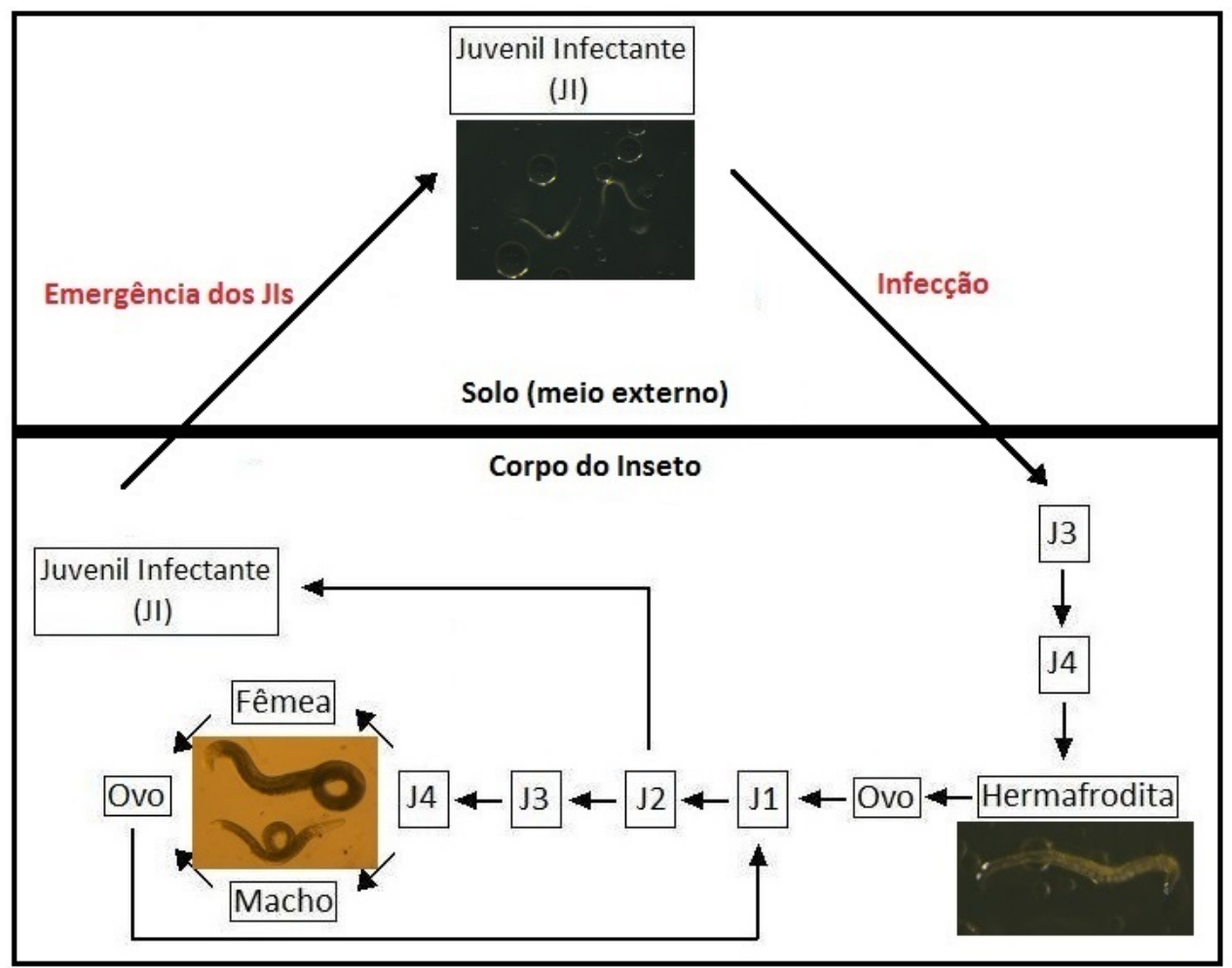

Figura 1.2: Ciclo de vida de Heterorhabditis spp. As fotos ilustrativas são da espécie H. baujardi, linhagem LPP7, modelo utilizado neste trabalho.

no qual os vermes fêmeas não botam seus ovos. Os ovos eclodem ainda dentro do corpo da mãe, que termina por morrer. Isso garante que a simbiose se torne espécie específica quando passada de uma geração a outra do nematoide. Esse fenômeno foi registrado pela primeira vez por Maupas (1899), mas foi Lordello (1951), quem caracterizou pela primeira vez em Rabditídeos. Mais tarde essa caracterização foi confirmada por outros autores. Pouco se sabia nessa época sobre o que de fato acontecia, mas já era observado que as estruturas corporais da fêmea não eram alimento para as larvas recém emergidas, e que estas eram microbióvoras. A manutenção da especificidade desta simbiose se deve também a um outro evento que ocorre durante este processo: as bactérias simbiontes, depois que o verme adulto se alimenta delas, colonizam as duas últimas células do intestino posterior do nematoide e formam um biofilme em sua superfície (SOMVANSHI et al., 2010) (Figura 1.3). Depois disso, invadem as células da glândula retal e se desenvolvem dentro de seus vacúolos. Essas células são lisadas e as bactérias então invadem o pseudoceloma do verme mãe, local onde as larvas estão eclodindo (SOMVANSHI et al., 2010). Isso garante que nos primeiros momentos de vida, as larvas se alimentem apenas das bactérias simbiontes presentes dentro do pseudoceloma materno, bactérias estas que colonizarão a luz intestinal das larvas, impedindo o crescimento de outras bactérias e garantindo a manutenção do mutualismo multipartido de uma geração para a outra (HUSSA; GOODRICH-BLAIR, 2013). 


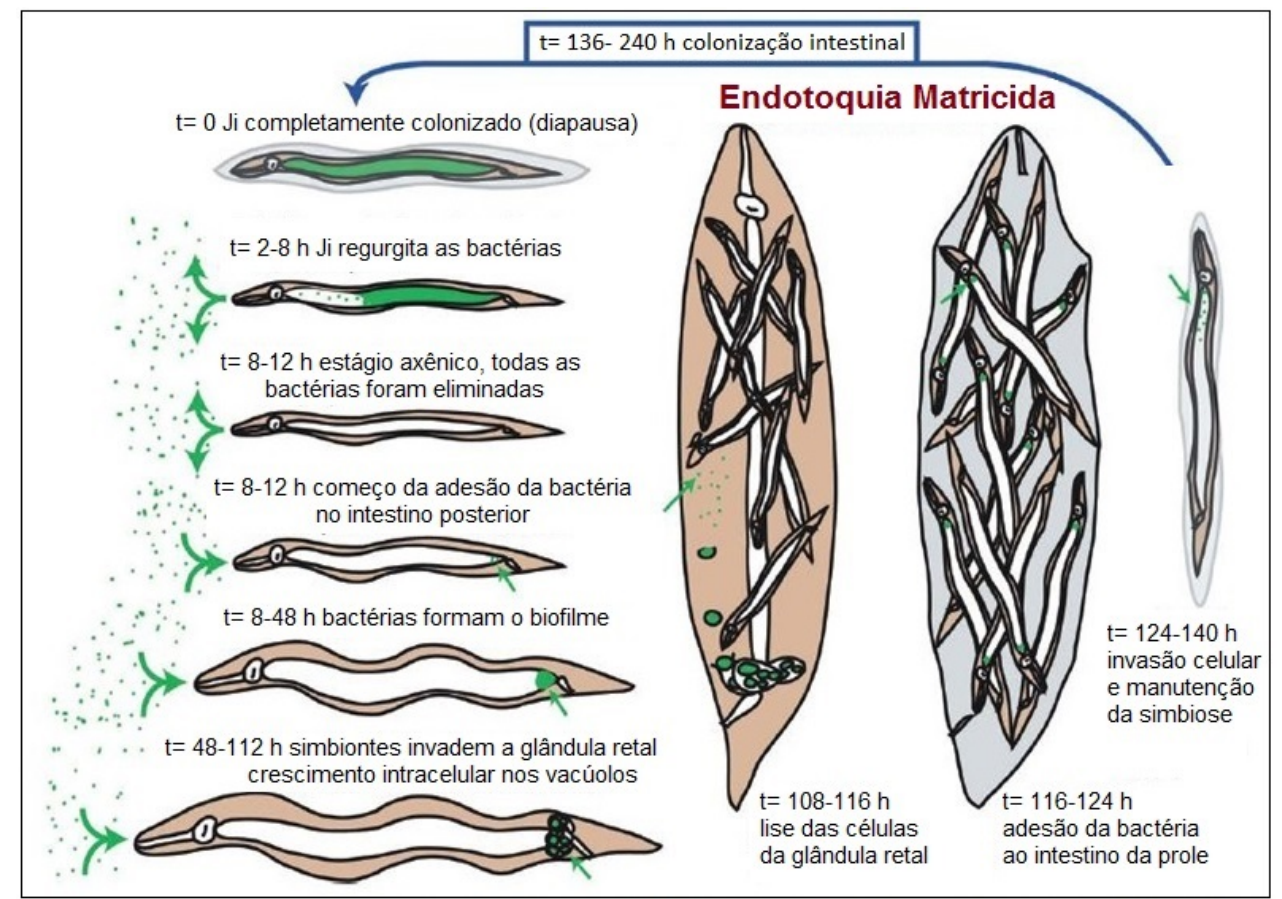

Figura 1.3: Esquema da Endotoquia Matricida. Atuação das bactérias Photorhabdus spp. Na colonização do intestino e pseudoceloma dos vermes Heterorhabditis spp. Figura extraída e modificada de Somvanshi et al. (2010)).

\subsubsection{Controle Biológico de Insetos Praga}

Heterorhabditis spp. têm despertado há muitos anos o interesse em seu uso como agentes para controle biológico de pragas em plantações, pois infectam e matam insetos de forma eficiente, sem o uso de agrotóxicos. Há relatos do uso de NEPs como controle biológico desde a década de 30, porém, foi na década de 70 que os estudos relacionados a esse uso começaram a aumentar. A maior vantagem deste tipo de aplicação está na diminuição do uso de pesticidas nocivos à saude. Porém, o uso de NEPs como controle ainda custa muito caro, o que limita o uso desta técnica a culturas de alto valor comercial (GAUGLER, 2002). Além disso, algumas aplicações destes nematoides ainda estão em fase de testes. Hoje em dia já existem algumas empresas que atuam na produção em massa de NEPs e existem protocolos prontos para aplicação. A Tabela 1.1 mostra alguns exemplos de aplicação de nematoides do gênero Heterorhabditis em diferentes culturas (ALMENARA et al., 2012).

No Brasil, estudos mostram que espécies do gênero Heterorhabditis foram eficientes no combate ao bicho da goiaba, Conotrachelus psidii (Coleoptera: Curculionidae) (DOLINSKI et al., 2006). Uma das linhagens testadas na cultura da goiaba foi a linhagem LPP7 de H. baujardi, utilizada no presente trabalho. Dolinski et al. (2006) mostraram que H. baujardi é altamente virulenta para larvas de quarto estádio do inseto, sendo um possível alvo para aplicação em 
culturas comerciais. Outro estudo mostra que juvenis infectantes de Heterorhabditis indica podem ser utilizados contra a lagarta-do-cartucho (Spodoptera frugiperda), uma praga de milho (GARCIA et al., 2008). Os nematoides do gênero Heterorhabditis se mostraram praticamente tão eficientes no controle da lagarta-do-cartucho quanto nematoides do gênero Steinernema ${ }^{1}$, no entanto é necessário um número maior de Jis do primeiro.

Tabela 1.1: Aplicação de NEPs no controle biológico de insetos praga. Extraída e adaptada de Almenara et al. (2012)

\begin{tabular}{|c|c|c|c|}
\hline Nematoide & Artrópode-praga & $\begin{array}{l}\text { Cultura } \\
\text { agrícola/animal } \\
\text { afetado }\end{array}$ & Referência \\
\hline $\begin{array}{l}\text { S. carpocapsae; } \\
\text { H. downesi }\end{array}$ & $\begin{array}{l}\text { Hylobius abietis } \\
\text { (Gorgulho do } \\
\text { Pinheiro) }\end{array}$ & Pinheiros & Girling et al., 2010 \\
\hline $\begin{array}{l}\text { H. marelatus; } \\
\text { S. kraussei; } \\
\text { S. carpocapsae }\end{array}$ & $\begin{array}{l}\text { Cydia latiferreana } \\
\text { (Lagarta) }\end{array}$ & Avelãs, Amêndoas & $\begin{array}{l}\text { Bruck \& Walton, } \\
2007 .\end{array}$ \\
\hline $\begin{array}{l}\text { H. bacteriophora; } \\
\text { H. spp. }\end{array}$ & $\begin{array}{l}\text { Dysmicoccus texensis } \\
\text { (Colchonilha da } \\
\text { Raiz do Cafeeiro) }\end{array}$ & Café & Alves et al.,2009. \\
\hline $\begin{array}{l}\text { H. indica; H. } s p . ; \\
\text { S. carpocapsae }\end{array}$ & $\begin{array}{l}\text { Bradysia mabiusi } \\
\text { (Mosca-dos-fungos) }\end{array}$ & $\begin{array}{ll}\text { Viveiros de } & \\
\text { sementes, } & \\
\text { Cogumelos, Soja, } \\
\text { Eucalipto, entre } \\
\text { outros }\end{array}$ & Leite et al., 2007 \\
\hline $\begin{array}{l}\text { S. carpocapsae; } \\
\text { S. riobrave; } \\
\text { S. feltiae; } \\
\text { H. amazonensis }\end{array}$ & $\begin{array}{l}\text { Mahanarva sp. } \\
\text { (Cigarrinha) }\end{array}$ & $\begin{array}{l}\text { Cana-de-açúcar, } \\
\text { Pastagens }\end{array}$ & Leite e cols.; 2003 \\
\hline $\begin{array}{l}\text { S. carpocapsae; } \\
\text { H. indica }\end{array}$ & $\begin{array}{l}\text { Diaprepes abbreviatus } \\
\text { (Besouro perfurador } \\
\text { de raiz) }\end{array}$ & Diferentes cultivares & $\begin{array}{l}\text { Shapiro-Ilan et al.; } \\
2010\end{array}$ \\
\hline $\begin{array}{l}\text { S. carpocapsae; } \\
\text { H. indica }\end{array}$ & $\begin{array}{l}\text { Aethina tumida } \\
\text { (Pequeno } \\
\text { escaravelho de } \\
\text { colmeias) }\end{array}$ & Colmeias & $\begin{array}{l}\text { Shapiro-Ilan et al.; } \\
2010\end{array}$ \\
\hline $\begin{array}{l}\text { S. carpocapsae; } \\
\text { S. riobrave; } \\
\text { H. bacteriophora }\end{array}$ & $\begin{array}{l}\text { Cydia pomonella } \\
\text { (Traça da maçã) }\end{array}$ & Macieiras & $\begin{array}{l}\text { Lacey \& Unruy; } \\
1998\end{array}$ \\
\hline
\end{tabular}

Os estudos sobre esse gênero têm crescido muito nos últimos anos, e não apenas no âmbito

\footnotetext{
${ }^{1}$ Steinernema (ver (STOCK et al., 2001)) é um outro gênero de nematoides entomopatogênicos, com muitas características em comum com Heterorhabditis, possuindo algumas diferenças de ciclo de vida e infectividade. Os nematoides deste gênero também possuem simbiose espécie específica com bactérias, que neste caso são do gênero Xenorhabdus
} 
do controle de pragas, mas também nos aspectos da ecologia, evolução, bioquímica e biologia molecular.

O nematoide entomopatogênico objeto deste estudo é o Heterorhabditis baujardi linhagem LPP7. Trata-se de um isolado obtido em Monte Negro (RO) por Dolinski et al. (2008). Sua bactéria simbionte é Photorhabdus luminescens linhagem MN7, isolada em nosso laboratório. Os Ji's de Heterorhabditis baujardi LPP7 atingem a idade adulta em aproximadamente 3 dias, quando cultivados a $28{ }^{\circ} \mathrm{C}$ em larvas de Galleria mellonella. Além disso, podem ser cultivados in vitro, em placas de meio contendo extrato-de-carne/agar e inóculo do simbionte parceiro P. luminescens MN7.

\subsection{Vitelogenina}

Todo animal precisa ser alimentado durante o desenvolvimento embrionário. Nos vertebrados placentários, a alimentação é direta de mãe para filho, além de ser constante. Porém, para os animais ovíparos, é necessário que se faça uma reserva alimentar dentro do ovo que garanta seu desenvolvimento embrionário e pós- embrionário. O vitelo tem a função de suprir as necessidades nutritivas destes embriões. Ele é composto em sua maioria por lipídeos, proteínas, carboidratos e íons, além de possuir fatores de controle de desenvolvimento maternos. Portanto, pode-se considerar que as proteínas do vitelo estejam entre as mais importantes proteínas para a reprodução, desenvolvimento e manutenção da maioria dos animais. A formação do vitelo é chamada de vitelogênese, e é controlada por diversos fatores em diferentes grupos de animais.

$\mathrm{Na}$ maioria dos ovíparos, as principais proteínas do vitelo (vitelinas) têm origem extraovariana a partir de um precursor chamado vitelogenina (LIM et al., 2001). A vitelogenina é uma proteína transportadora de lipídeos para o ovócito em formação. Esta é uma via que garante, portanto, que se formem estas reservas alimentares tão importantes para o desenvolvimento animal. O nome vitelogenina foi dado por Telfer (1954), quando observou a presença de uma proteína na hemolinfa de fêmeas de Lepidoptera que era imunologicamente idêntica as proteínas que se acumulavam nos ovócitos em formação. Ele observou que esta proteína só estava presente em fêmeas. Atualmente, chama-se de vitelina (VT) a proteína internalizada nos ovócitos, para diferenciar da vitelogenina (VTG), que é a proteína precursora circulante $^{2}$. A partir de dados filogenéticos e de estrutura, as vitelogeninas foram incluídas

\footnotetext{
${ }^{2}$ No caso de extrações proteicas do nematoide Heterorhabditis baujardi LPP7, é praticamente impossível distinguir a vitelogenina da vitelina armazenada nos ovócitos, já que a tomada dessas proteínas para dentro dos ovócitos é imediato, impedindo a separação da vitelogenina em si. Portanto, as proteínas do vitelo de $H$. baujardi caracterizadas em nosso laboratório receberam as denominações VT, pois trata-se quase que exclusivamente de
} 
numa grande família de lipoproteínas chamada LLTPs ("large lipid transfer proteins") (MANN et al., 1999).

A produção da vitelogenina compreende quatro etapas: biossíntese, processamento proteolítico, transporte e tomada pelos ovócitos. Em nematoides, a biossíntese acontece no intestino e o processamento no pseudoceloma. Já em insetos, a biossíntese se dá no corpo gorduroso e o processamento na hemolinfa. Sabe-se que em insetos, a vitelogênese é controlada pelo hormônio juvenil e ecdisona (DHADIALLA; RAIKHEL, 1990), enquanto nos vertebrados é controlada por estrógeno (WAHLI, 1988; WALLACE, 1985).Em nematoides o controle não foi completamente elucidado, mas é aceito que ele seja dependente de hormônios derivados de colesterol (MATYASH et al., 2004).

Em C. elegans, seis genes (vit-1, vit-2, vit-3, vit-4, vit-5 e vit-6) codificam os quatro polipeptídeos da vitelogenina (YP170A, YP170B, YP115 e YP88) (BLUMENTHAL et al., 1984). O gene vit-6 se encontra no cromossomo IV, enquanto todos os outros estão no cromossomo X (HEINE; BLUMENTHAL, 1986). Os seis genes de VTG são expressos em quantidades diferentes, sendo que o nível de expressão foi determinado pelo número de ESTs depositados no banco de dados desta espécie (Figura 1.4) (WORMBASE, Acesso em: 2014, ago.).

Os genes vit-1 e vit-2 codificam o polipeptídeo YP170B, os genes vit-3, vit-4 e vit-5 codificam o polipeptídeo YP170A. Por último, o gene vit-6 codifica o precursor dos polipeptídeos YP115 e YP88 (Figura 1.4). Este precursor sofre clivagem no pseudoceloma para formar estes dois peptídeos, assim que é secretado do intestino e logo antes de ser tomado pelo ovócito. Estudos sugerem que a clivagem do precursor ocorra através de uma enzima do tipo pró-hormônio convertase, pois está presente, na região de clivagem, o par de aminoácidos básicos Lisina-Arginina (ANDREONI-NICO, 2008; WINTER et al., 1996).

Os quatro peptídeos de VTG em C. elegans formam dois complexos: um dímero de YP170B e um heterotrímero formado por YP170A, YP115 e YP88 (SHARROCK, 1983) (Figura 1.5). Estes complexos são tomados via receptores (SCHNEIDER, 1996) e armazenados em grânulos de vitelo.

Em Oscheius tipulae ${ }^{3}$, os genes de vitelogenina codificam três polipeptídeos, chamados de VT1 (175 kDa), VT2 (107 kDa) e VT3 (82 kDa) para a linhagem CEW1 (ALMENARA et al., 2013) (Figura 1.6). Até o momento foram estudados dois genes de VTG nesta espécie:

vitelinas.

${ }^{3}$ O. tipulae é um nematoide Rabditídeo de vida livre (FÉLIX, 2006), e uma linhagem desta espécie, a CEW1, foi extensamente estudada em nosso laboratório. Estes estudos envolveram principalmente a caracterização das vitelinas e da vitelogênese deste nematoide. 


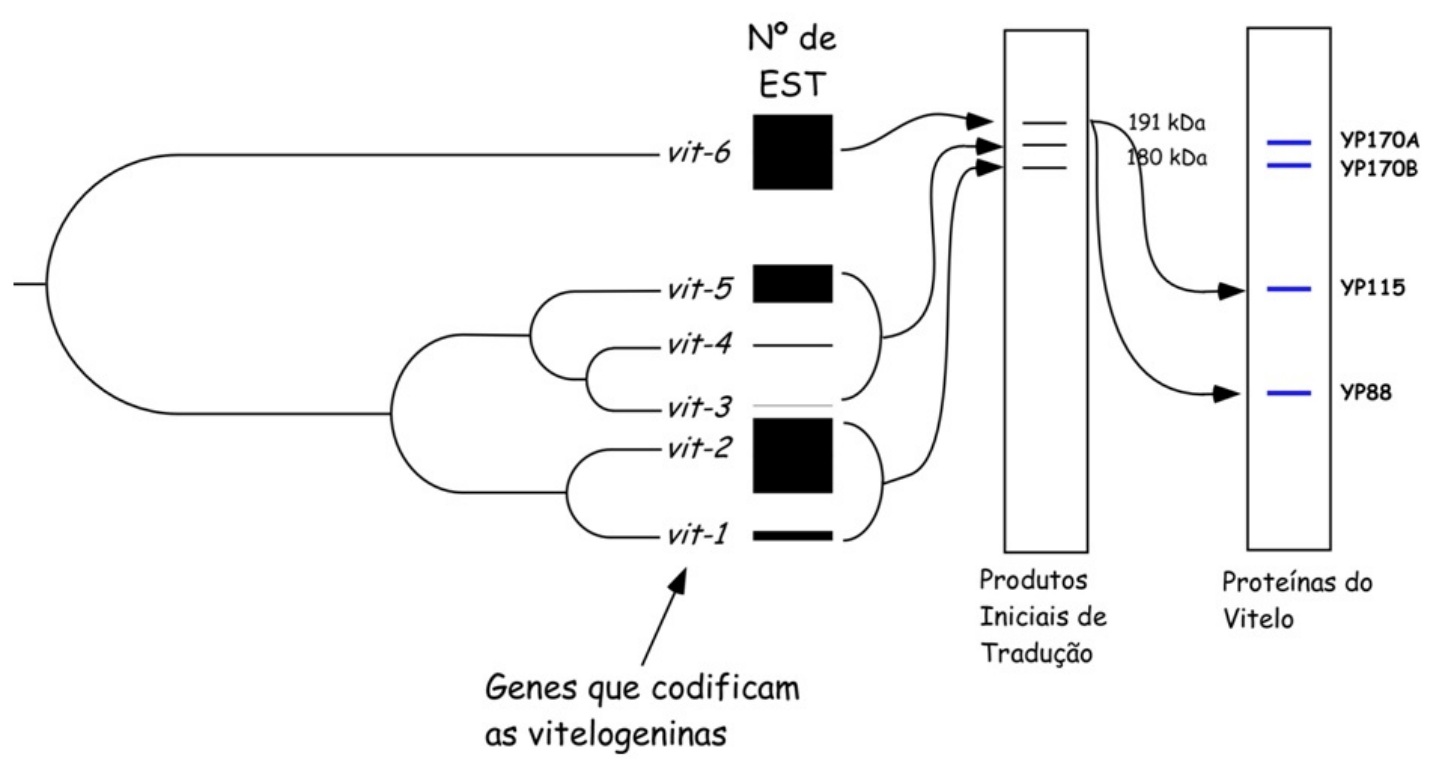

Figura 1.4: Genes e polipeptídeos de vitelogenina de C. elegans. As setas indicam quais produtos inciais da tradução cada gene transcreve, bem como as proteínas de vitelo que cada precursor origina. Os retângulos pretos indicam, pela espessura, a proporção de ESTs depositados no projeto genoma da espécie. Figura extraída e modificada de Spieth et al. (1985)

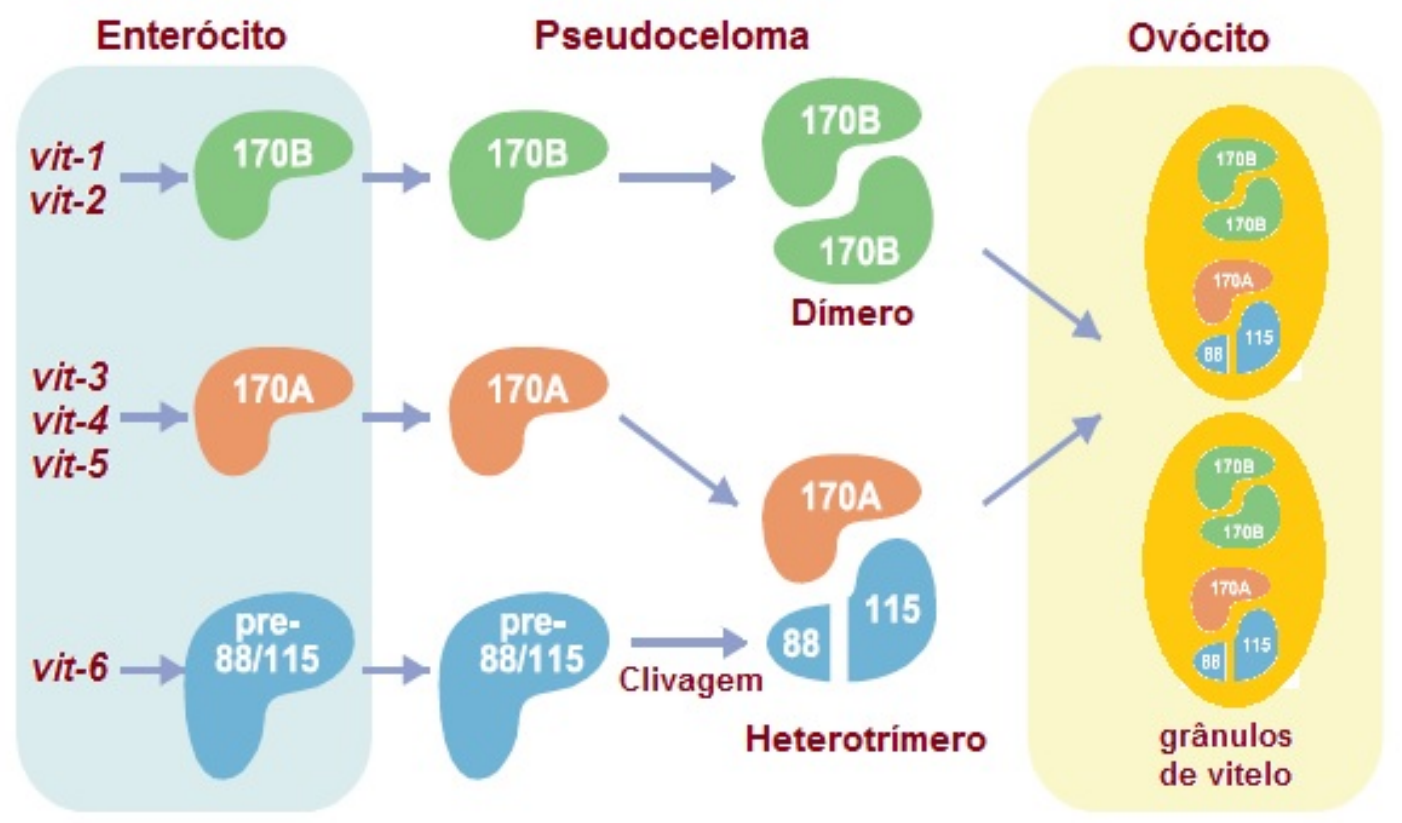

Figura 1.5: Esquema da vitelogênese em C. elegans. Os precursores da vitelogenina são produzidos dentro dos enterócitos e secretados no pseudoceloma, onde podem sofrer processamento, como é o caso do precursor preYP88/YP115. A vitelogenina na forma nativa é então tomada nos ovócitos via receptores, e é armazenada na forma de grânulos de vitelo. Neste momento, as proteínas levam o nome de vitelinas. Figura extraída e modificada de Sharrock et al. (1990)

Oti-vit-6 e Oti-vit-1. Os polipeptídeos VT2 e VT3 são secretados do intestino na forma de um precurssor único e, da mesma forma como acontece em C. elegans, este precursor é clivado no pseudoceloma pela provável ação de uma convertase. O gene que codifica este precurssor é o 
Oti-vit-6. O polipeptídeo VT2 corresponde à região carboxi-terminal do precursor, enquanto o VT3 corresponde à região amino-terminal (MOURA, 2004).

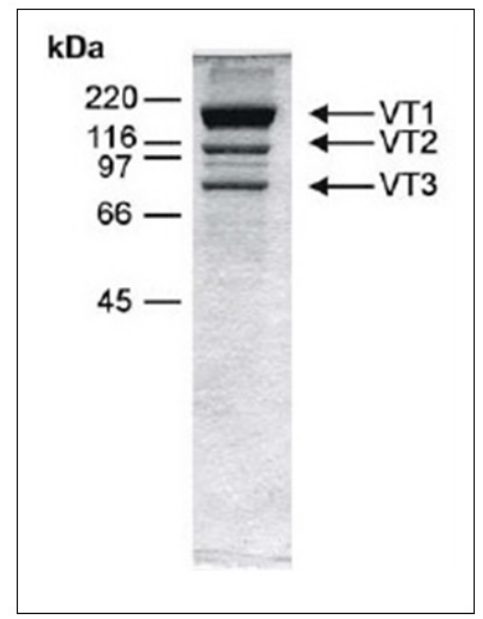

Figura 1.6: SDS-PAGE mostrando os polipeptídeos de vitelo de $O$. tipulae CEW1. As bandas correspondem aos três polipeptídeos VT1 (175 kDa), VT2 (107 kDa) e VT3 (82 kDa), purificados por cromatografia de afinidade em coluna de Con A-Sepharose (PENHA-SCARABOTTO, 1999). Figura extraída e modificada de Almenara et al. (2013).

Os genes da vitelogenina são muito conservados entre os metazoários e fazem parte de uma família multigênica (pode ter de 2 a 6 genes) (BYRNE et al., 1989; CHEN et al., 1997; WANG et al., 2000). A atuação destes genes é de forma dose-dependente, ou seja, quanto mais cópias um animal possui dos genes, mais vitelogenina ele produz. Isso pode ser observado em alguns grupos de peixes, que possuem muitas cópias dos genes vit, o que resulta em uma alta produção de ovos em pouco tempo. Já aves e répteis possuem poucas cópias destes genes, produzindo então poucos ovos (BUISINE et al., 2002).

A expressão gênica da vitelogenina é controlada diretamente por um gene chamado male-abnormal, que se encontra à jusante na cascata de genes envolvidos na determinação de sexo em C. elegans $\left(\mathrm{Cel}-\mathrm{mab}-3^{4}\right)$. Este gene atua reprimindo a expressão dos genes de VTG em machos. Yi e Zarkower (1999) mostraram que a proteína MAB-3 impede a transcrição do gene Cel-vit-2, ligando-se à sua região promotora. Esses dados foram mostrados utilizando linhagens transgênicas de C. elegans contendo o gene Cel-vit-2 :: GFP. Machos adultos mutantes com deleção deste gene são capazes de produzir vitelogenina, que fica acumulada no pseudoceloma (SHEN; HODGKIN, 1988), enquanto adultos hermafroditas mutantes para este mesmo gene possuem fenótipo selvagem.

A expressão da vitelogenina tem outro controle, além do sexo-específico. Dois motivos altamente conservados (VPE1 e VPE2 - Vitellogenin Promoter Element) fazem parte da região

\footnotetext{
${ }^{4}$ A sigla em letras minúsculas refere-se ao nome do gene, e a sigla em letras maiúsculas refere-se ao nome da proteína.
} 
5' UTR dos genes de vitelogenina de C. elegans e atuam no controle tecido, estágio-específico e quantitativo da produção de vitelogenina (SPIETH et al., 1988; ZUCKER-APRISON; BLUMENTHAL, 1989). Vermes com mutações na região promotora com estes motivos tiveram as taxas de transcrição de YP115 alterada nos enterócitos (SPIETH et al., 1988).

As sequências consenso destes dois motivos, VPE1 e VPE2, são, respectivamente: TGTCAAT e GTGATAA. Estas são semelhantes, respectivamente, ao "CCAT box" de mamíferos e ao sítio de ligação do fator de transcrição GATA, ativado de genes de eritrócitos em mamíferos (ORKIN, 1992). Os fatores de transcrição do tipo GATA em C. elegans encontrados até agora são quatro, e seus genes são transcritos tanto em tecidos embrionários quanto em células intestinais, atuando na diferenciação celular destas (MCGHEE et al., 2009). 


\section{OBJETIVOS}

\subsection{Objetivo geral}

O objetivo deste trabalho foi caracterizar os polipeptídeos do vitelo de Heterorhabditis baujardi LPP7, proveniente de Monte Negro (RO), bem como os genes que codificam estas proteínas.

\subsection{Objetivos específicos}

Os objetivos específicos deste trabalho foram:

- Manter a cultura de H. baujardi LPP7 in vitro;

- Purificar as vitelogeninas de H. baujardi LPP7 e caracterizar bioquimicamente os polipeptídeos;

- Isolar até a homogeneidade por critérios eletroforéticos as proteínas do vitelo de H. baujardi LPP7;

- Obter antissoros monoespecíficos para cada um dos polipeptídeos do vitelo de H. baujardi LPP7 e realizar ensaios de imunofluorescência;

- Produzir cDNAs para os mRNAs de Hba-vit-6

- Clonar os fragmentos do(s) cDNA(s) de Hba-vit-6 em E. coli e caracterizá-los. 


\section{MATERIAL E MÉTODOS}

\subsection{Bactérias}

\subsubsection{Linhagens de Escherichia coli utilizadas}

DH5- $\alpha$ (supE44 Dlac U169 hsdR17 recA1 endA1 gyrA96 thi-1 relA1) (YOUNG; DAVIS, 1983); NA22, cedida pelo Dr. Thomas Blumenthal - University of Colorado, Boulder; originária).

\subsubsection{Preparação de bactérias DH5- $\alpha$ quimio-competentes}

Uma colônia individualizada de bactérias da linhagem DH5- $\alpha$ foi inoculada em $3 \mathrm{ml}$ de meio $L B^{5}$ e crescida durante aproximadamente 16 horas a $37^{\circ} \mathrm{C}$ sob agitação constante. $100 \mu \mathrm{l}$ deste pré-inóculo foram adicionados a $100 \mathrm{~mL}$ do mesmo meio. Esta segunda cultura foi incubada também sob agitação e temperatura de $37^{\circ} \mathrm{C}$ por aproximadamente quatro horas até a cultura atingir A600nm de 0,500, sendo então centrifugada a $4000 \mathrm{~g}$ por 10 minutos a $4{ }^{\circ} \mathrm{C}$. As bactérias foram ressuspendidas em $\mathrm{CaCl} 250 \mathrm{mM}$ e incubadas a $4{ }^{\circ} \mathrm{C}$ por 20 minutos. As suspensões foram novamente centrifugadas sob as mesmas condições e os precipitados ressuspendidos em $\mathrm{CaCl} 250 \mathrm{mM}$, glicerol 15\%. As bactérias competentes foram congeladas em nitrogênio líquido e armazenadas a $-70^{\circ} \mathrm{C}$ até o uso.

\subsubsection{Transformação de bactérias DH5- $\alpha$ quimio-competentes}

Cerca de 150-200 ng de DNA plasmidial foram adicionados a $80 \mu l$ de bactérias competentes e mantidos a $4{ }^{\circ} \mathrm{C}$ por 30 minutos. O choque térmico foi dado a $42{ }^{\circ} \mathrm{C}$ por um minuto seguidos de dois minutos a $4{ }^{\circ} \mathrm{C}$. Foram adicionados $800 \mu l$ de meio $L B$ e as misturas de transformação foram mantidas a $37^{\circ} \mathrm{C}$ por uma hora sem agitação. Para seleção dos clones transformados, $30 \mu l$ da cultura foram plaqueados em meio LB agar adicionado do antibiótico apropriado, X-Gal $122 \mathrm{mM}$ e IPTG $^{6} 100 \mathrm{mM}$ para identificação dos clones recombinantes. As placas foram incubadas por 16 horas a $37^{\circ} \mathrm{C}$.

\footnotetext{
${ }^{5}$ As soluções utilizadas estão em itálico nesta seção e encontram-se descritas na tabela do item 3.5

${ }^{6}$ Para definição das abreviaturas ver em uma das páginas não numeradas que precedem o corpo desta tese, como preconizado pelas normas de formatação de dissertações da ABNT.
} 


\subsubsection{Linhagens de Photorhabdus luminescens utilizadas}

MN7 (simbionte do nematoide Heterorhabditis baujardi LPP7, isolada e mantida em laboratório); MN12 (simbionte do nematoide Heterorhabditis indica LPP12, isolada e mantida em laboratório). Ambas as linhagens foram congeladas em nitrogênio líquido a $-70{ }^{\circ} \mathrm{C}$ e são mantidas em meio LB piruvato agar.

\subsection{Nematoide}

\subsubsection{Linhagem de Nematoide Entomopatogênico utilizada}

Heterorhabditis baujardi LPP7. Essa linhagem foi isolada pela Dra. Cláudia Dolinski (Universidade do Norte Fluminense) na cidade de Monte Negro, RO, Brasil.

\subsubsection{Cultivo de Heterorhabditis baujardi LPP7 em Galleria mellonella}

Foram realizadas infecções em larvas de Galleria mellonella de $3^{\circ}$ ou $4^{\circ}$ estádio (Lepidoptera: Pyralidae) com Ji's de H.baujardi, segundo procedimento descrito por Woodring e Kaya (1988). Juvenis infectantes (Ji’s) foram coletados das armadilhas de White (WHITE, 1927). Posteriormente, os Ji's coletados foram armazenados em suspensão aquosa a $16{ }^{\circ} \mathrm{C}$ (VALLE et al., 2008a; VALLE et al., 2008b). A nova infecção foi realizada em uma placa de Petri $(9 \mathrm{~cm})$ forrada com papel de filtro, onde foram colocadas 10 larvas de G. mellonella. Para cada larva foram utilizados em média de 30 a 40 Ji's de H. baujardi LPP7, que foram distribuídos pela placa, em $1 \mathrm{ml}$ de água destilada. Após aproximadamente 7 dias, os cadáveres de G. mellonella infectados foram transferidos para a armadilha de White, na qual a nova geração de Ji's emergiria depois de mais 7 dias.

\subsubsection{Cultivo in vitro de Heterorhabditis baujardi $L P P 7$}

H. baujardi foi mantido também in vitro de acordo com o método descrito por Kaya e Stock (1997). Os juvenis infectantes da linhagem LPP7 foram incubados com hipoclorito de sódio $10 \%$ por 8 minutos e então lavados com Tampão $S$ e colocados em placas com meio FLA pré-inoculadas com P. luminescens MN7. Após 4 dias, aproximadamente, foram encontradas fêmeas com ovos, que foram recolhidas em tampão salino [ $\mathrm{NaCl} 0,85 \%(\mathrm{p} / \mathrm{v})]$ e congeladas em nitrogênio líquido. Além disso, a fim de testar a infectividade do nematoide contra o inseto, foram feitos repiques de gerações mantidas apenas in vitro. Para isso, após 15 dias os 
nematoides eram transferidos para novas placas de meio FLA pré inoculadas com MN7. Ainda para testes de infectividade, foram utilizadas placas de meio FLA pré inoculadas com outras duas linhagens de bactéria descritas acima: MN12 e NA22.

\subsubsection{Contagem e cálculo da Infectividade de H. baujardi LPP7 mantido in vitro}

O ensaio envolveu a observação qualitativa de infectividade, considerando que uma infecção satisfatória seria aquela que permitisse o nematoide completar seu ciclo de vida in vivo, ou seja, quando houvesse emergência de nematoides com 15 a 17 dias pós infecção, mesmo que emergissem poucos nematoides. Além disso, foi realizado o cálculo quantitativo em porcentagem, de acordo com o número de infecções satisfatórias num total de 10 infecções. Os ensaios foram feitos em duplicata. Para a infecção, os nematoides foram extraídos da placa através de lavagem com tampão $S$ ou tampão $M 9$, e lavados com o mesmo tampão duas vezes, por 5 minutos cada. Depois disso foram distribuidos em placas de petri de $2 \mathrm{~cm}$ com papel filtro e uma única larva de G. mellonella.

\subsection{Manipulação e Análise de Ácidos Nucleicos}

\subsubsection{Extração de RNA total de Heterorhabditis baujardi LPP7 pelo método do Tiocianato de Guanidina}

Esta extração foi realizada segundo o método de Chirgwin et al. (1979), com algumas modificações. Este método proporciona um grau maior de pureza do RNA extraído. Os vermes congelados foram moídos em gral e o pó foi ressuspendido em Tampão de Homogeneização para volume final $27 \mathrm{ml}$. O homogeneizado resultante foi passado por seringa para quebrar o DNA e centrifugada a $8000 \mathrm{rpm}$ por 15 minutos. O sobrenadante foi então transferido para um tubo de policarbonato onde já havia um "colchão" de $\mathrm{CsCl}$ 5,7 M [em EDTA $50 \mathrm{mM}$ ]. A amostra foi então centrifugada a $60.000 \mathrm{rpm}$ por 4,5 horas a $20{ }^{\circ} \mathrm{C}$ (centrífuga Beckman L8M; rotor Type $70.1 \mathrm{Ti}$ ) (Beckman Coulter, Inc., Brea, California, Estados Unidos da América). O pellet de RNA foi ressuspendido em TES, transferido para um tubo Corex de $15 \mathrm{~mL}$ e a mistura foi agitada em Vórtex até dissolução completa do precipitado. Depois disso, foram adicionados 2 volumes de $\mathrm{CHCl}_{3}$-butanol (4:1) e a mistura foi agitada em Vórtex por 5 minutos. A mistura foi centrifugada $6000 \mathrm{rpm}$, a $25^{\circ} \mathrm{C}$ por 20 minutos para separar as fases e foi adicionado à fase orgânica $2 \mathrm{ml}$ de TES. A fase orgânica foi reextraída mais duas vezes, até não sobrar mais nada na interface. Foi então adicionado à fase aquosa, 0,1 volume de Acetato de Sódio 3,0 M (pH 5,2) e 2,2 volumes de EtOH gelado. A precipitação ocorreu overnight a $-20{ }^{\circ} \mathrm{C}$. No outro dia, 
a amostra foi centrifugada a $8500 \mathrm{rpm}$ por 10 minutos e o pellet foi seco sob vácuo em 'speed vac' SC100 (Savant) e ressuspendido em $3 \mathrm{ml}$ de água e precipitado com etanol gelado, após adição de Acetato de sódio para 0,1 M final. O RNA total precipitado, foi armazenado em EtOH $70 \%$ a $-20{ }^{\circ} \mathrm{C}$.

\subsubsection{Purificação de RNA mensageiro de Heterorhabditis baujardi LPP7}

O kit utilizado neste experimento foi o "Dynabeads $\AA$ mRNA DIRECT ${ }^{T M}$ Micro Kit" (Invitrogen - Life Technologies, Carlsbad, California, Estados Unidos da América). Neste caso, o Kit foi adaptado às necessidades do projeto, e o mRNA foi purificado a partir de RNA total, e não diretamente de tecido, como sugerido no manual do Kit. Dessa forma, não foi necessário usar o tampão de lise de tecido, a não ser na lavagem das Dynabeads $($. O protocolo adaptado inclui os seguintes passos: o pellet de RNA total foi ressuspendido em água estéril livre de pirogênio e este material foi então transferido para um microtubo contendo Dynabeads $囚$-oligo dT pré lavadas com tampão de lise (Tris-HCl 100 mM, pH 7.5; LiCl 500 mM; EDTA, pH 8.0 $10 \mathrm{mM}$; LiDS (dodecil sulfato de lítio) 1\% e dithiothreitol $5 \mathrm{mM}$ ). A mistura foi agitada por 5 minutos à temperatura ambiente. O tubo foi então colocado por 30 segundos em uma estante magnética para isolamento do complexo de mRNA ligado às Dynabeads $(\mathbb{R}$. O sobrenadante foi removido e o complexo mRNA + Dynabeads $囚$-oligodT foi lavado duas vezes com tampão de lavagem B (Tris-HCl, pH 7,5 10 mM; LiCl 0,15 M; EDTA $1 \mathrm{mM}$ ). O mRNA foi eluído das Dynabeads $囚$-oligodT em Tris- $\mathrm{HCl} 10 \mathrm{mM}$ e o processo foi repetido uma vez para que obtivéssemos um mRNA mais puro.

\subsubsection{RNAseq de Heterorhabditis baujardi LPP7}

Sequenciamento de mRNA: foi feito através do sequenciador SOLID. O sequenciamento foi realizado pelo grupo CEFAP (ICB-USP). A metodologia baseia-se na ligação sequencial com oligonucleotídeos marcados com fluoróforos. O sequenciamento é então dividido em etapas distintas, com uso de iniciadores com n, n-1, n-2, n-3 e n-4 bases. Usam-se sondas aleatórias marcadas com um entre os quatro fluoróforos possíveis.

Análise das sequências obtidas: foi realizada pelo colaborador Prof. Dr. Arthur Gruber (Departamento de Parasitologia- ICB/USP). As sequências foram analisadas utilizando o gene vit-6 de Oscheius tipulae (Oti-vit-6)(GenBank: U35449.2) como molde. A partir dos contigs encontrados, oligonucleotídeos específicos foram definidos através do programa Primer3Plus, disponível na Internet (http://www.bioinformatics.nl/primer3plus). Foram feitos 8 pares de 
oligonucleotídeos (foward e reverse), contando com um par de oligonucleotídeos dT17 (Tabela 3.1).

\subsubsection{Alinhamentos de sequências e produção de oligonucleotídeos}

Além dos oligonucleotídeos apresentados anteriormente, foram obtidos outros oligonucleotídeos para amplificação do gene vit-6 de H. baujardi LPP7. Para isso, foi realizado um alinhamento entre as sequências codificadoras das vitelogeninas de Oscheius tipulae (ALMENARA et al., 2013) e de Heterorhabditis bacteriophora disponíveis no projeto de ESTs (GenBank). Foram analisadas as regiões mais conservadas entre estas duas espécies e estas regiões foram utilizadas para construção de oligonucleotídeos degenedados (Tabela 3.1).

Tabela 3.1: Oligonucleotídeos iniciadores utilizados.

\begin{tabular}{|l|l|l|l|}
\hline Nome & Sequência (5'-3') & Tm $^{\circ}$ C & Utilização \\
\hline S07-A & TGGTCTGCCAATATCAAGAAA & 51,9 & RT-PCR \\
\hline S07-B & GGAACCTTGGTCTGCCAATA & 54,8 & RT-PCR \\
\hline S10-A & TGCTGATGAGATTGGCAGAC & 55,1 & RT-PCR \\
\hline S11-A & GGCAATGGAACAAGCATCTTA & 53,5 & RT-PCR \\
\hline S14-A & CCCCAATTACGGGAGAAAAT & 52,6 & RT-PCR \\
\hline S10_R-A & TTGAGGGGTTGAACAAAATTC & 51,4 & RT-PCR \\
\hline S11_R-A & TCTTAAGGAGCGAATACGTGA & 53,2 & RT-PCR \\
\hline S14_R-A & GCGATGCTTGTAAGCTTTGTT & 54,3 & RT-PCR \\
\hline S14_R-B & GACGGTTTCAGCCCTCAGTA & 56,7 & RT-PCR \\
\hline S17_R-A & CGCATAATCCACACTGCTTG & 54,3 & RT-PCR \\
\hline S17_R-B & GGAACTCGTTCTTCTTATCTCCAT & 54,2 & RT-PCR \\
\hline dT 17 & CGGATCCCGTATAATGCGCGT(17) & 60,9 & $\begin{array}{l}\text { Amplificação } \\
\text { do cDNA }\end{array}$ \\
& & & Hba-vit-6 \\
\hline $\begin{array}{l}\text { dT 17 } \\
\text { adaptador }\end{array}$ & CGGATCCCGTATAATGCGCG & 58,4 & RT-PCR \\
\hline vghb_01 & ASTGGACTTGARCAGCTMG & 54,4 & RT-PCR \\
\hline vghb_02 & AAGCTYCTCCARAAGGTYG & 53,6 & RT-PCR \\
\hline vghb_01R & ACKAGCTGYTCAAGTCCAATY & 56,5 & RT-PCR \\
\hline vghb_02R & TCRACCTTYTGGAGRAGCTT & 54,9 & RT-PCR \\
\hline vghb_3R & WGARCGYTTTCCACGSACAACKA & 60,2 & RT-PCR \\
\hline vghb_04 & GATGCYCTTGCYATS & 46,6 & RT-PCR \\
\hline vghb_05 & CYGGAACCAAGRTYA & 45,9 & RT-PCR \\
\hline vghb_06 & CTYMTTGARAAGATC & 52,4 & RT-PCR \\
\hline Universal & ACTGGCCGTCGTTTTAC & Sequenciamento \\
\hline Reverso & AACAGCTATGACGATG & 56,4 & Sequenciamento \\
\hline Promotor T7 & CCCTATAGTGAGTCGTATTA & Sequenciamento \\
\hline
\end{tabular}




\subsubsection{Produção de cDNAs de H. baujardi LPP7 e RT-PCR}

As reações de reassociação (“annealing”) para produção do cDNA foram realizadas com $5 \mu \mathrm{g}$ de RNA total e $1 \mu \mathrm{g}$ do oligonucleotídeo $\mathrm{dT}_{17}$ (Tabela 3.1) em água estéril para um volume final de $11,0 \mu \mathrm{L}$. Esta mistura foi aquecida a $65^{\circ} \mathrm{C}$ por cinco minutos para desnaturação das regiões dupla fita do RNA e oligonucleotídeos e colocada do gelo novamente. Posteriormente, foi adicionado o tampão adequado à enzima SuperScriptR II (Invitrogen) e $10 u / \mu L$ de inibidor de ribonuclease (RNaseOUT ${ }^{T M}$ - Invitrogen). O tempo de extensão foi de 50 a 60 minutos. Após este tempo, as enzimas foram inativadas durante 5 a 15 minutos a $70{ }^{\circ} \mathrm{C}$. Foram feitos controles das reações na ausência de Transcriptase Reversa. O estoque de cDNA foi armazenado a $-20{ }^{\circ} \mathrm{C}$ ou utilizado imediatamente em reações de PCR.

Para a reação de PCR foi utilizada a Dream Taq Fermentas (Thermo Scientific - Thermo Fisher Scientific Inc., Waltham, Massachusetts, Estados Unidos da América). A desnaturação foi feita inicialmente por 3 minutos a $95{ }^{\circ} \mathrm{C}$. Depois disso, foram feitos 35 ciclos de temperatura de desnaturação, reassociação e extensão, nesta ordem. Cada ciclo, teve a duração de 30 segundos a $95{ }^{\circ} \mathrm{C}$ e 30 segundos à temperatura de reassociação, que variou para cada par de iniciadores utilizados, e 1 minuto a $72{ }^{\circ} \mathrm{C}$ para cada $1000 \mathrm{pb}$ esperados no tamanho do fragmento amplificado (recomendação do fabricante da enzima). Ao final, foi utilizado um último ciclo de extensão de 10 minutos a $72{ }^{\circ} \mathrm{C}$. Alguns dos iniciadores utilizados nas reações de PCR foram obtidos a partir da análise das sequências provenientes do RNAseq. Um dos pares (degenerado) foi obtido através do alinhamento entre duas espécies próximas a H. baujardi (Tabela 3.2).

Tabela 3.2: Pares de oligonucleotídeos utilizados nos ensaios de RT-PCR.

\begin{tabular}{|l|l|l|}
\hline Pares & $\begin{array}{l}\text { Temperatura de } \\
\text { reassociação utilizada }\end{array}$ & $\begin{array}{l}\text { Tamanho esperado do } \\
\text { fragmento }\end{array}$ \\
\hline S07-A e S10_R-A & $52^{\circ} \mathrm{C}$ & $1110 \mathrm{pb}$ \\
\hline S07-B e S11_R-A & $55^{\circ} \mathrm{C}$ & $1830 \mathrm{pb}$ \\
\hline S07-B e S14_R-A & $55^{\circ} \mathrm{C}$ & $3000 \mathrm{pb}$ \\
\hline S07-B e S17_R-A & $55^{\circ} \mathrm{C}$ & $4140 \mathrm{pb}$ \\
\hline S10-A e S14_R-B & $55^{\circ} \mathrm{C}$ & $2280 \mathrm{pb}$ \\
\hline S11-A e S14_R-B & $55^{\circ} \mathrm{C}$ & $1620 \mathrm{pb}$ \\
\hline S14-A e S17_R-B & $55^{\circ} \mathrm{C}$ & $1170 \mathrm{pb}$ \\
\hline S14-A e dT17adaptador & $58^{\circ} \mathrm{C}$ & $1900 \mathrm{pb}$ \\
\hline vghb 04 e vghb 03R & $58^{\circ} \mathrm{C}$ & $1300 \mathrm{pb}$ \\
\hline
\end{tabular}




\subsubsection{Eletroforese de DNA em gel de agarose}

Amostras de DNA foram analisadas por eletroforese em gel de agarose $1 \%(\mathrm{~m} / \mathrm{v})$ e $2 \%$ $(\mathrm{m} / \mathrm{v})($ em casos onde o fragmento a ser visto era menor do que 300pb) na presença de tampão de corrida TAE com voltagem constante de aproximadamente $90 \mathrm{~V}$. Para a eletroforese, foi adicionado tampão de amostra para DNA $6 \mathrm{X}$ e água às amostras. O DNA foi corado com Brometo de Etídeo (EtBr) 0,5 $\mu \mathrm{g} / \mathrm{mL}$ e as bandas foram detectados em transiluminador de luz ultra-violeta. O registro dos resultados foi feito em aparelho de captura de imagens, ImageQuant 350 (GE Healthcare Lifesciences, Uppsala, Suécia).

\subsubsection{Plasmídeos}

Os plasmídeos utilizados durante o trabalho foram:

- pCR2.1-TOPO®, Invitrogen ${ }^{T M}$ Life Technologies - plasmídeo de 3.098 pb, com marca de resistência para ampicilina. Utilizado para clonagem de produtos de PCR. Trata-se de um plasmídeo linear complexado com moléculas de DNA topoisomerase I do vírus de Vaccínia ligadas às suas pontas 3' com timidinas livres. Isso permite a ligação do DNA do plasmídeo às extremidades com adeninas livres de fragmentos amplificados (SHUMAN, 1994).

- pGEM - plasmídeo de 3000 pb, com marca de resistência para ampicilina. Utilizado na clonagem de produtos de PCR. É um plasmídeo linearizado na base de número 60 a partir de restrição com enzima ECORV e possui uma Timina em ambas as extremidades. $\mathrm{O}$ sítio de restrição de ECORV não é recuperado após ligação com o fragmento de inserção.

\subsubsection{Clonagem de Produto de PCR}

Os produtos de PCR foram utilizados diretamente após a reação ou, no caso de PCRs com presença de bandas inespecíficas, a banda majoritária foi cortada do gel de agarose com bisturi, sob luz U.V. e eluída com kit QIAquick $囚$ Gel Extraction Kit (QIAGEN, Valencia, California, Estados Unidos da América), segundo as especificações do fabricante. Para a ligação, o produto de PCR foi adicionado a $100 \mathrm{ng}$ do plasmídeo em $\mathrm{NaCl} 50 \mathrm{mM}$ e $\mathrm{MgCl} 2$ 2,5 mM e a reação foi incubada a temperatura ambiente $\left(25^{\circ} \mathrm{C}\right.$ ) por 20 minutos (em TOPO) ou por 1 hora, também a temperatura ambiente (em pGEM). O fragmento de DNA amplificado foi adicionado à reação de ligação seguindo a proporção de excesso molar de cerca de três vezes em relação à quantidade 
de vetor. O produto da reação de ligação foi usado para transformação de bactérias quimio competentes, como descrito no item 3.1.3.

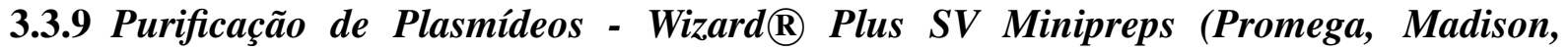 Wisconsin, Estados Unidos da América)}

1,5 ml de suspensão de bactérias transformadas e crescidas em meio $L B$ adicionado do antibiótico de interesse foram centrifugados por 30 segundos a $10.000 \mathrm{~g}$ e o meio de cultura foi removido. As bactérias foram ressuspendidas em solução para ressuspenssão de células. A solução de lise foi então adicionada à amostra, sendo acrescida de protease alcalina (200 mg por amostra). Após cinco minutos à temperatura ambiente, adicionou-se a solução neutralizante. Centrifugou-se a 10.000 g por 10 minutos à temperatura ambiente. O sobrenadante foi transferido para uma coluna e centrifugado (10.000 g por um minuto). A coluna foi lavada duas vezes com tampão de lavagem. O DNA plasmidial foi eluído com água após centrifugação da coluna a 10.000 g por um minuto à temperatura ambiente.

\subsubsection{Purificação de Plasmídeos com Cloreto de Lítio}

1,5 ml de suspensão de bactérias transformadas e crescidas em meio LB líquido adicionado do antibiótico de interesse foram centrifugados por 30 segundos a $10.000 \mathrm{~g}$ e o meio de cultura foi removido. As bactérias foram ressuspendidas em TELT e a elas foi adicionado $100 \mu \mathrm{l}$ de fenol clorofórmio. As amostras foram agitadas em Vortex por 5 segundos e incubadas por 15 minutos a temperatura ambiente para lise das bactérias. Depois disso, foram centrifugadas por um minuto a $10.000 \mathrm{~g}$, temperatura ambiente. O sobrenadante foi coletado e adicionado de dois volumes de etanol absoluto e centrifugado a $4{ }^{\circ} \mathrm{C}$ por 10 minutos a $15.000 \mathrm{~g}$. O DNA precipitado foi lavado com etanol 70\%, centrifugado nas mesmas condições anteriores, seco sob vácuo em speed vac SC100 Savant (GMI, Inc., Ramsey, Minnesota, Estados Unidos da América) e ressuspendido em $T E$ contendo Rnase A $(20 \mu \mathrm{g} / \mathrm{ml})$.

\subsubsection{Sequenciamento de DNA}

As sequências foram obtidas utilizando-se o protocolo de "Cycle Sequencing", com o kit

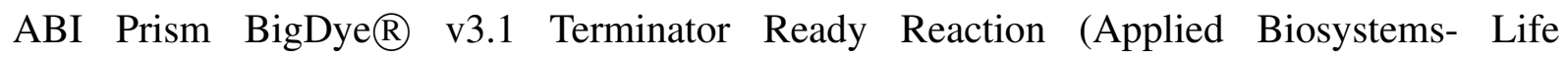
Technologies, Carlsbad, California, Estados Unidos da América), baseado no método de sequenciamento enzimático de DNA (SANGER et al., 1977). As análises foram realizadas com auxílio do programa DNAStar (Lasergene). Os alinhamentos foram realizados através do 
programa CLUSTAL W 2.0 (LARKIN et al., 2007).

\subsection{Purificação e Análise de Proteínas}

\subsubsection{Purificação de vitelogenina}

Os vermes congelados em nitrogênio líquido foram moídos e ressuspendidos em tampão de homogeneização $2 X(T H 2 X)$ contendo os inibidores de proteases PMSF $1 \mathrm{mM}$, pepstatina 20 $\mu M$ e E-64 $20 \mu M$. O homogeneizado foi centrifugado a $1.500 \mathrm{xg}$ durante 5 minutos à $4{ }^{\circ} \mathrm{C}$. O sobrenadante foi então diluído 2 vezes em TH $1 \mathrm{X}$ contendo os mesmos inibidores de protease, e centrifugado a $40.500 \mathrm{xg}$ durante 15 minutos a $4{ }^{\circ} \mathrm{C}$.

Cromatografias: todas as análises cromatográficas foram feitas num sistema "Äkta prime plus" (GE Healthcare) e o registro de absorbância das frações foi realizado em $280 \mathrm{~nm}$.

Cromatografia de afinidade em coluna de Con A-Sepharose: o sobrenadante da última centrifugação descrita no item anterior foi filtrado em filtro de fibra de vidro GF/A (Whatman GE Healthcare) e novamente em filtro Millipore (Merck Millipore - Merck KGaA, Darmstadt, Alemanha) de 0.22 um. A amostra filtrada foi então aplicada à uma coluna de Concanavalina-A-sepharose (HiTrap Com A 4B- GE Healthcare) em TH $1 X$, com inibidores de proteases (PMSF $1 \mathrm{mM}$; pepstatina $20 \mu M$; E-64 $20 \mu M$ ), num fluxo de 0,3 mL/min. A coluna foi lavada com $T H 1 X$ num fluxo de $0,5 \mathrm{~mL} / \mathrm{min}$. As proteínas ligadas à coluna foram eluídas com $T H 1 X$ contendo $\alpha$-metil-manosídeo $0,5 \mathrm{M}$ e inibidores de proteases num fluxo de 0,5 $\mathrm{mL} / \mathrm{min}$. Uma alíquota de $50 \mu L$ de cada uma das frações eluídas da coluna foram precipitadas com ácido tricloroacético (TCA) 10\% (p/v). O precipitado foi lavado com acetona, seco sob vácuo e dissolvido em tampão de amostra para SDS-PAGE e analisado em gel com T=10\%.

Coluna de Troca Iônica: para realizar a troca iônica e obter vitelogenina em um estado mais puro, foi usada uma coluna de troca aniônica (HiTrap ${ }^{T M}$ Q FF- GE Healthcare). As frações obtidas na cromatografia de afinidade em Con A-Sepharose, que continham as bandas de vitelogenina, foram reunidas, dialisadas contra Tris $(20 \mathrm{mM})$-EDTA $(1 \mu M)$ e aplicadas à coluna de troca iônica em Tris $20 \mathrm{mM}$ num fluxo de $1 \mathrm{~mL} / \mathrm{min}$. As proteínas adsorvidas à coluna foram eluídas com um gradiente de 0,1 a $1 \mathrm{M}$ de $\mathrm{NaCl}$ em tampão de eluição (Tris $20 \mathrm{mM}$; $\mathrm{NaCl} 1 \mathrm{M}$ ) num fluxo de $1 \mathrm{~mL} / \mathrm{min}$. Uma alíquota de cada uma das frações do perfil cromatográfico foi precipitada com ácido tricloroacético (TCA) $10 \%$ (p/v). O precipitado foi lavado com acetona, seco e dissolvido em tampão de amostra para SDS-PAGE e analisado em gel com $\mathrm{T}=10 \%$. 


\subsubsection{Eletroforese de proteína em gel de poliacrilamida na presença de SDS (SDS-PAGE)}

As eletroforeses foram realizadas em cuba Mini-Protean II Cell (Bio-Rad, Hercules, California, Estados Unidos da América), em gel de concentração simples $(\mathrm{T}=10 \%)$ a 12,4 Volts/cm por aproximadamente 2 horas, a $25{ }^{\circ} \mathrm{C}$, em tampão de corrida para SDS-PAGE. As proteínas foram dissolvidas em tampão de amostra (WINTER, 1992). As amostras foram aquecidas a $96{ }^{\circ} \mathrm{C}$ durante 5 minutos, centrifugadas a $10000 \mathrm{xg}$ por 1 minuto e o sobrenadante aplicado aos poços no gel de empilhamento. Para se detectar as proteínas separadas por eletroforese, as bandas foram fixadas e coradas de acordo com o método de Schägger e Jagow (1987). Primeiramente o gel foi fixado em uma solução contendo metanol 50\% (v/v) e ácido acético 10\% (v/v) por 30 minutos. A coloração foi feita com Coomasie Blue R-350 (PhastGel Blue; GE LifeSciences, Piscataway, New Jersey, Estados Unidos da América) 0,025\% (p/v), dissolvido em metanol: ácido acético: água (33:9:58; v/v/v) contendo CuSO4 0,1\% (p/v), como descrito pelo fabricante. A descoloração do gel foi realizada em ácido acético 7\% (v/v).

\subsubsection{Eluição de peptídeos de gel de poliacrilamida}

A amostra obtida da purificação descrita no item 3.4.1 foi aplicada a um gel de poliacrilamida preparativo $\mathrm{T}=12 \%$, com as dimensões: $\mathrm{A} 8 \mathrm{~cm} \times \mathrm{C} 14 \mathrm{~cm} \times \mathrm{L} 2 \mathrm{~mm}$. A eletroforese foi realizada a 12,4 Volts/cm por aproximadamente 6 horas. A tira de gel correspondente ao padrão e mais uma tira correspondente às amostras foram cortadas do resto do gel e coradas com Comassie Blue, para a detecção da altura das bandas. As duas partes foram colocadas lado a lado e as bandas correspondentes a cada polipeptídeo foram cortadas com bisturi. O material de cada banda foi então aplicado a um sistema de eletroeluição. $\mathrm{O}$ procedimento foi realizado em um sistema de microeletroeluidor em cuba Mini Trans-Blot $\mathbb{R}$ Cell (Bio-Rad). As bandas foram eluídas por 5 horas em corrente constante de $10 \mathrm{~mA}$, em tampão de eluição.

\subsubsection{Antissoros}

Os antissoros foram obtidos por imunização de três camundongos machos da linhagem Balb/c para cada peptídeo (total de nove camundongos imunizados). Foram utilizados para inoculação os peptídeos VT1, VT2 e VT3 purificados (ver item 3.4.3). Os peptídeos foram emulsionados em adjuvante de Freund completo (Sigma-Aldrich, St. Louis, Missouri, Estados Unidos da América) e $100 \mu l$ da emulsão foram injetados no dorso do animal, na região subcutânea utilizando seringa de vidro e agulha 18G1. Decorrido um mês do inóculo inicial 
foi injetada uma segunda dose de reforço com os mesmos peptídeos, dessa vez emulsionados em adjuvante de Freund incompleto (Sigma-Aldrich). Quinze dias após o reforço os animais foram anestesiados e sangrados pelo plexo axilar, sendo sacrificados imediatamente em seguida. O sangue foi coletado em tubos de $1,5 \mathrm{ml}$, mantidos a $37^{\circ} \mathrm{C}$ por 30 minutos e a $4{ }^{\circ} \mathrm{C}$ por cinco minutos para coagulação. O coágulo foi centrifugado a $10000 \mathrm{~g}$ por dois minutos à temperatura ambiente e o soro foi coletado, sendo então armazenado a $-20{ }^{\circ} \mathrm{C}$. Detalhes do procedimento de anestesia e sacrifício dos animais foram apresentados à comissão de ética responsável, e seguiram as recomendações do COBEA (Colégio Brasileiro de Experimentação Animal). Havia um décimo indivíduo que não foi inoculado, servindo de controle (soro não-imune).

\subsection{5 "Western blot"}

As proteínas fracionadas por SDS-PAGE foram transferidas para membranas de nitrocelulose Hybond $(\mathrm{A}-\mathrm{C}$ Extra (Amersham- GE Healthcare) em cuba de transferência

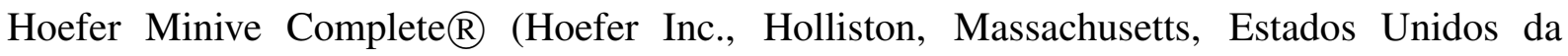
América) em tampão de transferência, submetida a $25 \mathrm{~V}$ por 2 horas a $4{ }^{\circ} \mathrm{C}$. A membrana foi corada com Ponceau $S$, para identificação das bandas e corte das tiras. As tiras de membrana contendo as proteínas fracionadas foram incubadas em $P B S I X$ adicionado de leite em pó desnatado $5 \%(\mathrm{~m} / \mathrm{v})$ (PBS-leite) por duas horas em temperatura ambiente sob agitação

constante. Após esse período de "bloqueio" da membrana, esta foi incubada com PBS-leite adicionado do antissoro mono-específico durante 16 horas a $4{ }^{\circ} \mathrm{C}$ sob agitação constante. A membrana foi lavada três vezes em PBS durante quinze minutos. Após as lavagens, a membrana foi incubada, sob agitação, com PBS-leite contendo anti-IgG de camundongo conjugada à peroxidase (Sigma-Aldrich) na diluição 1:2000 durante duas horas à temperatura ambiente. Os três ciclos de lavagem foram repetidos e as bandas reconhecidas pelo anticorpo foram reveladas com 4-cloro-1-naftol $0,5 \mathrm{mg} / \mathrm{ml} \mathrm{em} \mathrm{metanol} \mathrm{0,17 \%} \mathrm{(v/v)} \mathrm{na} \mathrm{presença} \mathrm{de}$ $\mathrm{H} 2 \mathrm{O} 2$ 0,015\% (v/v). Essa reação foi interrompida pela adição de água.

\subsection{Lista de Soluções}

\begin{tabular}{|l|l|}
\hline Solução & Composição \\
\hline Meio $L B$ & Triptona $1 \%(\mathrm{~m} / \mathrm{v}) ;$ Extrato de Levedura \\
& $0,5 \%(\mathrm{~m} / \mathrm{v}) ; \mathrm{NaCl} 170 \mathrm{mM}$. \\
\hline
\end{tabular}




\begin{tabular}{|c|c|}
\hline Solução & Composição \\
\hline Meio LB agar piruvato & $\begin{array}{l}\text { Triptona } 1 \%(\mathrm{~m} / \mathrm{v}) ; \text { Extrato de Levedura } \\
0,5 \%(\mathrm{~m} / \mathrm{v}) ; \mathrm{NaCl} 170 \mathrm{mM} \text {; Bacto-agar } \\
2,5 \%(\mathrm{~m} / \mathrm{v}) ; \text { Piruvato } 0,1 \%(\mathrm{v} / \mathrm{v})\end{array}$ \\
\hline Meio FLA & $\begin{array}{l}\text { Nutrient } \text { Agar }^{7} 2 \%(\mathrm{~m} / \mathrm{v}) \text {; Óleo de milho } \\
1 \%(\mathrm{v} / \mathrm{v}) ; \text { Colesterol 0,5\% (m/v) }\end{array}$ \\
\hline$P B S$ & $\begin{array}{l}\mathrm{Na} 2 \mathrm{HPO} 416 \mathrm{mM} ; \mathrm{NaH} 2 \mathrm{PO} 44 \mathrm{mM} \text {; } \\
\mathrm{NaCl} 150 \mathrm{mM}\end{array}$ \\
\hline Ponceau $S$ & $\begin{array}{l}\text { Ponceau S 0,5\% (m/v); Ácido Acético } 1 \% \\
(\mathrm{v} / \mathrm{v})\end{array}$ \\
\hline $\begin{array}{l}\text { Solução de lise (extração de } \\
\text { plasmídeo) }\end{array}$ & $\mathrm{NaOH} 0,2 \mathrm{M} ; \mathrm{SDS} 1 \%$ \\
\hline $\begin{array}{l}\text { Solução neutralizante (extração de } \\
\text { plasmídeo) }\end{array}$ & $\begin{array}{l}\text { Hidrocloreto de guanidina } 4,09 \mathrm{M} \text {; } \\
\text { Acetato de potássio } 0,759 \mathrm{M} ; \text { Ácido } \\
\text { acético glacial 2,12M }\end{array}$ \\
\hline $\begin{array}{l}\text { solução para ressuspenssão de } \\
\text { células (extração de plasmídeo) }\end{array}$ & $\begin{array}{l}\text { Tris-HCl } 50 \mathrm{mM}(\mathrm{pH} 7,5) \text {; EDTA } 10 \mathrm{mM} \text {; } \\
\text { RNAse A } 100 \mu \mathrm{g} / \mathrm{ml}\end{array}$ \\
\hline$T A E 1 x$ & Tris 40 mM; EDTA 1 mM pH 7,5 \\
\hline Tampão de Amostra para DNA $6 X$ & $\begin{array}{l}\text { Azul de bromofenol } 0,25 \%(\mathrm{~m} / \mathrm{v}) \text {, } \\
\text { Xilenocianol } 0,25 \%(\mathrm{~m} / \mathrm{v}) \text { e Ficoll } 15 \% \\
(\mathrm{~m} / \mathrm{v})\end{array}$ \\
\hline Tampão de amostra para proteína & $\begin{array}{l}\text { Tris-HCl 62,5 mM pH 6.8; glicerol } \\
20 \% \quad(\mathrm{v} / \mathrm{v}) ; \text { EDTA } 0,5 \mathrm{mM} \text {, azul de } \\
\text { bromofenol } 0,015 \% \quad(\mathrm{v} / \mathrm{v}) ; \text { DTT } 62,4 \\
\text { mM ou 2-mercaptoetanol 2,5\% (v/v) } \\
\text { (WINTER, 1992) }\end{array}$ \\
\hline $\begin{array}{l}\text { Tampão de corrida para } \\
\text { SDS-PAGE }\end{array}$ & $\begin{array}{l}\text { Tris } 25 \mathrm{mM} \text { pH 8,3; glicina } 192 \mathrm{mM} \text {; SDS } \\
0,1 \%(\mathrm{~m} / \mathrm{v})\end{array}$ \\
\hline $\begin{array}{l}\text { Tampão de eluição para } \\
\text { eletroeluição }\end{array}$ & $\begin{array}{l}\text { Tris } 25 \mathrm{mM} \text { pH 8,3; glicina } 192 \mathrm{mM} \text {, SDS } \\
1 \%(\mathrm{~m} / \mathrm{v})\end{array}$ \\
\hline $\begin{array}{l}\text { tampão de lavagem (extração de } \\
\text { plasmídeo) }\end{array}$ & $\begin{array}{l}\text { Acetato de potássio } 60 \mathrm{mM} \text {; Tris- } \mathrm{HCl}(\mathrm{pH} \\
7,5) 8,3 \mathrm{mM} \text {; EDTA }(\mathrm{pH} 8,0) 0,04 \mathrm{mM} \text {; } \\
\text { Etanol } 60 \%(\mathrm{v} / \mathrm{v})\end{array}$ \\
\hline
\end{tabular}

\footnotetext{
${ }^{7}$ Composição do Nutrient Agar: Peptona de carne 5g/L; Extrato de carne 3g/L; Agar agar 12g/L.
} 


\begin{tabular}{|c|c|}
\hline Solução & Composição \\
\hline transferência para Western-blot & $\begin{array}{l}\text { Tris } 62,5 \mathrm{mM} \mathrm{pH} \mathrm{8,3;} \mathrm{glicina} 0,48 \mathrm{M} \text {, } \\
\text { Metanol } 20 \%(\mathrm{v} / \mathrm{v})\end{array}$ \\
\hline Tampão $S$ & $\begin{array}{l}\text { Tampão fosfato } 50 \mathrm{mM} \mathrm{pH} \mathrm{6,0;} \mathrm{NaCl} 100 \\
\mathrm{mM}\end{array}$ \\
\hline Tатра̃o M9 & $\begin{array}{l}\text { KH2PO4 } 22 \mathrm{mM} \text {; Na2HPO4 x } 12 \mathrm{H} 2 \mathrm{O} \\
16,7 \mathrm{mM} ; \mathrm{NaCl} 85,5 \mathrm{mM} ; \mathrm{MgSO} 41 \mathrm{mM}\end{array}$ \\
\hline$T E$ & Tris $10 \mathrm{mM} \mathrm{pH} 8,0$; EDTA $1 \mathrm{mM}$ \\
\hline TELT & $\begin{array}{l}\text { Tris } 50 \mathrm{mM} \text { pH 8,0; EDTA } 62,5 \mathrm{mM} \text {; } \\
\mathrm{LiCl} 2,5 \mathrm{M} \text {; Triton X-100 4\% (v/v) }\end{array}$ \\
\hline TES & $\begin{array}{l}\text { Tris } 10 \mathrm{mM} \mathrm{pH} \mathrm{7,4;} \mathrm{EDTA} 5 \mathrm{mM} \text {; SDS } \\
1,0 \%\end{array}$ \\
\hline $\begin{array}{l}\text { Tampão de Homogeneização } \\
\text { (extração de RNA) }\end{array}$ & $\begin{array}{l}\text { Tiocianato de guanidina 4,5M; Tris- } \mathrm{HCl} \\
25 \mathrm{mM} \text { pH 7,5; 2-mercaptoetanol } 0,72 \% \\
(\mathrm{p} / \mathrm{v}) ; \text { sarcosil } 1 \%(\mathrm{p} / \mathrm{v})\end{array}$ \\
\hline TH $2 X$ (purificação de proteína) & $\begin{array}{l}\text { Tris } 40 \text { mM pH 7.4; CaCl2 } 2 \text { mM; } \mathrm{MnCl} 2 \\
2 \text { mM; } \mathrm{NaCl} 1,2 \mathrm{M}\end{array}$ \\
\hline
\end{tabular}




\section{RESULTADOS}

\subsection{Cultura de nematoides em massa}

\subsubsection{Manutenção da cultura de $\mathrm{H}$. baujardi $L P P 7$ in vitro}

O cultivo in vitro de nematoides entomopatogênicos já foi estabelecido há décadas por outros autores, e atualmente é utilizado em diversas áreas de estudos destes animais (ver item 5.1). Porém, foi durante os meses inicias deste projeto que a cultura in vitro foi estabelecida em nosso laboratório. Este resultado foi importante por proporcionar a obtenção de fêmeas jovens e maduras em quantidade suficiente para todos os ensaios propostos no projeto, o que seria inviável e até impossível de se obter utilizando o cultivo in vivo, através de infecções em G. mellonella. Fêmeas retiradas de insetos 3 dias após a infecção não atendem à demanda necessária para os ensaios propostos neste projeto. O ciclo de vida completo de $H$. baujardi LPP7 in vitro é mostrado na Figura 4.1.

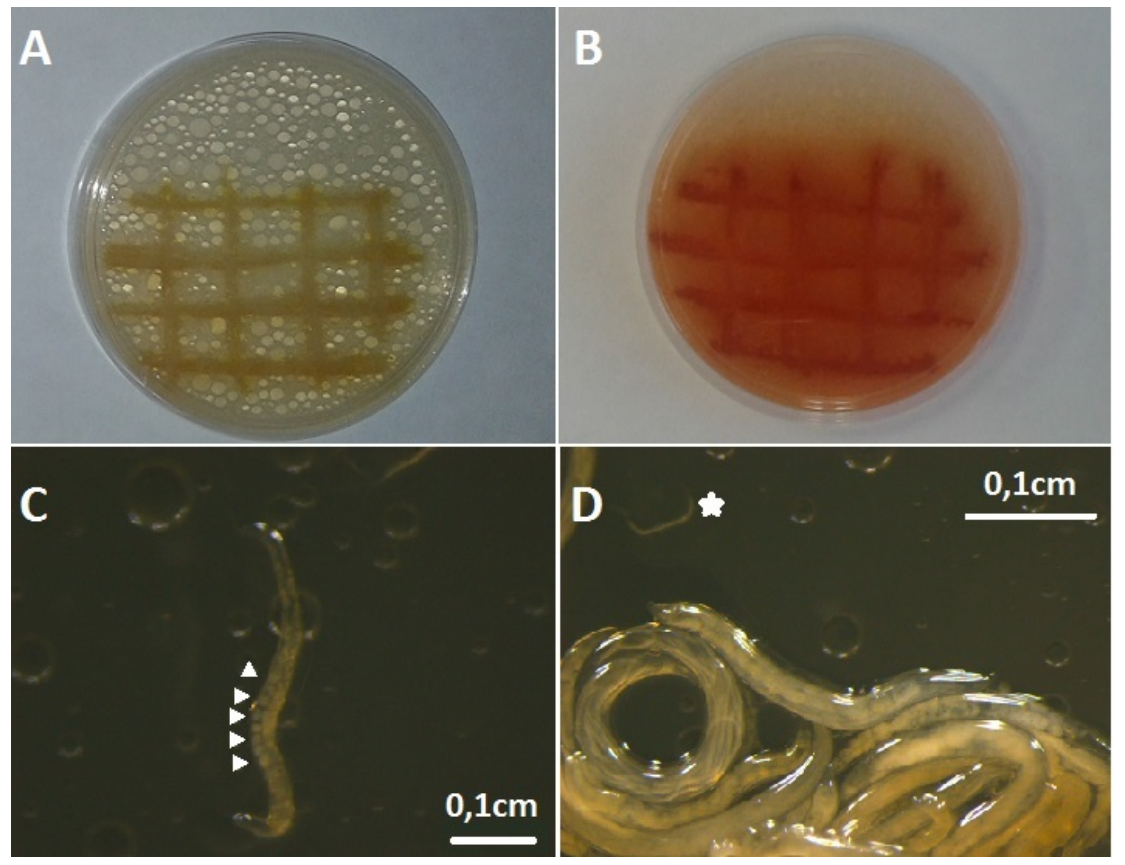

Figura 4.1: Ciclo de vida de H.baujardi LPP7 in vitro. (A) Bactérias da linhagem MN7 de P. luminescens foram plaqueadas em meio de extrato de carne. (B) Um dia após a inoculação da bactéria (notar o acúmulo de pigmento na placa contendo óleo de milho), Jis de LPP7 lavados com hipoclorito de sódio foram adicionados às placas. (C) Fêmeas protrândricas de $1^{\text {a }}$ geração com ovos (setas brancas). (D) Fêmeas "sofrendo" o processo de Endotoquia Matricida, com larvas eclodidas em seu interior. $O$ asterisco branco mostra uma larva recém eclodida, de tamanho bem reduzido em relação ao adulto. 


\subsubsection{Taxa de infectividade de nematoides mantidos in vitro}

Apesar da alta eficiência da cultura in vitro para obtenção de fêmeas, é inviável manter apenas este tipo de cultura em laboratório. Foi observado durante alguns meses de cultivo (7 gerações sucessivas em placa - dados não mostrados) que a infectividade da simbiose nematoide-bactéria não se mantém (Figura 4.2). Por isso, a propagação in vivo do nematoide, utilizando larvas de G. mellonella, é necessária para manutenção da linhagem a longo prazo.

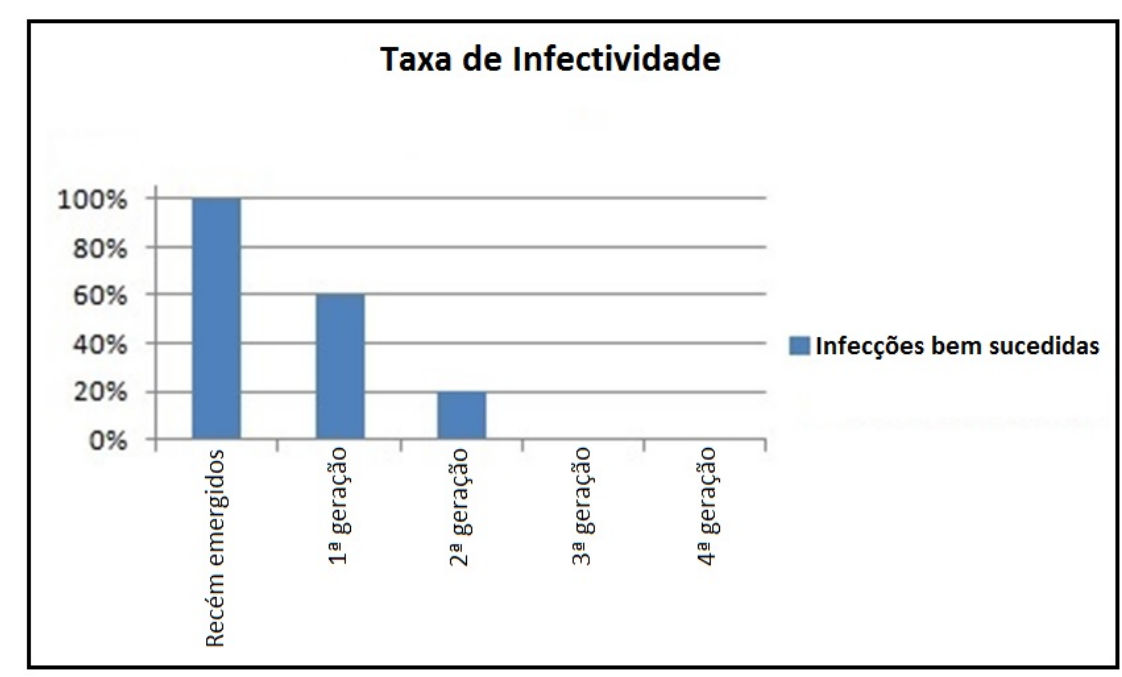

Figura 4.2: Taxa de Infectividade de $H$. baujardi LPP7 mantido in vitro por quatro gerações. $O$ primeiro valor mostra a infectividade alcançada por nematoides mantidos in vivo em larvas de G. mellonella, recém emergidos. Os valores seguintes referem-se à cada geração mantida em placa na presença da bactéria simbionte P. luminescens MN7. Apenas as quatro primeiras gerações foram mostradas. A porcentagem foi calculada a partir da contagem de larvas infectadas em um grupo de 10 larvas em placas separadas. Os experimentos foram feitos em duplicata e apresentaram os mesmos resultados. A presença de infecção foi considerada para larvas infectadas com emergência de Jis após 17 dias da infecção (ciclo de vida completo).

\subsubsection{Manutenção da especificidade da simbiose in vitro}

Para testar se a simbiose nematoide-bactéria se mantinha específica, mesmo sem a necessidade de infecção de um hospedeiro, tentamos alimentar os nematoides crescidos in vitro com outras bactérias, não simbiontes. As tentativas foram feitas utilizando as linhagens NA22 de Escherichia coli, e a linhagem MN12 de Photorhabdus luminescens ${ }^{8}$ e, em nenhum dos dois casos, o Ji se desenvolveu em placa. Isso significa que mesmo, mesmo in vitro, a simbiose se mantém extremamente específica, fazendo com que o nematoide não se

\footnotetext{
${ }^{8}$ A linhagem MN12 é simbionte do nematoide Heterorhabditis indica, linhagem LPP12. Este nematoide também é mantido em nosso laboratório e possui exatamente as mesmas características de ciclo de vida de H. baujardi LPP7, apresentando inclusive o mesmo tempo de infecção quando mantido em larva de Galleria mellonella.
} 
desenvolva na presença de outra bactéria que não seja a sua linhagem simbionte.

\subsection{Purificação da Vitelogenina}

\subsubsection{SDS-PAGE de verme inteiro}

Aproximadamente $80 \mu \mathrm{g}$ de vermes adultos de primeira geração (hermafroditas com ovos) foram congeladas em nitrogênio líquido. O descongelamento foi feito com tampão de amostra 2X (1 volume- $80 \mu L)$ e a amostra foi fervida por 5 min antes da aplicação em gel de poliacrilamida. A Figura 4.3 mostra as bandas obtidas neste ensaio, com a posição de três polipeptídeos do vitelo em discreta maioria. As massas moleculares foram estimadas através da curva padrão construída, e são aproximadamente: 160 kDa, 110 kDa e 90 kDa. O padrão de vitelinas de $H$. baujardi LPP7 se parece com o das vitelinas do nematoide Oscheius tipulae (ALMENARA et al., 2013) (Figura 4.3B)

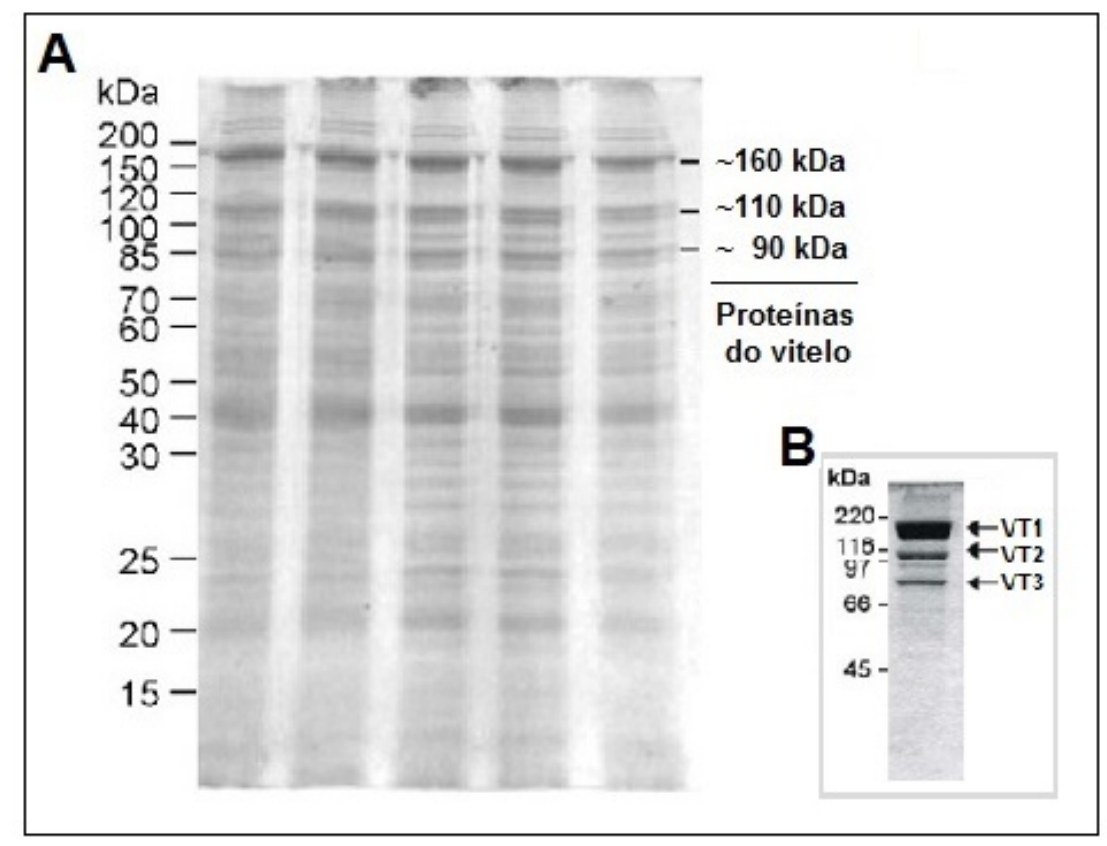

Figura 4.3: SDS-PAGE de verme inteiro. (A) Hermafroditas adultos de primeira geração foram descongelados em tampão de amostra, fervidos por 5 min e aplicados em gel de poliacrilamida. As três bandas em discreta maioria referem-se aos polipeptídeos de VTG. O padrão destes polipeptídeos se parece com o dos polipeptídeos de VTG de $O$. tipulae (B).

\subsubsection{Purificação das proteínas de vitelo}

A purificação dos polipeptídeos do vitelo foi realizada a partir de aproximadamente 7 gramas de vermes inteiros congelados e homogeneizados seguida de cromatografia de afinidade 
em Con A-Sepharose (ver item 3.4.1). A absorbância das frações foi registrada juntamente com a posição das frações (resultados não apresentados). Foram obtidas 68 frações, das quais 8 frações não consecutivas foram escolhidas para análise por SDS-PAGE. A Figura 4.4 mostra a análise por SDS-PAGE do "pool" destas frações. Podemos observar três bandas referentes aos três polipeptídeos de vitelo de $H$. baujardi LPP7. As proteínas de vitelo aparecem de forma majoritária em relação a outras glicoproteínas purificadas por afinidade.
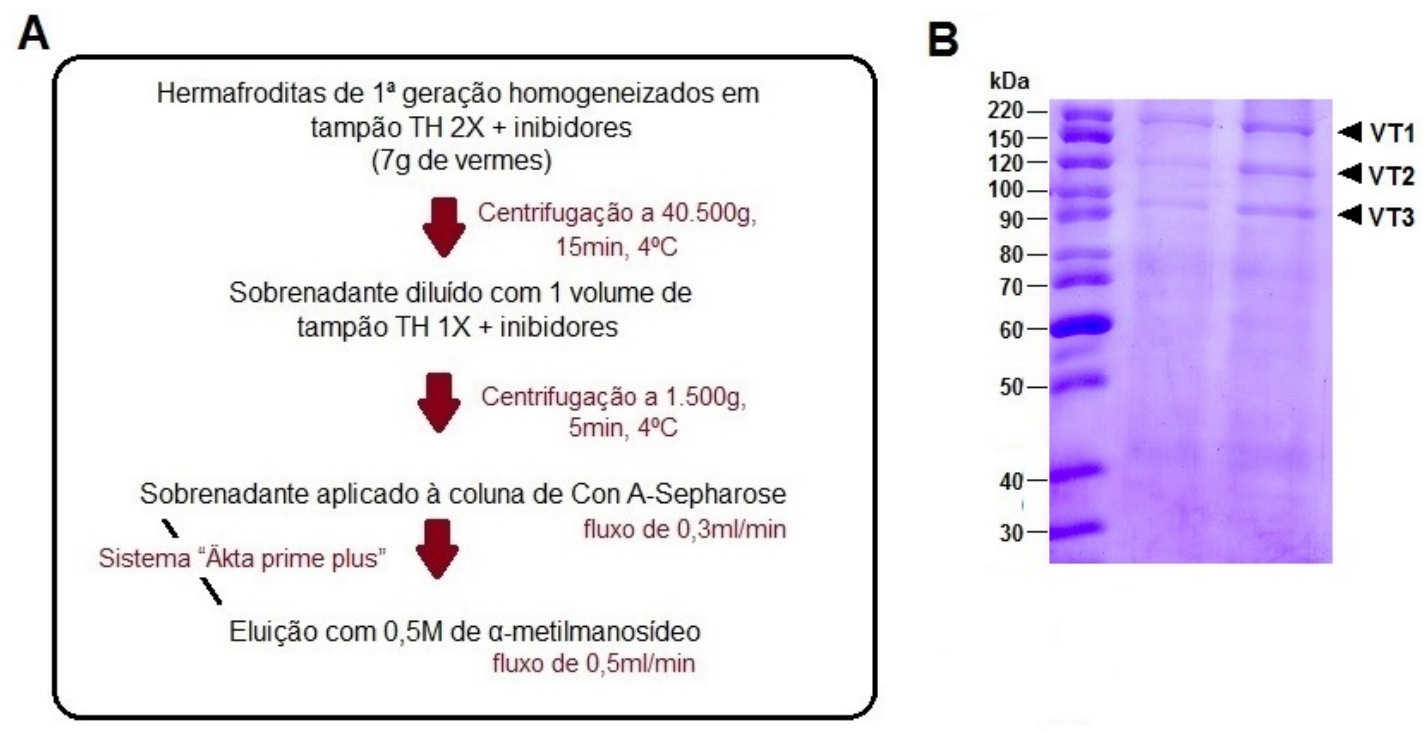

Figura 4.4: Purificação das vitelogeninas de H. baujardi LPP7 por cromatografia de afinidade em Con A-Sepharose. (A) Esquema dos passos resumidos da purificação por cromatografia de afinidade em coluna de Con A-Sepharose. (B) SDS-PAGE do "pool" de frações contendo as vitelinas. As bandas foram coradas com Comassie Blue ( $T=10 \%)$

As frações que continham os polipepeptídeos eluídos foram dialisadas contra Tris (20 mM) -EDTA $(1 \mu M)$ e aplicadas à coluna de troca iônica aniônica, para uma maior purificação das proteínas do vitelo. Os picos que contém os polipeptídeos de VTG referem-se à eluição em concentração de 0,3M de $\mathrm{NaCl}$ (Figura A.1 - Apêndice). A análise das amostras por SDS-PAGE mostra quase que exclusivamente três polipeptídeos de VTG (Figura 4.5).

\subsubsection{Separação dos polipeptídeos de vitelogenina por eletroeluição de gel de poliacrilamida}

O conteúdo da amostra obtida na última cromatografia foi precipitado com TCA, lavado quatro vezes com acetona, seco e dissolvido em tampão de amostra para SDS-PAGE. A amostra foi então aplicada em um gel de poliacrilamida preparativo. As três bandas foram cortadas e separadas com bisturi e cada uma delas foi eluída por 5 horas em corrente constante de $10 \mathrm{~mA}$. Uma alíquota de cada amostra foi analisada por SDS-PAGE para confirmação da pureza dos polipeptídeos. A Figura 4.6 mostra o gel de poliacrilamida com os polipeptídeos separados. Neste gel, pode-se observar duas bandas na amostra de VT1 que não puderam ser observadas 


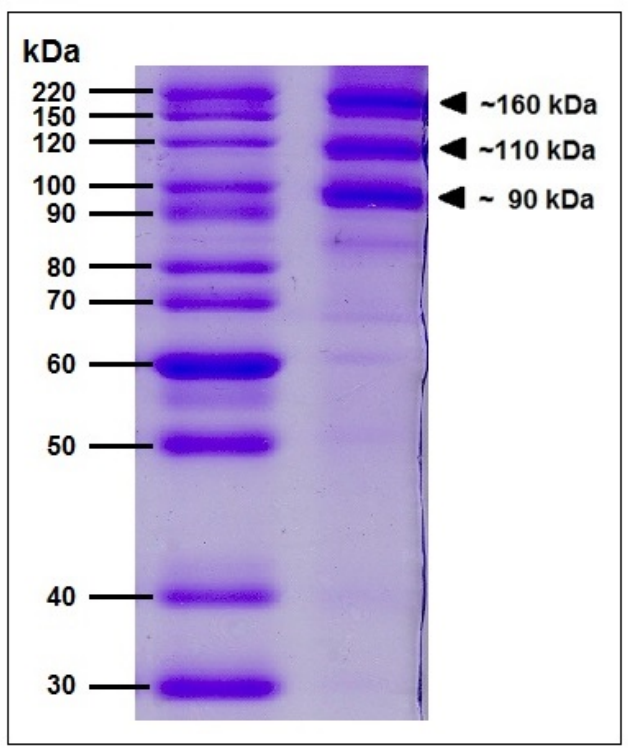

Figura 4.5: SDS-PAGE da purificação das bandas de VTG por cromatografia de troca iônica. A amostra proveniente da cromatografia de afinidade foi dialisada e nova cromatografia foi realizada para maior purificação dos polipeptídeos de vitelogenina. As bandas foram coradas com Comassie Blue $(T=12 \%)$

em ensaios anteriores, devido provavelmente à grande quantidade de amostra aplicada no gel. Este padrão é o mesmo encontrado em C. elegans (BLUMENTHAL et al., 1984), e é o contrário do que acreditávamos sobre ser parecido com o que ocorre em Oscheius tipulae (ALMENARA et al., 2013). É possível que em LPP7 esses sejam os dois polipeptídeos homólogos a YP170A e YP170B.

\subsection{Produção de antissoros}

As três amostras com os polipeptídeos de VTG purificados (ver item anterior) foram utilizadas para tentativa de obtenção de anticorpos monoespecíficos para cada polipeptídeo, em camundongos machos da linhagem Balb/C (ver item 3.4.4). Os soros foram obtidos após 45 dias e testados por Western-blot. A Figura 4.7 mostra as membranas de Western-blot. Foram três camundongos imunizados com cada amostra (cujos soros foram numerados de $1 \mathrm{a}$ 9), e um camundongo não imunizado (soro de número 10). Apenas o soro número 7 , proveniente da imunização com polipeptídeo VT3, mostrou um resultado satisfatório, sem resposta imune inespecífica. Os soros 1, 2 e 3, proveniente da imunização com VT1, mostram duas bandas fortes, corroborando a suspeita de que na verdade sejam dois polipeptídeos maiores, como ocorre em C. elegans. 


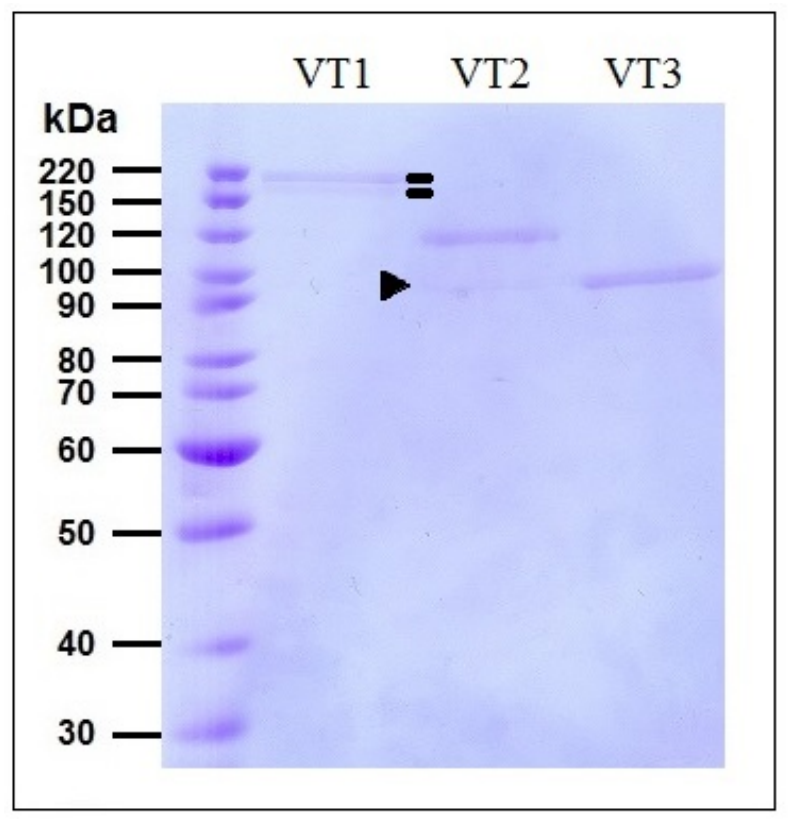

Figura 4.6: SDS-PAGE dos polipeptídeos de VTG separados por eletroeluição. As duas linhas escuras mostram as duas bandas observadas na amostra que se acreditava ser VT1. Talvez estas bandas sejam homólogas aos polipeptídeos YP170A e YP170B de C. elegans. A seta escura mostra uma contaminação de VT3 na amostra de VT2. As bandas foram coradas com Comassie Blue $(\mathrm{T}=10 \%)$.

\subsection{Caracterização dos genes de VTG}

\subsubsection{RNAseq}

H. baujardi LPP7 não possui, até o momento, nenhum gene estrutural sequenciado. Desta forma, para caracterizar os genes que codificam a vitelogenina neste nematoide, usamos como primeira estratégia um ensaio de sequenciamento de RNA mensageiro. Para isso, fizemos a extração de RNA total de fêmeas maduras, com muitos ovos em formação. A partir do RNA total, foi feita a purificação do mRNA através de um kit para purificação de mRNA de tecido (ver item 3.3.2). O sequenciamento foi realizado pela plataforma SOLID, que utiliza octâmeros marcados com fluoróforos para identificar a sequência alvo. As 5 primeiras bases são as que ligarão na sequência de RNA utilizada como template. As outras 3 bases têm sua extremidade ligada ao fluoróforo e se ligam de forma inespecífica ao template, ligação esta que libera o fluoróforo e permite a leitura de cor para interpretação da sequência do template.

A análise dos dados foi realizada pelo colaborador deste projeto, Prof. Dr. Arthur Gruber. O sequenciamento disponibilizou cerca de 42 milhões de leituras (reads), dos quais apenas 14 milhões eram utilizáveis após trimagem e filtragem, devido à baixa qualidade da sequência em escala de pontuação (Figura B.1 - Apêndice). A partir destes 14 milhões de reads, foram 
$\mathbf{A}$

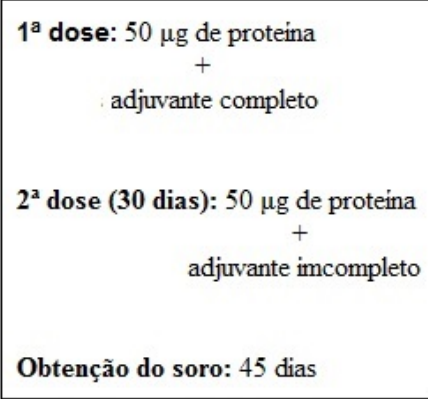

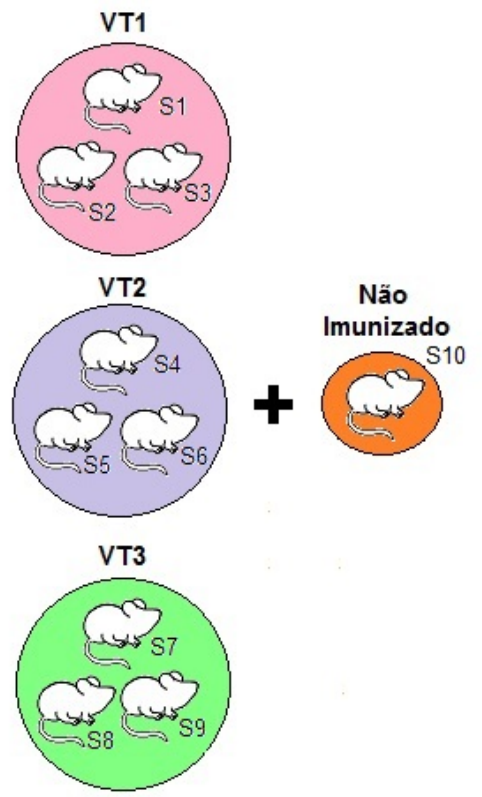

B

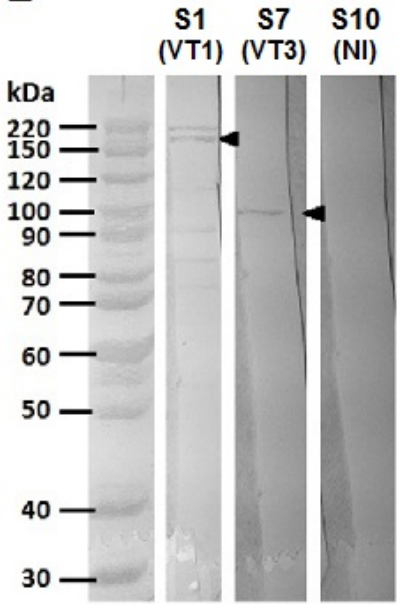

Figura 4.7: Produção de antissoros monoespecíficos. (A) Esquema ilustrativo dos procedimentos de produção dos anticorpos monoespecíficos. (B) Membranas de Western-blot reveladas com 4-cloro-naftol para a atividade da peroxidase. Quase todos os antissoros apresentaram um título muito baixo, além de reconhecerem peptídeos inespecíficos. Não estão mostradas as membranas de todos os soros, apenas um exemplo do grupo imunizado com VT1 (soro 1) e um do grupo imunizado com VT3 (soro 7). Os soros dos camundongos do grupo de VT2 não apresentaram reconhecimento contra bandas de vitelogenina (dados não mostrados). $O$ único antissoro com resultado satisfatório foi o de número 7 (antissoro anti-VT3), com uma única banda forte. Os soros anti-VT1 reconheceram duas bandas fortes, o que corrobora com a hipótese de que o VT1 na verdade sejam dois polipeptídeos de mesmo tamanho. $O$ soro do camundongo não imunizado não reconheceu nenhuma proteína, sendo um controle satisfatório.

construídos 19 contigs, utilizando o programa Abyss (BIROL et al., 2009; ROBERTSON et al., 2010; SIMPSON et al., 2009). Um banco de dados foi criado para depósito destes 19 contigs e eles foram então comparados com banco de dados das vitelogeninas de O. tipulae, à procura de sequências dos genes homólogos de LPP7. Após fazer o tBLASTn entre os dois bancos, chegamos à conclusão de que 11 destes 19 contigs pertencem ao gene vit- 6 de H. baujardi (Hba-vit-6). A Figura 4.8 mostra o mapeamento dos 11 contigs ao longo da proteína OTI-VIT-6.

\begin{tabular}{|c|c|c|c|c|c|c|}
\hline & S09 & 500aa & & $1500 \mathrm{a}$ & & $\begin{array}{l}\mathrm{S} 16 \\
\mathrm{E}\end{array}$ \\
\hline \multicolumn{7}{|c|}{ OTI-VIT-6 } \\
\hline S07 S08 & $\mathrm{s}$ & & $\mathrm{s} 11 \quad \mathrm{~s} 12$ & s13 & S14 S15 & s17 \\
\hline
\end{tabular}

Figura 4.8: Mapeamento dos contigs de RNAseq ao longo da proteína VIT-6 de O. tipulae. 


\subsubsection{Produção de oligonucleotideos a partir do RNAseq}

Como estratégia secundária diante dos resultados do sequenciamento de mRNA, foram construídos oligonucleotídeos a partir dos 11 contigs alinhados com a proteína OTI-VIT-6 e provavelmente pertencentes ao gene Hba-vit-6 (ver item 3.3.3 e Tabela 3.1). O objetivo seria construir pares de oligonucleotídeos que permitissem que "fechássemos" a sequência deste gene, de aproximadamente $5 \mathrm{~Kb}$, resultado este que não foi possível com o RNAseq.

\subsubsection{Alinhamento entre H. bacteriophora $e$ O. tipulae e produção de oligonucleotideos degenerados}

Além da estratégia do RNAseq, foi realizado um alinhamento entre duas espécies filogeneticamente muito próxima de H. baujardi LPP7, O. tipulae e H. bacteriophora. Os genes vit- 6 destas duas espécies, obtidos por nosso laboratório ou disponíveis no projeto de ESTs (GenBank) de H. bacteriophora, foram alinhados através do programa Clustalw. O objetivo foi construir oligos degenerados nas regiões mais conservadas deste alinhamento, a fim de amplificar fragmentos do gene vit-6 de H. baujardi LPP7 e possibilitar sua caracterização.

\subsubsection{RT-PCR para amplificar o gene Hba-vit-6}

A partir dos oligonucleotídeos construídos com as duas estratégias anteriores, foram feitos ensaios de PCR com cDNA. A dupla fita foi feita a partir do mesmo template de RNA total que foi enviado ao sequenciamento de mRNA. De todos os pares de oligonucleotídeos testados, os que amplificaram os fragmentos esperados estão listados na Tabela 3.2 (ver item 3.3.5). A Figura 4.9 mostra os fragmentos amplificados analisados em gel de agarose 1\%, bem como a posição dos fragmentos ao longo da proteína OTI-VIT-6.

\subsubsection{Clonagem e sequenciamento de fragmentos amplificados}

Foram feitas tentativas de clonagem para todos os fragmentos amplificados (ver item anterior) e purificados. Porém, o único resultado satisfatório foi para o fragmento de letra I, cujo par de oligonucleotídeos foi construído a partir do alinhamento entre espécies filogeneticamente próximas. A clonagem foi realizada em dois tipos de plasmídeo: TOPO e pGEM (ver itens 3.3.7 e 3.3.8). A Figura 4.10 mostra o gel de agarose com as bandas de fragmentos clonados e os vetores utilizados. Pode-se observar que, além da banda de tamanho 


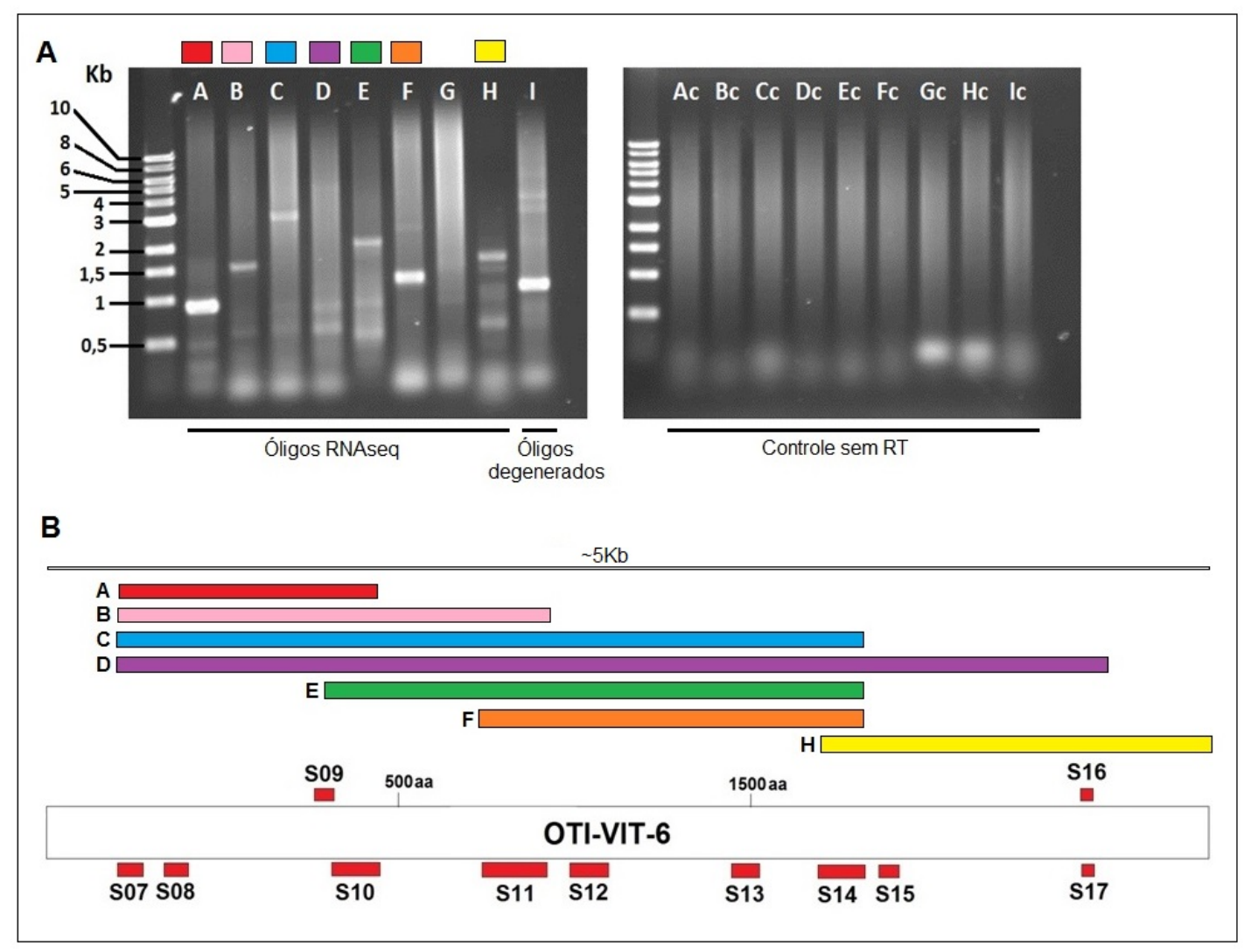

Figura 4.9: RT-PCR para amplificar fragmentos do gene vit-6 de $H$. baijardi LPP7. (A) Gel de agarose $1 \%$ corado com brometo de etídeo. As bandas mostram os fragmentos amplificados dos pares de oligonucleotídeos da Tabela 3.2, na mesma ordem (no gel e na tabela). $O$ único ensaio que não amplificou fragmento foi o de letra $G$ (par de oligonucleotídeos não mostrado). $O$ ensaio de letra I refere-se ao par de óligos provenientes do alinhamento entre espécies próximas, os demais são provenientes do sequenciamento de mRNA. $O$ gel da direita mostra os controles do experimento, sem adição de Transcriptase Reversa, pois caso houvesse contaminação por DNA, as bandas se repetiriam neste gel. (B) Mapeamento dos fragmentos amplificados a partir de oligonucleotídeos do RNAseq sobre a proteína VIT-6 de $O$. tipulae.

esperado, correspondente à vitelogenina $(1,3 \mathrm{~Kb})$, outro fragmento foi clonado, de tamanho menor. Os dois fragmentos clonados em TOPO foram sequenciados e mostramos que o fragmento de tamanho esperado realmente era um fragmento do gene vit- 6 de $H$. baujardi. $\mathrm{O}$ fragmento menor correspondia a um gene que codifica a proteína ribossômica L8. Os sequenciamentos foram realizados baseados no método de sequenciamento enzimático por didesoxinucleotídeos (SANGER et al., 1977).

\subsubsection{Caracterização do fragmento do gene vit-6 de H. baujardi $L P P 7$}

O fragmento do gene vit- 6 sequenciado foi traduzido na terceira fase de leitura e alinhado com sequências de bancos de dados públicos. Trata-se do gene codificante da região N-terminal da proteína VIT-6 de H. baujardi LPP7. Este gene codifica o polipeptídeo 


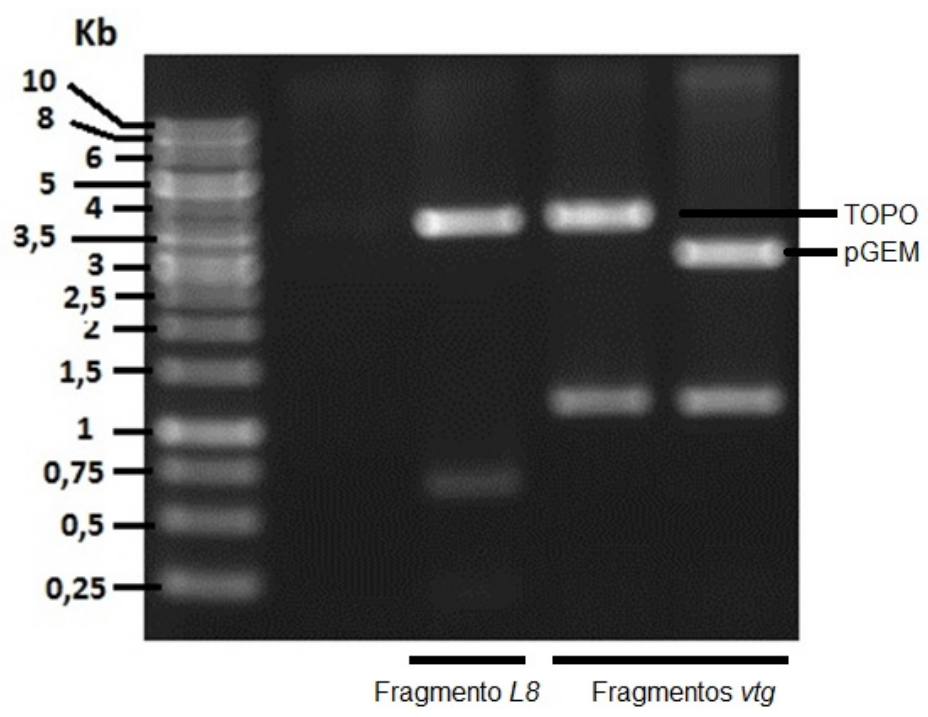

Figura 4.10: Gel de agarose 1\% mostrando os fragmentos codificantes de VTG clonados e TOPO e pGEM e o fragmento codificante da proteína ribossômica L8, clonado em TOPO.

precursor de VT2 e VT3, homólogos dos polipeptídeos de mesmo nome de O. tipulae e dos polipeptídeos YP115 e YP88 de C. elegans. A sequência putativa de aminoácidos contém o sítio de clivagem proteolítica desta proteína. Portanto ela provavelmente contem o lado C-terminal do polipeptídeo VT3 de H. baujardi LPP7. Um alinhamento do fragmento com sequências de espécies filogeneticamente próximas mostrou que o produto da tradução possui $61 \%$ de identidade com OTI-VIT-6, 46\% de identidade com CEL-VIT-6 e $88 \%$ de identidade com HBA-VIT-6 (VIT-6 de Heterorhabditis bacteriophora, um nematoide entomopatogênico do mesmo gênero de LPP7) (Tabela 4.1). Este dado corrobora a hipótese de que LPP7 é mais próximo filogeneticamente de $O$. tipulae do que de $C$. elegans, apesar de não sabermos com certeza se possui o mesmo padrão dos polipeptídeos daquela espécie. A Figura 4.11 mostra o alinhamento entre o produto da tradução da terceira fase de leitura do fragmento clonado (VIT-6 de LPP7) com as sequências das proteínas VIT-6 de O. tipulae (OTI-VIT-6) (NCBI: Q94637), de C.elegans (CEL-VIT-6) (NCBI: NP_001023276.1 -refseq Isoforma C) e Heterorhabditis bacteriophora (HBA-VIT-6) (Wormbase: Hba_21264). Este alinhamento foi realizado através do ClustawX2 (LARKIN et al., 2007).

Tabela 4.1: Porcentagem de identidade entre as sequências alinhadas na Figura 4.11

\begin{tabular}{|l|l|l|l|l|}
\hline & LPP7-VT3 & HBA-VT3 & OTI-VT3 & CEL-YP88 \\
\hline LPP7-VT3 & 100 & & & \\
\hline HBA-VT3 & 88 & 100 & & \\
\hline OTI-VT3 & 61 & 58 & 100 & \\
\hline CEL-YP88 & 46 & 46 & 50 & 100 \\
\hline
\end{tabular}




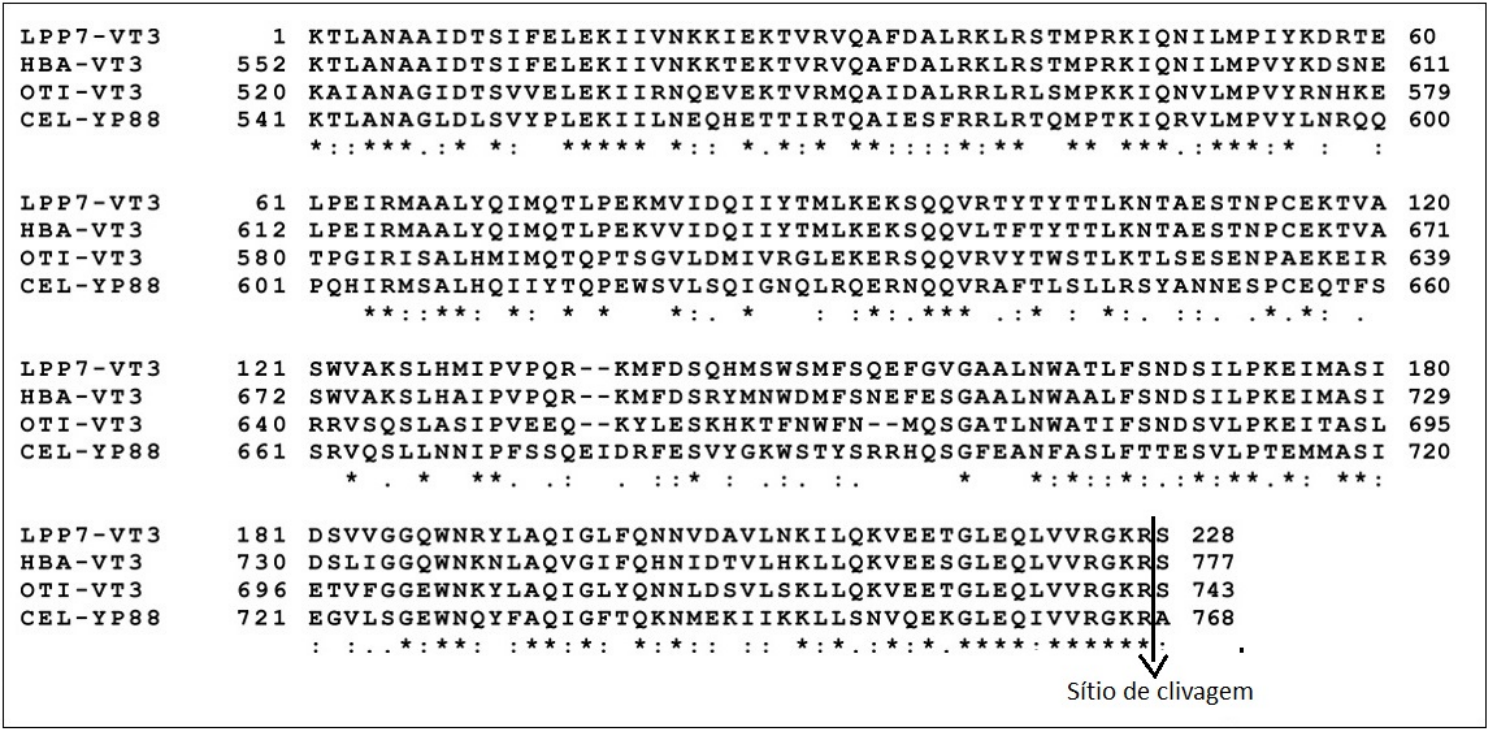

Figura 4.11: Alinhamento entre a sequência traduzida de vit-6 de LPP7 e sequências de VIT-6 de espécies filogeneticamente relacionadas. A seta preta indica a região de clivagem desta proteína, depois do sítio de Lisina-Arginina, pela ação de uma enzima do tipo pró-hormônio convertase. 


\section{DISCUSSÃO}

\subsection{Cultura de Nematoides Entomopatogênicos}

Um dos resultados apresentados nesta dissertação foi a manutenção in vitro do NEP LPP7. Esta técnica foi descrita há décadas e vem sendo aprimorada ao longo do tempo (BEDDING, 1981; GLASER, 1931; HUSSAINI et al., 2002; KAYA; STOCK, 1997). O uso da cultura in vitro foi estabelecido com o objetivo de obter Jis, principalmente para aplicação como controle de artrópodes pragas de plantações. A principal vantagem deste método em relação à criação in vivo é a obtenção de maior número de nematoides em menos tempo, e de forma mais barata.

Apesar de já estar descrita com outros protocolos e objetivos, estabelecemos e adaptamos a cultura in vitro no laboratório durante o desenvolvimento da parte experimental desta dissertação. O desenvolvimento desta técnica foi de grande importância, pois o único estádio do nematoide facilmente obtido são os juvenis infectantes. Todas as outras fases de vida encontram-se dentro do corpo do hospedeiro, o que dificulta e inviabiliza sua obtenção. Como estávamos interessados em estudar as proteínas de vitelo, que são encontradas apenas nos ovos em formação e já formados de fêmeas de $1^{\mathrm{a}}$ ou $2^{\mathrm{a}}$ geração, era necessário obter este estágio em quantidade suficiente. O cultivo em placa permite a obtenção rápida destas fases do ciclo de vida do verme, em quantidade suficiente para os ensaios desenvolvidos neste trabalho. A manutenção desta técnica foi possível porque a bactéria simbionte, Photorhabdus luminescens MN7, foi previamente isolada em nosso laboratório e pode ser cultivada também in vitro. Trata-se de uma bactéria gram negativa da família Enterobacteriaceae, que pode ou não ser bioluminescente (SAUX et al., 1999).

Depois de alguma gerações em placa, o nematoide deixa de ser eficaz na infecção de larvas de inseto, provavelmente pela não formação da forma infectante. Glaser (1931) já havia observado que os nematoides mantidos in vitro perdiam a capacidade de infectar e que era necessário infectar larvas de insetos com certo intervalo de tempo para recuperar os Jis. Nesta época, Glaser cultivava nematoides entomopatogênicos em bandejas com agar e vísceras de animais, e não se conhecia ainda a bactéria simbionte dos entomopatogênicos. No entanto os

motivos para essa perda de infectividade ainda são desconhecidos. É pouco provável que esta situação ocorra por "falhas" na relação entre nematoide e bactéria, já que mesmo depois de algumas gerações em placa, o nematoide ainda não se desenvolve na presença de outra bactéria que não seja a sua simbionte (dados não mostrados).

A simbiose entre nematoide e bactéria é uma relação fascinante do ponto de vista biológico. $\mathrm{O}$ nematoide depende da bactéria para infectar e matar seu hospedeiro, ao mesmo tempo que 
se alimenta dela. A bactéria depende do nematoide para dispersão de um hospedeiro para outro, mas mata sozinha o inseto em um ou dois dias. Além disso, a especificidade desta relação é extremamente restrita, sendo que cada espécie de nematoide tem uma única linhagem específica da bactéria simbionte em se intestino (HUSSA; GOODRICH-BLAIR, 2013). Muitas informações sobre essa relação ainda estão para serem descobertas e alguns fatos continuam sendo um mistério para os cientistas.

Esta especificidade na simbiose também ocorre com a linhagem de $H$. baujardi utilizada neste trabalho. Os nematoides foram incubados em placas contendo outras linhagens de bactérias gram negativas (E. coli e P. luminescens MN12). Observou-se que os nematoides não se desenvolviam nestas situações e chegavam a morrer. Mesmo a bactéria da linhagem MN12, pertencente à mesma espécie da bactéria simbionte (MN7), mas oriunda de outra espécie de Heterorhabditis (H. indica), não se mostrou eficaz no teste da simbiose. É curioso que na situação do ciclo de vida in vitro, o nematoide mantenha os comportamentos naturais e a simbiose se mantenha tão específica.

\subsection{Genes de Vitelogenina de Nematoides}

Neste trabalho foi realizada a clonagem e sequenciamento de um fragmento pequeno do gene vit-6 de $H$. baujardi LPP7 (cerca de $809 \mathrm{pb}$ ). Isso compreende pouco menos de um quinto do gene completo. A sequência completa e sua caracterização foi um dos objetivos centrais deste projeto, no entanto os ensaios realizados não foram suficientes para sua obtenção.

O gene vit-6 codifica o precursor dos polipeptídeos VT2 e VT3 de O. tipulae (ou YP115 e YP88 de C. elegans), que é proteoliticamente clivado no pseudoceloma antes da tomada via receptores nos ovócitos. A sequência obtida da linhagem LPP7 possui um domínio N-terminal de lipoproteínas, indicando que se trata da porção do gene que codifica o lado C-terminal do polipeptídeo homólogo a VT3 (ou a YP88). A análise por alinhamento em CLUSTAL W 2.0 (LARKIN et al., 2007) da sequência obtida e das regiões homólogas, mostrou que o a sequência putativa de aminoácidos possui $61 \%$ de identidade com VIT-6 de O. tipulae CEW1 e 46\% de identidade com VIT-6 de C. elegans. Este dado corrobora a proximidade filogenética entre Heterorhabditis e Oscheius (Figura 5.2). Além disso, possui 88\% de identidade com a sequência de VIT-6 de H. bacteriophora, um nematoide pertencente ao mesmo gênero de LPP7, o que explica a similaridade tão grande.

Comparando-se a região do sítio de clivagem de VIT-6, percebe-se que a região de processamento proteolítico (RGKR-P4 a P1) está presente nos precursores VIT-6 das quatro espécies analisadas. No entanto, notam-se diferenças na região flanqueadora deste sítio. Como 
descrito anteriormente, acredita-se que se trata de um sítio reconhecido por uma enzima do tipo pró-hormônio convertase que cliva a proteína depois do resíduo Lisina-Arginina (ANDREONI-NICO, 2008; WINTER et al., 1996). Em C. elegans, o sítio P1' (uma posição depois do sítio de clivagem) é ocupado por um resíduo de alanina (Figura 5.1), que é conservado na maioria dos Caernohabditis (dados não mostrados). Já em H. bacteriophora, O. tipulae e como agora sabemos, em LPP7, este sítio é ocupado por um resíduo de serina. Isso também reafirma a hipótese de maior proximidade filogenética entre LPP7 e $O$. tipulae.

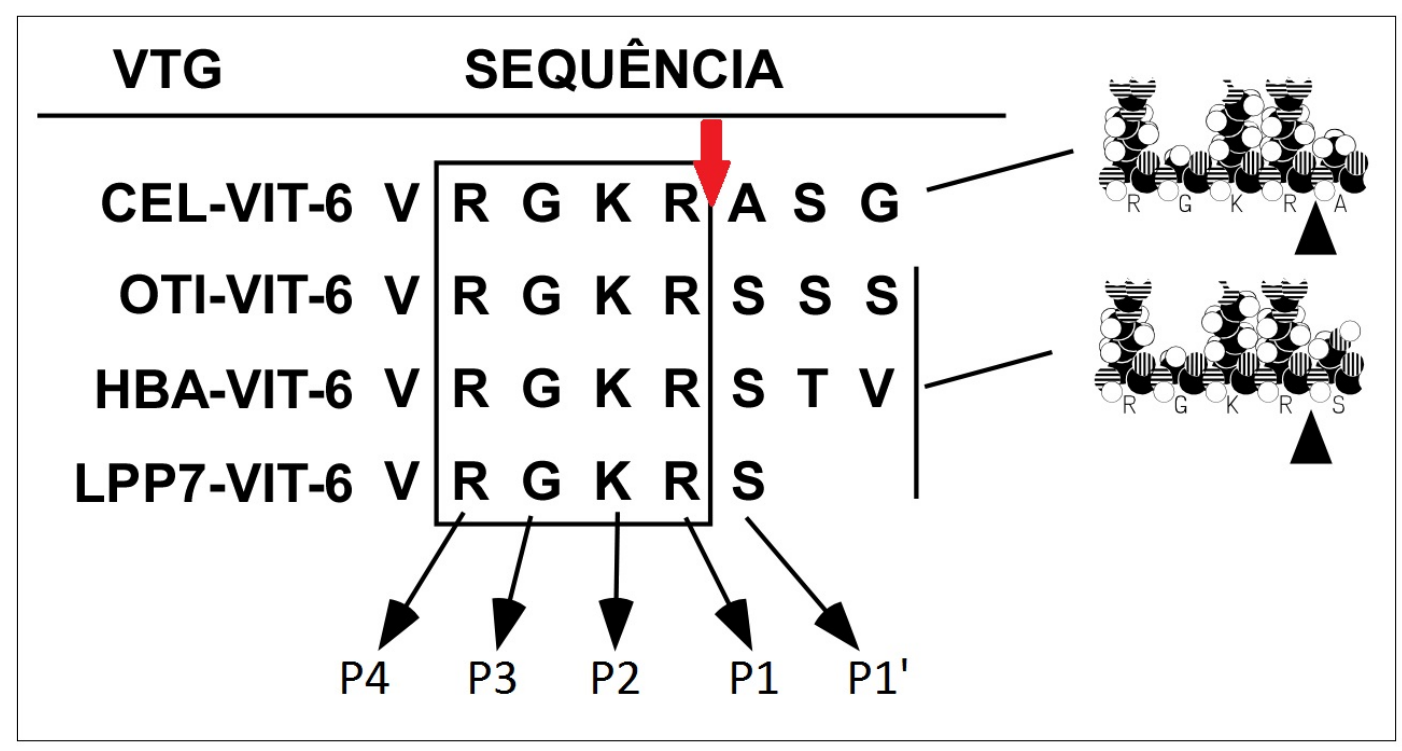

Figura 5.1: Sítios de clivagem do precursor VIT-6 em diferentes espécies de rhabditídeos. Foram alinhados os sítios de reconhecimento da enzima pró hormônio convertase de VIT-6 das quatro espécies analisadas: $C$. elegans, $O$. tipulae, $H$. bacteriophora e $H$. baujardi LPP7 (na ordem de cima para baixo). A seta vermelha indica o local da clivagem. Do lado direito estão as estruturas das proteínas, bem como os sítios de clivagem com resíduo de alanina e serina (setas escuras). Figura extraída e adaptada de Andreoni-Nico (2008).

\subsection{Vitelinas de Nematoides}

Os resultados apresentados nesta dissertação mostram que o padrão dos polipeptídeos de vitelo do nematoide entomopatogênico Heterorhabditis baujardi linhagem LPP7 se assemelha ao padrão encontrado em outros nematoides próximos filogeneticamente. Há inúmeros estudos dedicados ao entendimento da vitelogênese em $C$. elegans, processo cuja biologia celular foi bem estudada neste nematoide (BLUMENTHAL et al., 1984; GRANT; HIRSH, 1999; HEINE; BLUMENTHAL, 1986; SHARROCK, 1983; SHARROCK et al., 1990). Além disso, outro nematoide de vida livre, O. tipulae também foi alvo deste tipo de estudo (ALMENARA et al., 2013; WINTER et al., 1996; WINTER, 2002). Sabe-se que C. elegans e O. tipulae CEW1 possuem diferenças marcantes no padrão de vitelinas, além de diferenças no processo 
de vitelogênese. O primeiro apresenta um padrão de quatro polipeptídeos de vitelo (YP170A, YP170B, YP115 e YP88), enquanto o segundo apresenta apenas três polipeptídeos (VT1, VT2 e VT3), sendo que VT2 e VT3 são homólogos dos polipeptídeos YP115 e YP88, respectivamente. Acreditávamos que o nematoide estudado neste trabalho apresentava o mesmo padrão encontrado em O. tipulae, por apresentar três bandas bem nítidas de vitelogenina. Isso apoiaria a hipótese da proximidade filogenética entre estas duas espécies (Figura 5.2).

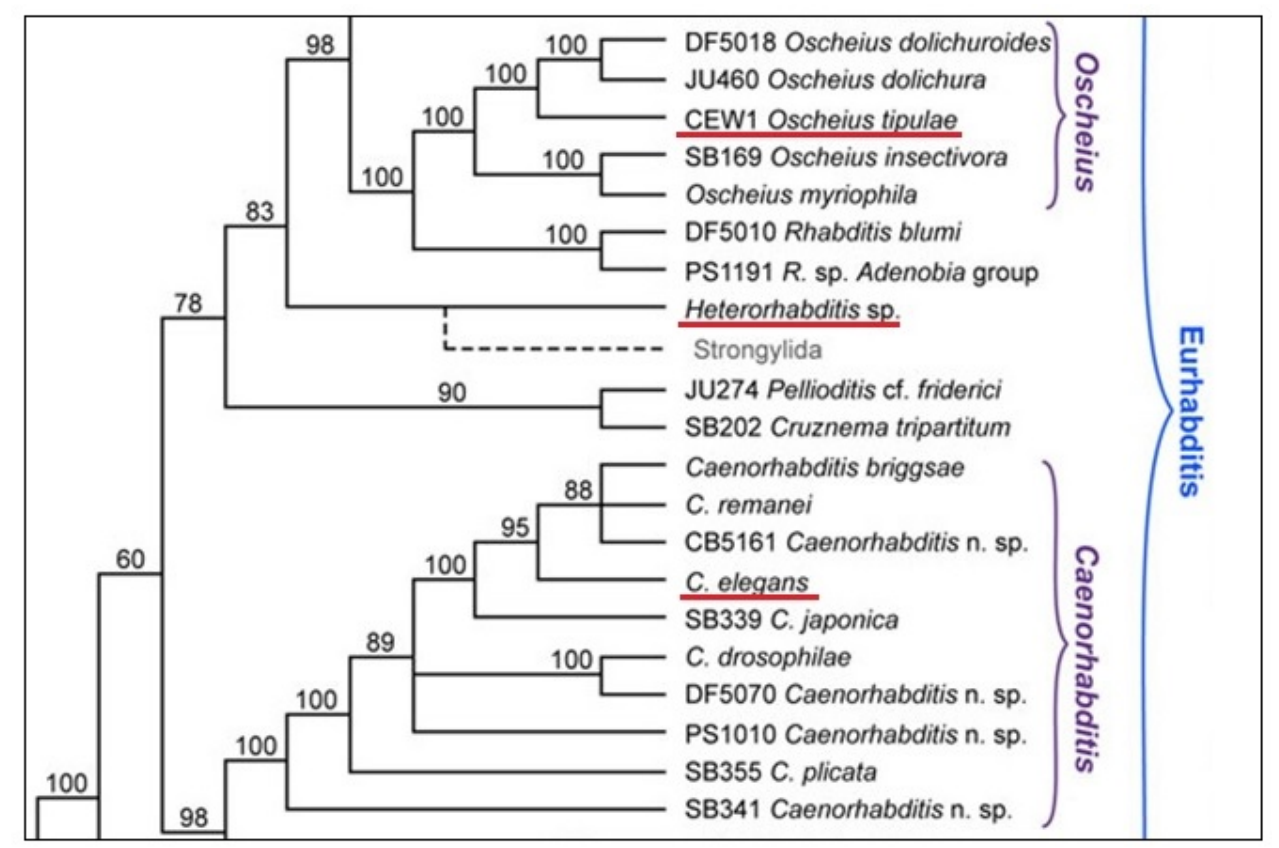

Figura 5.2: Relação filogenética dos nematoides Rhabditídeos. Em destaque, as três espécies de nematoides comparadas, sendo que $H$. baujardi LPP7 é representada pelo gênero Heterorhabditis. Figura extraída e modificada de Wormbook (Acesso em: 2014)

Porém, em géis preparativos onde a quantidade de amostra aplicada foi menor e o tempo da eletroforese foi maior, pudemos observar a presença de duas bandas na altura do polipeptídeo que seria VT1. Estas bandas podem indicar a presença de dois polipeptídeos homólogos a YP170A e YP170B. Havia a mesma suspeita durante os estudos de vitelogeninas de CEW1, porém foi mostrado que a proteína da banda maior apresenta uma única sequência $\mathrm{N}$-terminal quando sequenciado pelo método de Edman, indicando que se tratavam de um único polipeptídeo (ALMENARA et al., 2013; WINTER et al., 1996; WINTER, 2002).

Podemos propor, para estes dados, que o gênero Oscheius seja a a raiz da árvore filogenética que une Heterorhabditis e Caernohabditis, e que a duplicação do gene que codifica VT1/YP170 tenha ocorrido antes do surgimento dos outros dois gêneros. Uma outra hipótese é que a duplicação seja ancestral a todos eles e um dos genes tenha sido perdido em Oscheius. Uma vez que duplicações são mais frequentes a primeira hipótese é mais plausível. É difícil afirmar 
que os polipeptídeos de LPP7 seguem um padrão ou outro sem maiores estudos, mas é provável que existam 4 polipeptídeos, dois deles com mesmo peso molecular e indistinguíveis em alguns ensaios de SDS-PAGE, quando quantidades maiores de proteína são aplicadas ao gel.

Adicionalmente, ensaios de imunofluorescência foram tentados com o anticorpo anti-VT3 produzido durante este trabalho. Porém, este não possuía título suficiente para obter resultados dignos (dados não mostrados). 


\section{REFERÊNCIAS $^{9}$}

ALMENARA, D. P.; MOURA, J. P. de; SCARABOTTO, C. P.; ZINGALI, R. B.; WINTER, C. E. The molecular and structural characterization of two vitellogenins from the free-living nematode Oscheius tipulae. PLoS ONE, Public Library of Science, v. 8, n. 1, p. e53460, 2013.

ALMENARA, D. P.; ROSSI, C.; NEVES, M. R. C.; WINTER, C. E. Nematoides Entomopatogênicos. Tópicos Avançados em Entomologia Molecular. INTC. [S.l.: s.n.], 2012.

ANDREONI-NICO, J. Evidências de redundância funcional entre as pró-hormônio convertases no processamento pós-traducional do precursor da vitelogenina VIT-6 do nematóide Caenorhabditis elegans. Tese (Doutorado) - Tese de doutorado apresentada aoInstituto de Ciências Biomédicas da Universidade de São Paulo, 2008.

BEDDING, R. Low cost in vitro mass production of Neoaplectana and Heterorhabditis species (Nematoda) for field control of insect pests. Nematologica, v. 27, p. 109-114, 1981.

BIROL, I.; JACKMAN, S. D.; NIELSEN, C. B.; QIAN, J. Q.; VARHOL, R.; STAZYK, G.; MORIN, R. D.; ZHAO, Y.; HIRST, M.; SCHEIN, J. E.; HORSMAN, D. E.; CONNORS, J. M.; GASCOYNE, R. D.; MARRA, M. A.; JONES, S. J. M. De novo transcriptome assembly with ABySS. Bioinformatics, v. 25, n. 21, p. 2872-2877, 2009.

BLAXTER, M.; DENVER, D. The worm in the world and the world in the worm. BMC Biology, v. 10, n. 1, p. 57, 2012.

BLAXTER, M.; KOUTSOVOULOS, G. The evolution of parasitism in Nematoda. Parasitology, FirstView, p. 1-14, 2014.

BLAXTER, M.; DE LEY, P.; GAREY, J.; LIU, L.; SCHELDEMAN, P.; VIERSTRAETE, A.; VANFLETEREN, J.; MACKEY, L.; DORRIS, M.; FRISSE, L.; VIDA, J.; THOMAS, W. A molecular evolutionary framework for the phylum Nematoda. Nature, v. 392, n. 6671, p. 71-75, 1998.

BLUMENTHAL, T.; SQUIRE, M.; KIRTLAND, S.; CANE, J.; DONEGAN, M.; SPIETH, J.; SHARROCK, W. Cloning of a yolk protein gene family from Caenorhabditis elegans. Journal of Molecular Biology, v. 174, n. 1, p. 1 - 18, 1984.

BOEMARE, N. E.; AKHURST, R. J.; MOURANT, R. G. DNA Relatedness between Xenorhabdus spp. (Enterobacteriaceae), symbiotic bacteria of entomopathogenic nematodes, and a proposal to transfer Xenorhabdus luminescens to a new genus, Photorhabdus gen. nov. International Journal of Systematic Bacteriology, v. 43, n. 2, p. 249-255, 1993.

BUISINE, N.; TRICHET, V.; WOLFF, J. Complex evolution of vitellogenin genes in salmonid fishes. Molecular Genetics and Genomics, Springer-Verlag, v. 268, n. 4, p. 535-542, 2002.

BUNDY, D. This wormy world - then and now. Parasitology Today, v. 13, p. p. 407-408, 1997.

\footnotetext{
${ }^{9}$ DE ACORDO COM: ASSOCIAÇÃO BRASILEIRA DE NORMAS TÉCNICAS. NBR 6023: INFORMAÇÃO E DOCUMENTAÇÃO: REFERÊNNCIAS: ELABORAÇÃO. RIO DE JANEIRO, 2002.
} 
BYRNE, B.; GRUBER, M.; AB, G. The evolution of egg yolk proteins. Progress in Biophysics and Molecular Biology, v. 53, n. 1, p. 33 - 69, 1989.

CHEN, J.-S.; SAPPINGTON, T. W.; RAIKHEL, A. S. Extensive sequence conservation among insect, nematode, and vertebrate vitellogenins reveals ancient common ancestry. Journal of Molecular Evolution, Springer-Verlag, v. 44, n. 4, p. 440-451, 1997.

CHIRGWIN, J. M.; PRZYBYLA, A. E.; MACDONALD, R. J.; RUTTER, W. J. Isolation of biologically active ribonucleic acid from sources enriched in ribonuclease. Biochemistry, v. 18, n. 24, p. 5294-5299, 1979.

DHADIALLA, T. S.; RAIKHEL, A. S. Biosynthesis of mosquito vitellogenin. Journal of Biological Chemistry, v. 265, n. 17, p. 9924-9933, 1990.

DOLINSKI, C.; KAMITANI, F. L.; MACHADO, I. R.; WINTER, C. E. Molecular and morphological characterization of heterorhabditid entomopathogenic nematodes from the tropical rainforest in Brazil. Memórias do Instituto Oswaldo Cruz, SciELO Brasil, v. 103, n. 2, p. 150-159, 2008.

DOLINSKI, C.; VALLE, E. D.; STUART, R. J. Virulence of entomopathogenic nematodes to larvae of the guava weevil, Conotrachelus psidii (coleoptera: Curculionidae), in laboratory and greenhouse experiments. Biological Control, v. 38, n. 3, p. 422 - 427, 2006.

ELEFTHERIANOS, I.; R H FFRENCH-CONSTANT, R. H.; CLARKE, D. J.; DOWLING, A. J.; REYNOLDS, S. E. Dissecting the immune response to the entomopathogen Photorhabdus. Trends in Microbiology, v. 18, n. 12, p. 552-560, 2010.

FÉLIX, M.-A. Oscheius tipulae. WormBook, ed. The C. elegans Research Community, WormBook, 2006.

GARCIA, L. C.; RAETANO, C. G.; LEITE, L. G. Application technology for the entomopathogenic nematodes Heterorhabditis indica and Steinernema sp. (Rhabditida: Heterorhabditidae and Steinernematidae) to control Spodoptera frugiperda (smith) (lepidoptera: Noctuidae) in corn. Neotropical Entomology, scielo, v. 37, p. 305 - 311, 2008.

GAUGLER, R. Ecological considerations in the biological control of soilinhabiting insects pests with entomopathogenic nematodes. Agr. Ecosyst. Environ, p. 24, 351-360, 1988.

GAUGLER, R. Entomopathogenic nematology. CABI Publishing, 2002.

GLASER, R. W. The cultivation of a nematode parasite of an insect. Science, v. 73, n. 1901, p. 614-615, 1931.

GRANT, B.; HIRSH, D. Receptor-mediated endocytosis in the Caenorhabditis elegans oocyte. Molecular Biology of the Cell, v. 10, n. 12, p. 4311-4326, 1999.

GUBANOV. Giant nematode from the placenta of cetaceans - Placentonema gigantissima nov.gen. nov.sp. Doklady Akademii Nayuk SSSR, v. 77, p. p. 1123-1125 (in Russian), 1951.

HEINE, U.; BLUMENTHAL, T. Characterization of regions of the Caenorhabditis elegans $\mathrm{x}$ chromosome containing vitellogenin genes. Journal of molecular biology, v. 188, n. 3, p. $301-312,1986$. 
HOTEZ, P.; OTTESEN, E.; FENWICK, A.; MOLYNEUX, D. The neglected tropical diseases: the ancient afflictions of stigma and poverty and the prospects for their control and elimination. Advances in Experimental Medicine and Biology, v. 582, p. p. 23-33, 2006.

HUSSA, E. A.; GOODRICH-BLAIR, H. It takes a village: Ecological and fitness impacts of multipartite mutualism. Annual Review of Microbiology, v. 67, n. 1, p. 161-178, 2013.

HUSSAINI, S.; SINGH, S.; NAGESH, M. In vitro and field evaluation of some indigenous isolates os Steinernema and Heterorhabditis indica against shoot and fruit borer, Leucinodes orbonalis. Indian Journal of Nematology, v. 32, p. 63-65, 2002.

KAYA, H. K.; STOCK, P. Chapter vi - techniques in insect nematology. In: LACEY, L. A. (Ed.). Manual of Techniques in Insect Pathology. London: Academic Press, 1997. p. 281 324.

LAMBSHEAD, P. Recent developments in marine benthic biodiversity research. Oceanis, v. 19, p. p. 5-24, 1993.

LARKIN, M.; BLACKSHIELDS, G.; BROWN, N.; CHENNA, R.; MCGETTIGAN, P.; MCWILLIAM, H.; VALENTIN, F.; WALLACE, I.; WILM, A.; LOPEZ, R.; THOMPSON, J.; GIBSON, T.; HIGGINS, D. Clustal W and Clustal X version 2.0. Bioinformatics, v. 23, n. 21, p. 2947-2948, 2007.

DE LEY, P. A quick tour of nematode diversity and the backbone of nematode phylogeny. WormBook, p. p. 1-8, 2006.

LIM, E. H.; TEO, B. Y.; LAM, T. J.; DING, J. L. Sequence analysis of a fish vitellogenin cdna with a large phosvitin domain. Gene, v. 277, n. 1-2, p. 175 - 186, 2001.

LORDELLO, L. G. E. Endotoquia matricida. em Rbabditis sp. (Nematoda, Rbabditidae). An. E. S. A. 'Luiz de Queiroz', p. 8: 111-114, 1951.

MANN, C. J.; ANDERSON, T. A.; READ, J.; CHESTER, S.; HARRISON, G. B.; KöCHL, S.; RITCHIE, P. J.; BRADBURY, P.; HUSSAIN, F. S.; AMEY, J.; VANLOO, B.; ROSSENEU, M.; INFANTE, R.; HANCOCK, J. M.; LEVITT, D. G.; BANASZAK, L. J.; SCOTT, J.; SHOULDERS, C. C. The structure of vitellogenin provides a molecular model for the assembly and secretion of atherogenic lipoproteins. Journal of Molecular Biology, v. 285, n. 1, p. $391-408,1999$.

MATYASH, V.; ENTCHEV, E. V.; MENDE, F.; WILSCH-BRÄUNINGER, M.; THIELE, C.; SCHMIDT, A. W.; KNöLKER, H.-J.; WARD, S.; KURZCHALIA, T. V. Sterol-derived hormone(s) controls entry into diapause in Caenorhabditis elegans by consecutive activation of daf-12 and daf-16. PLoS Biol, Public Library of Science, v. 2, n. 10, p. e280, 2004.

MAUPAS, E. La mue et l'enkystement chez les nématodes. Arch. Zool. exper, p. gén. 7:562$668,1899$.

MCGHEE, J. D.; FUKUSHIGE, T.; KRAUSE, M. W.; MINNEMA, S. E.; GOSZCZYNSKI, B.; GAUDET, J.; KOHARA, Y.; BOSSINGER, O.; ZHAO, Y.; KHATTRA, J.; HIRST, M.; JONES, S. J.; MARRA, M. A.; RUZANOV, P.; WARNER, A.; ZAPF, R.; MOERMAN, D. G.; KALB, J. M. Elt-2 is the predominant transcription factor controlling differentiation and function of the C. elegans intestine, from embryo to adult. Developmental Biology, v. 327, n. 2 , p. $551-565,2009$. 
MEGEN, H. van; ELSEN, S. van den; HOLTERMAN, M.; KARSSEN, G.; MOOYMAN, P.; BONGERS, T.; HOLOVACHOV, O.; BAKKER, J.; HELDER, J. A phylogenetic tree of nematodes based on about 1200 full-length small subunit ribosomal DNA sequences. Nematology, v. 11, p. 927-950, 2009.

OLIVEIRA MONTEIRO, C. M. de; AZEVEDO PRATA, M. C. de; FAZA, A.; PAULA BATISTA, E. S. de; DOLINSKI, C.; FURLONG, J. Heterorhabditis bacteriophora (Rhabditida: Heterorhabditidae) \{HP88\} for biological control of Rhipicephalus microplus (Acari: Ixodidae): The effect of different exposure times of engorged females to the nematodes. Veterinary Parasitology, v. 185, n. 2-4, p. $364-367,2012$.

MOURA, J. P. Análise da região N-terminal da proteína codificada no gene Oti-vit-6 do nematóide Oscheius tipulae e sua interação com um polipeptídeo de 106 kDa. Tese (Doutorado) - Tese de Doutorado apresentada ao Instituto de Ciências Biomédicas da Universidade de São Paulo, 2004.

NOGUEZ, J. H.; CONNER, E. S.; ZHOU, Y.; CICHE, T. A.; RAGAINS, J. R.; BUTCHER, R. A. A novel ascaroside controls the parasitic life cycle of the entomopathogenic nematode Heterorhabditis bacteriophora. ACS Chemical Biology, v. 7, n. 6, p. 961-966, 2012.

ORKIN, S. H. GATA-binding transcription factors in hematopoietic cells. Blood, v. 80, n. 3, p. 575-581, 1992.

PENHA-SCARABOTTO, C. Análise molecular dos polipeptídeos codificados no gene CEW1-vit-6 do nematóide Oscheius n.sp. Tese (Doutorado) - Tese de doutorado apresentada ao Instituto de Ciências Biomédicas da Universidade de São Paulo, 1999.

POINAR, G. O. J. Description and biology of a new insect parasitic rhabditoid, Heterorhabditis bacteriophora n. sp. (Rhabditida: Heterorhabditidae n. fam.). Nematologica, v. 21, p. 463-470, 1976.

ROBERTSON, G.; SCHEIN, J.; CHIU, R.; CORBETT, R.; FIELD, M.; JACKMAN, S. D.; MUNGALL, K.; LEE, S.; OKADA, H. M.; QIAN, J. Q.; GRIFFITH, M.; RAYMOND, A.; THIESSEN, N.; CEZARD, T.; BUTTERFIELD, Y. S.; NEWSOME, R.; CHAN, S. K.; SHE, R.; VARHOL, R.; KAMOH, B.; PRABHU, A.-L.; TAM, A.; ZHAO, Y.; MOORE, R. A.; HIRST, M. De novo assembly and analysis of RNA-seq data. Nature Methods, 2010.

SANGER, F.; NICKLEN, S.; COULSON, A. R. DNA sequencing with chain-terminating inhibitors. Proceedings of the National Academy of Sciences, v. 74, n. 12, p. 5463-5467, 1977.

FISCHER-LE SAUX, M.; VIALLARD, V.; BRUNEL, B.; NORMAND, P.; BOEMARE, N. E. Polyphasic classification of the genus Photorhabdus and proposal of new taxa: P. luminescens subsp. luminescens subsp. nov., P. luminescens subsp. akhurstii subsp. nov., P. luminescens subsp. laumondii subsp. nov., P. temperata sp. nov., P. temperata subsp. temperata subsp. nov. and $P$. asymbiotica sp. nov. International Journal of Systematic and Evolutionary Microbiology, v. 49, n. 4, p. 1645-1656, 1999.

SCHÄGGER, H.; VON JAGOW, G. Tricine-sodium dodecyl sulfate-polyacrylamide gel electrophoresis for the separation of proteins in the range from 1 to $100 \mathrm{kDa}$. Analytical Biochemistry, v. 166, n. 2, p. 368 - 379, 1987. 
SCHNEIDER, W. J. Vitellogenin receptors: Oocyte-specific members of the low-density lipoprotein receptor supergene family. In: JEON, K. W. (Ed.). [S.1.]: Academic Press, 1996, (International Review of Cytology, v. 166). p. 103 - 137.

SHARROCK, W. J. Yolk proteins of Caenorhabditis elegans. Developmental Biology, v. 96, n. 1 , p. $182-188,1983$.

SHARROCK, W. J.; SUTHERLIN, M. E.; LESKE, K.; CHENG, T. K.; KIM, T. Y. Two distinct yolk lipoprotein complexes from Caenorhabditis elegans. Journal of Biological Chemistry, v. 265, n. 24, p. 14422-14431, 1990.

SHEN, M.; HODGKIN, J. mab-3, a gene required for sex-specifc yolk protein expression and a male-specific lineage in C. elegans. Cell, v. 54, p. p. 1019-1031, 1988.

SHUMAN, S. Novel approach to molecular cloning and polynucleotide synthesis using vaccinia DNA topoisomerase. Journal of Biological Chemistry, v. 269, n. 51, p. 32678-32684, 1994.

SIMPSON, J. T.; WONG, K.; JACKMAN, S. D.; SCHEIN, J. E.; JONES, S. J.; BIROL, I. ABySS: A parallel assembler for short read sequence data. Genome Research, v. 19, n. 6, p. 1117-1123, 2009.

SOMVANSHI, V. S.; KAUFMANN-DASZCZUK, B.; KIM, K.-s.; MALLON, S.; CICHE, T. A. Photorhabdus phase variants express a novel fimbrial locus, mad, essential for symbiosis. Molecular Microbiology, Blackwell Publishing Ltd, v. 77, n. 4, p. 1021-1038, 2010.

SPIETH, J.; DENISON, K.; ZUCKER, E.; BLUMENTHAL, T. The nucleotide sequence of anematode vitellogenin gene. Nucleic Acids Research, v. 13, p. p. 7129-7138, 1985.

SPIETH, J.; MACMORRIS, M.; BROVERMAN, S.; GREENSPOON, S.; BLUMENTHAL, T. Regulated expression of a vitellogenin fusion gene in transgenic nematodes. Developmental Biology, v. 130, n. 1, p. 285 - 293, 1988.

STOCK, S. P.; CAMPBELL, J. F.; NADLER, S. A. Phylogeny of Steinernema travassos, 1927 (cephalobina: Steinernematidae) inferred from ribosomal DNA sequences and morphological characters. Journal of Parasitology, v. 87, n. n. 4, p. p. 877-889, 2001.

TELFER, W. H. Immunological studies of insect metamorphosis: Ii. the role of a sex-limited blood protein in egg formation by the Cecroia silkworm. The Journal of General Physiology, v. 37, n. 4 , p. 539-558, 1954.

DEL VALLE, E.; C., D.; E.L.S., B.; R.M., S.; R.I., S. Efficacy of Heterorhabditis baujardi LPP7 (nematoda: Rhabditida) applied in Galleria mellonella (lepidoptera: Pyralidae) insect cadavers to Conotrachelus psidii (coleoptera: Curculionidae) larvae. Bio. Sci. Tech., v. 18, p. 33-41, 2008b.

DEL VALLE, E. E.; DOLINSKI, C.; SOUZA, R. M. Dispersal of Heterorhabditis baujardi LPP7 (nematoda: Rhabditida) applied to the soil as infected host cadavers. International Journal of Pest Management, v. 54, n. 2, p. 115-122, 2008a. 
OLIVEIRA VASCONCELOS, V. de; FURLONG, J.; FREITAS, G. Marques de; DOLINSKI, C.; MENDONçA AGUILLERA, M.; DEVITTE RODRIGUES, R.; PRATA, M. Steinernema glaseri Santa Rosa strain (rhabditida: Steinernematidae) and Heterorhabditis bacteriophora CCA strain (rhabditida: Heterorhabditidae) as biological control agents of Boophilus microplus (acari: Ixodidae). Parasitology Research, Springer-Verlag, v. 94, n. 3, p. 201-206, 2004.

WAHLI, W. Evolution and expression of vitellogenin genes. Trends in Genetics, v. 4, p. p. 227-232, 1988.

WALLACE, R. Vitellogenesis and oocyte growth in nonmammalian vertebrates. In:

BROWDER, L. (Ed.). Oogenesis. [S.1.]: Springer US, 1985, (Developmental Biology, v. 1). p. $127-177$.

WANG, H.; YAN, T.; TAN, J. T.; GONG, Z. A zebrafish vitellogenin gene (vg3) encodes a novel vitellogenin without a phosvitin domain and may represent a primitive vertebrate vitellogenin gene. Gene, v. 256, n. 1-2, p. 303 - 310, 2000.

WATERFIELD, N. R.; CICHE, T.; CLARKE, D. Photorhabdus and a host of hosts. Annual Review of Microbiology, v. 63, n. 1, p. 557-574, 2009.

WHITE, G. F. A method for obtaining infective nematode larvae from cultures. Science, v. 66, n. 1709, p. 302-303, 1927.

WINTER, C. E. The yolk polypeptides of a free-living rhabditid nematode. Comparative Biochemistry and Physiology Part B: Comparative Biochemistry, v. 103, n. 1, p. 189 196, 1992.

WINTER, C. E. Yolk proteins and their precursors in non-arthropod protostomes, with emphasis on nematodes. Reproductive Biology of Invertebrates, p. 1-27, 2002.

WINTER, C. E.; PENHA, C.; BLUMENTHAL, T. Comparison of a vitellogenin gene between two distantly related rhabditid nematode species. Molecular Biology and Evolution, v. 13, n. 5, p. 674-684, 1996.

WOOD, W. Introduction to C. elegans biology. In: WOOD, W.B. The Nematode Caenorhabditis elegans. [S.1.]: New York: Cold Spring Harbor, 1988. p. 243-335 p.

WOODRING, J.; KAYA, H. K. Steinernematidae and Heterorhabditidae nematodes: a handbook of techniques southern cooperative. [S.1.]: Arkansas, Arkansas Agricultural Experiment Station Falleteville, 1988. 88p p. (Series Bulletin).

WORMBASE. Banco de dados sobre Biologia e Genômica de C. elegans [página na internet]. EUA: Califórnia Institute of Technology, Cold Spring Harbor Laboratory, Washington University em St. Louis e The Wellcome Trust Sanger Institute. Acesso em: 2014, ago. Disponível em: <http://www.wormbase.org>.

WORMBOOK. THE ONLINE REVIEW OF C. elegans BIOLOGY [página na internet]. Acesso em: 2014. Disponível em: <http://www.wormbook.org>.

YI, W.; ZARKOWER, D. Similarity of DNA binding and transcriptional regulation by Caenorhabditis elegans MAB-3 and Drosophila melanogaster DSX suggests conservation of sex determining mechanisms. Development, v. 126, n. 5, p. 873-881, 1999. 
YOUNG, R.; DAVIS, R. Yeast RNA polymerase II genes: isolation with antibody probes. Science, v. 222, n. 4625, p. 778-782, 1983.

ZUCKER-APRISON, E.; BLUMENTHAL, T. Potential regulatory elements of nematode vitellogenin genes revealed by interspecies sequence comparison. Journal of Molecular Evolution, Springer-Verlag, v. 28, n. 6, p. 487-496, 1989.

ZUCKERMAN, B. M.; JANSSON, H. Nematode chemotaxis and possible mechanisms of host/prey recognition. Annual Review of Phytopathology, v. 22, n. 1, p. 95-113, 1984. 


\section{Apêndice A}

\section{Perfil da CROMATOGRAFia de Troca iônica}

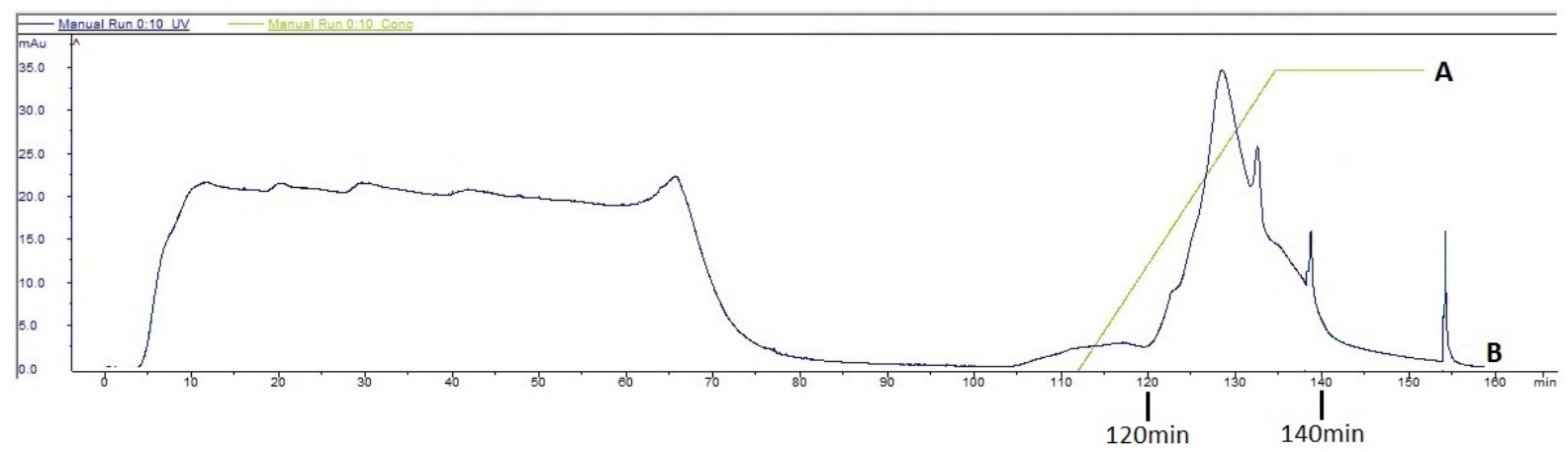

Figura A.1: Perfil da cromatografia de troca iônica para purificação de VTG. A cromatografia de troca iônica foi realizada como descritos em Material e Métodos. Na figura estão apresentados o perfil de absorbância das frações (curva B) e o gradiente de cloreto de sódio (curva A). As frações foram coletadas durante o pico maior de absorbância (120 a 140 minutos). 


\section{Apêndice B}

\section{ÍNDICE DE QUALIDADE DOS reads PROVENIENTES \\ DE RNASEQ}

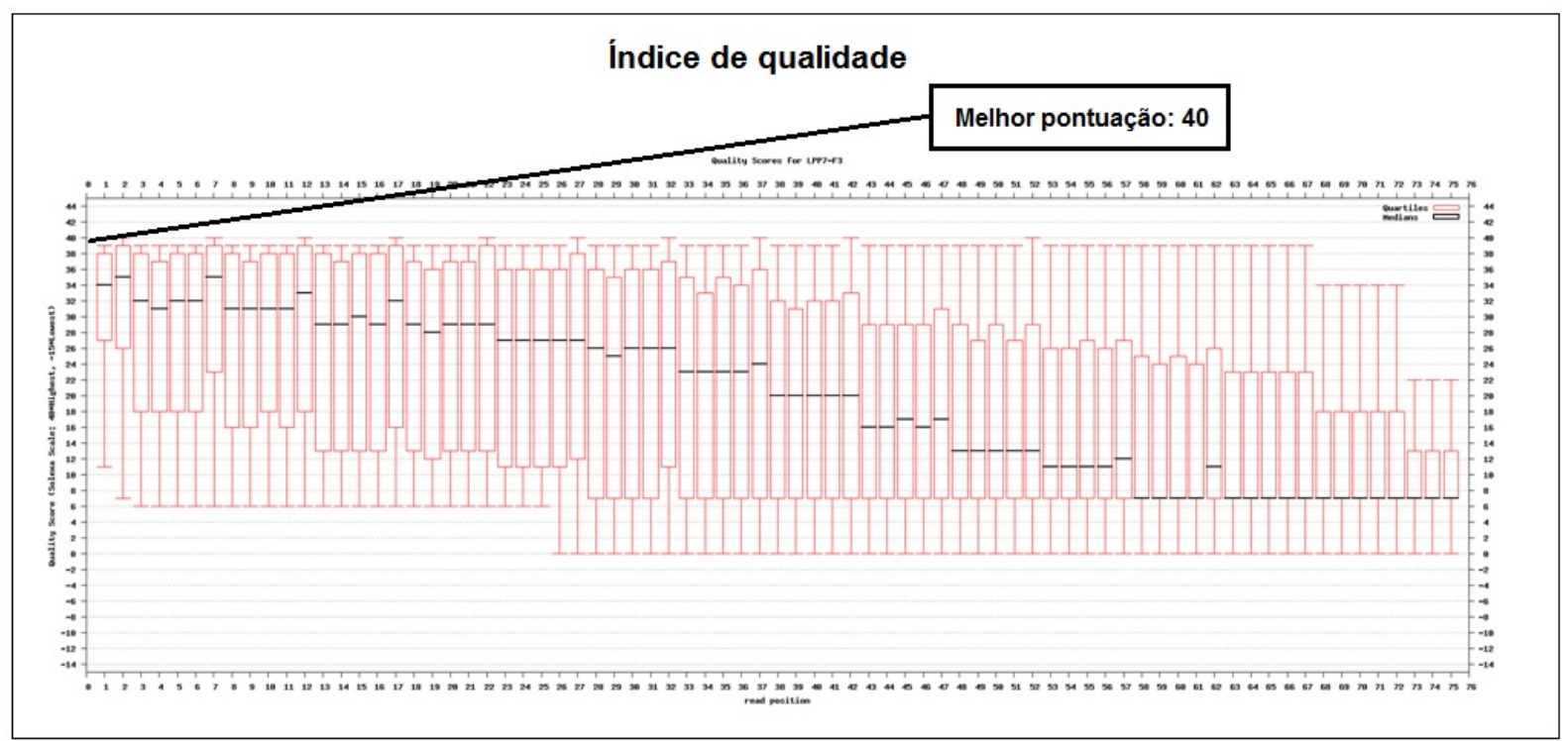

Figura B.1: Índice de qualidade dos reads provenientes de RNAseq. Os reads foram analisados pelo Prof. Dr. Arthur Gruber, do departamento de Parasitologia do ICB-USP. O índice possui uma escala absoluta de qualidade na qual a melhor pontuação é 40. Nota-se que praticamente todos os reads estão abaixo desta pontuação, e a maioria tem uma qualidade muito baixa nesta escala. Portanto, de um total de 42 milhões de leituras, apenas 14 milhões foram aproveitáveis na análise. 